
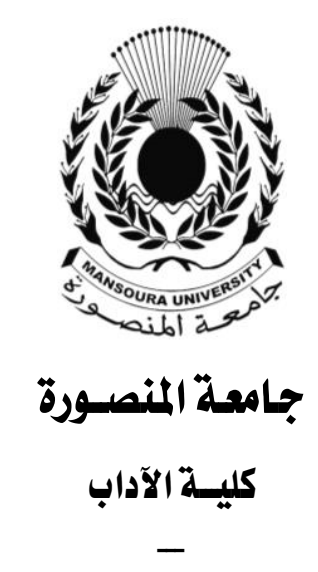

\title{
رؤية الواقع التاريخى فى مسرح فاروق جويدة
}

\author{
إعـــ/د \\ حسيز محمد محمد المربلي \\ باحث لارجة ا لاكتور اه بقسم اللغة العربية \\ كلية الآداب - جامعة المنصورة
}

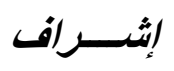

الدكتور/ حمدي منصور الطنطاوي

مدرس الأدب العربي الحديث

كلية الآداب - جامعة المنصورة
الدكتور/ حلمي محمد بلير أبو الحاج

أستاذ الأدب العربي العديث والمقارن المساعد المتفرغ

كلية الآداب - جامعة المنصورة

$$
\text { مجـلة كلــية الآداب - جـامعــة المنصـــورة }
$$




\section{رؤية الواقم التاريخك فك مسرح فاروق جويدة}

حسيز محمد محمد المرسى

تقليـهم:

يعـد التـاريخ وسـيلة فنيـة هامـة يعبـر بها الكاتب عـن الأفكـار المعاصـرة

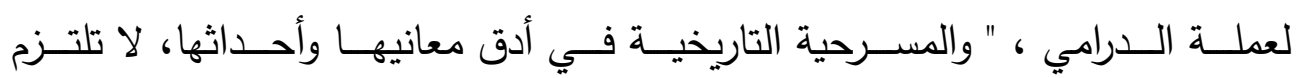

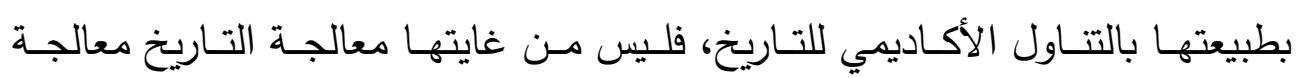

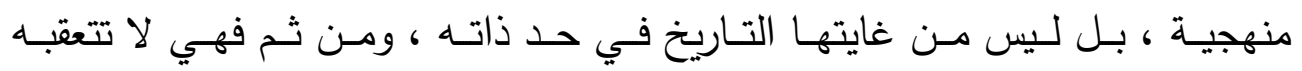

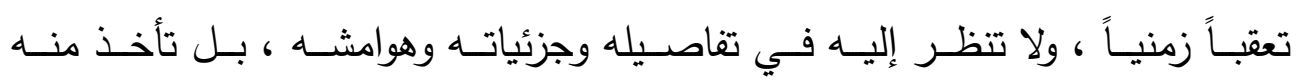

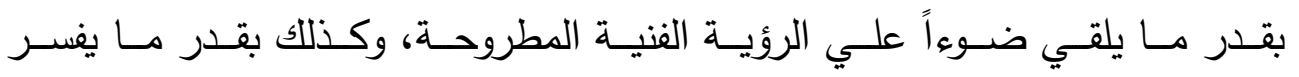

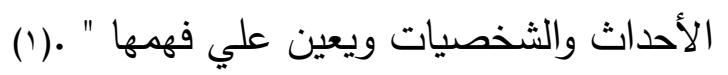

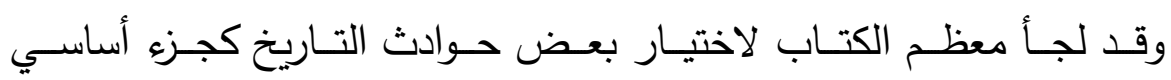

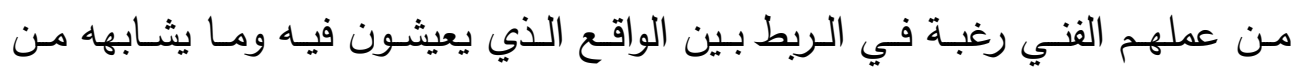

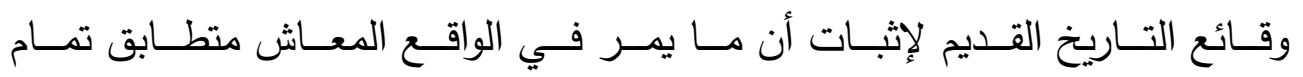
التطابق مسع مـا حدث في الماضـي ؛ لذا فقد اجتذبت الشخصية التاريخيـة كثيراً

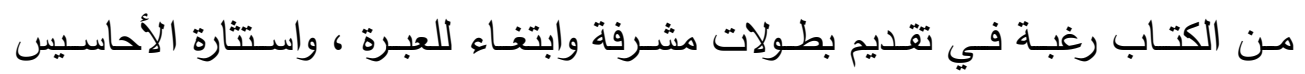

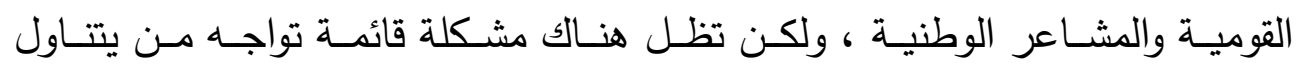

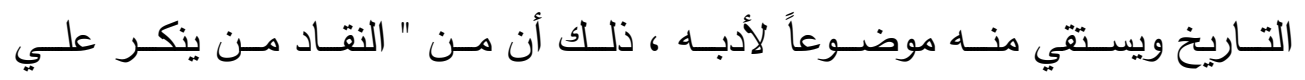

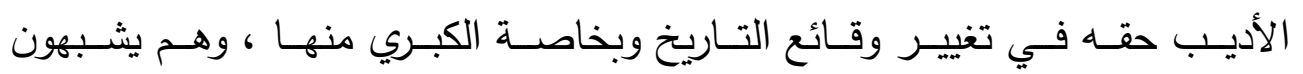

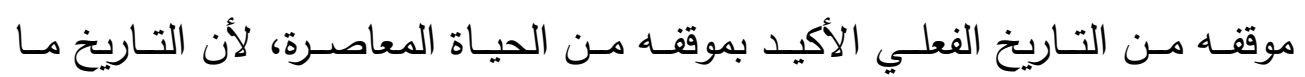

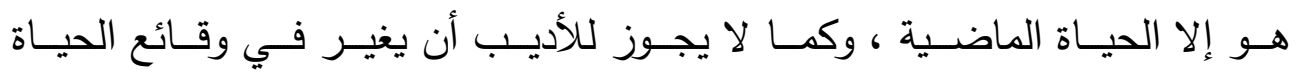
(') محم فتوح أحمد : في المسرح المصري المعاصر . مطبعة عابدين. القاهرة .سنة 9V^ام . صـ 


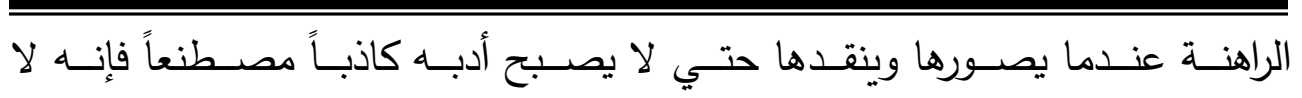

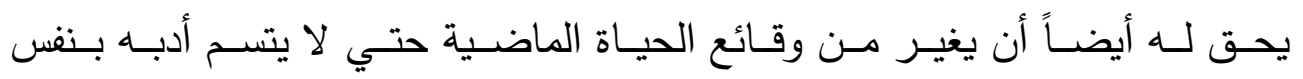

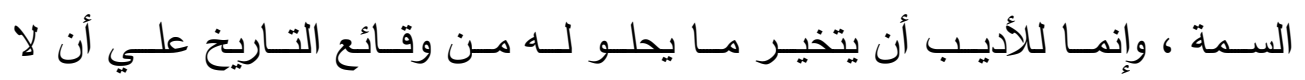
يـؤدي هـذا الاختيـار إلـي قلب حقـائق التـاريخ والعبـث بمنطقـه ، كمـا أن لـه أن يفسر التـاريخ علـي النـــو الـذي يهديـهـ إليـه إحساســه ، وأن يتخيـر مـن بواعـث

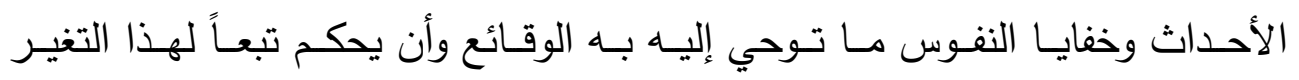
علـي الشخصـيات التاريخيـة الأحكـام التي تتسـق مـع منطـق تفكيـره وإحساســه "

والتـاريخ " معـين لا ينضــب لتجـارب البثـر أفـراداً وأممــاً ، وباسـتطاعة

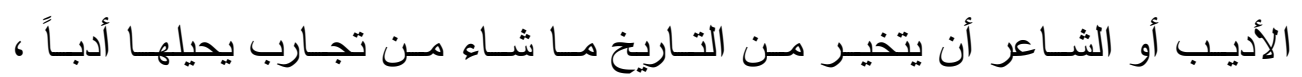

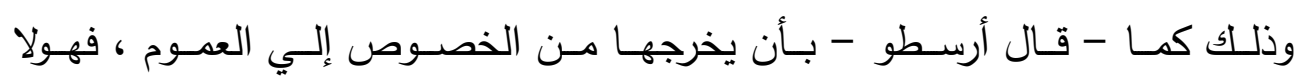
يصـور تجربـة هـذا الرجـل أو ذاك كمـا وقعـــ في التـاريخ ، وإنمــا يصـور تجربـة كل رجل تحـيط بـه نفس الظـروف التي أحاطـ بهذا الرجل التـاريخي أو ذاك ،

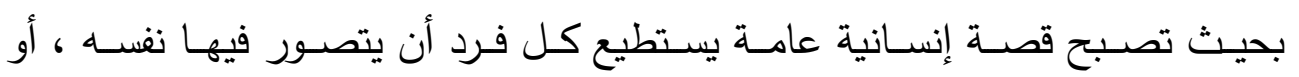

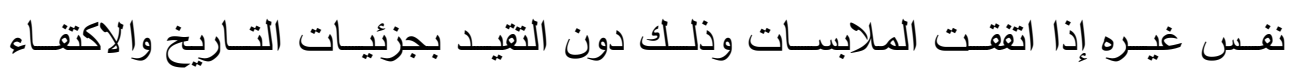
بالخطوط العامة أو القيم الإنسانية الثابتة ". (r) ولـذا فإنتـا نعنـى بدراسـة رؤيـة الواقـع التـاريخى فـى مسـرحيات فـاروق جويـدة الثـعرية ،وذلـك مـن خـال عملين هـامين وهمـا: الـوزير العاشـق - دمـاء على أستار الكعبة. وفيما يلى عرض لهذين النموذجين:

(1) محم مندور : المسرح.نهضة مصر للطباعة والنشر والتوزيع.القاهرة.سنة91919 م. صـ V. 1 ،

(Y) محمد مندور : الأدب ومذاهبه.نهضة مدصر للطباعة والنشر .ط ثانية.سنة $190 \mathrm{~V}$ م . صـ II ، 


\section{النموذج الأول : الوزير العاشق : فاروق جويلدة *}

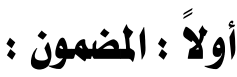

إن المسـرحية التي نحـن بصــدها تعتمـــ " علـي إقامـة تـوازٍ بـين حيـاة

ولادة لابـن زيـدون وتفانيهـا في حبـهـ وبـين طــوح الثـاعر ورغبتـهـ الحـارة فـي تسـلق كرسـي الـوزارة ، الـذي يـؤدي في عصـر الضـعف العربـي والحكـام البلهـاء

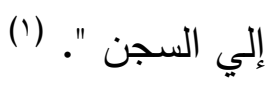

والمسـرحية تبـدأ بـالراوي " أبـو حيـان " الـذي يقـف علـي خشـبة المسـرح ويمهد لأحداث المسـرحية ، ثم بعـد ذلك يـدخل الـوزير " ابـن زيـدون " الـذي يقـام

(*) هـو فـاروق جويـدة مبـارك ، ولـد فـي العاشـر مـن فبرايـر عـام خمسـة وأربعـين وتسـعمائة

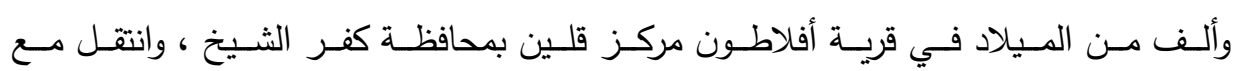

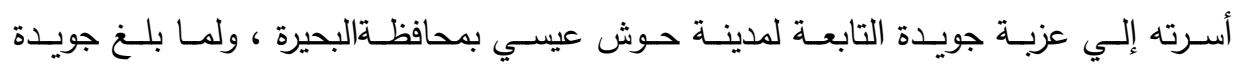

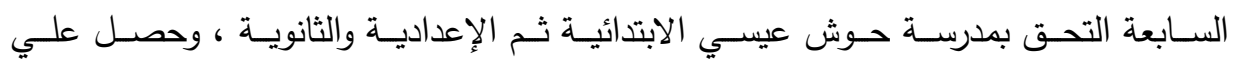

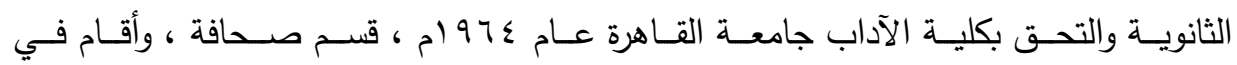
تلك الفترة بحي عابدين إلي أن تخرج عام 971 ام .

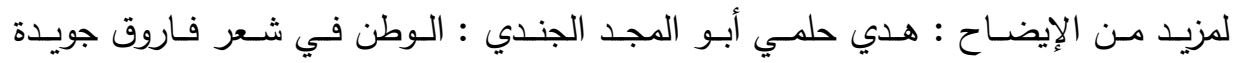

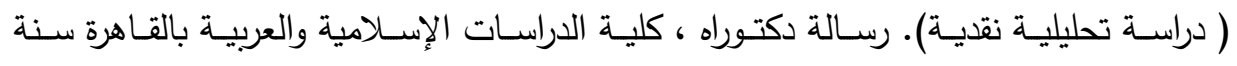

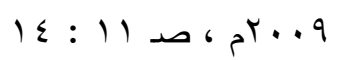

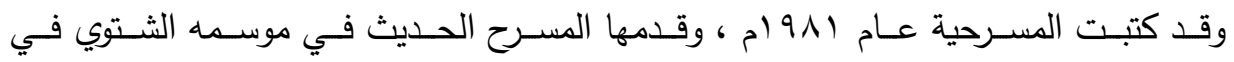

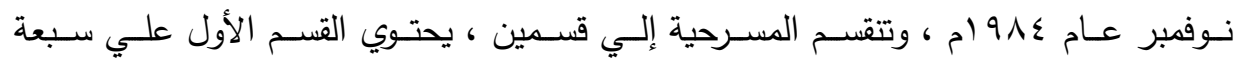

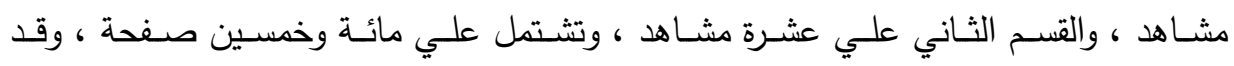

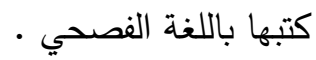

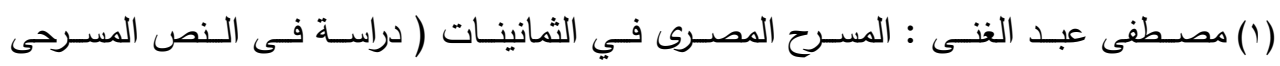

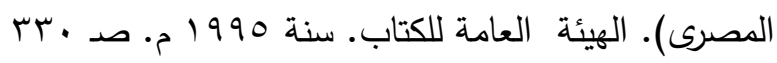


لـه الاحتفـال بتعيينـهـ وزيـراً للدولـة ، ويقف حولـه الثـعراء يمدحونـه مـن كل جانب ، ويشتي علـيهم " ابـن زيـدون " ، ثـم ينتقـل بنـا المشـهـ إلـي بيـت " ابـن زيـدون " حيـث تـدخل عليـه حبييتـه وملهمتهـه " ولادة " ملكـة الأنـدلس التـي سـقط عرشـها يتقــدمها زيـاد ـ ويسـدور الحـديث بــين "ابـن زيــدون" و " ولادة " ، ويفصـح كـل

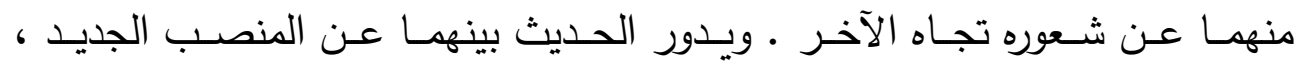

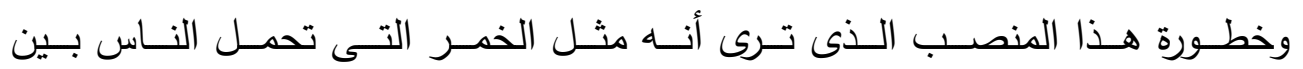

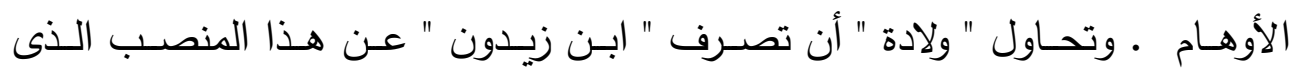
ترى فيـه نهايتـه ، ولكنـه يـرفض طلبها ، ويخبرهـا بأنسه سـيموت حتى تبقى مـآذن قرطبـة ، وتتركـهـه " ولادة " وتخـرج غاضـبة ، ويسـتمر " ابـن زيـدون " فـى حديثـه

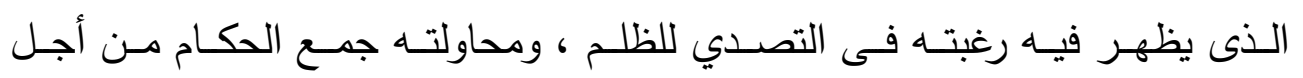

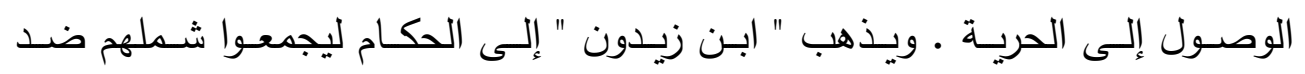

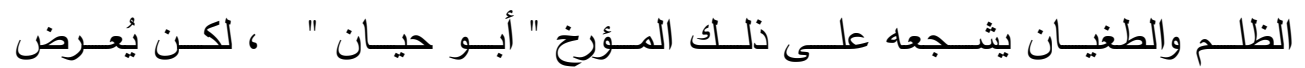
الملوك عن كلام "ابن زيدون" ل

وفـي المشـهـ الرابـع فـي حديقـة بيــت " ابـن زيـدون " تجلس وصـيفة " ولادة "'" زهــراء" ، وخــادم " ابـن زيــدون " " زيــاد " يتحـــثان حــول حـال النــاس

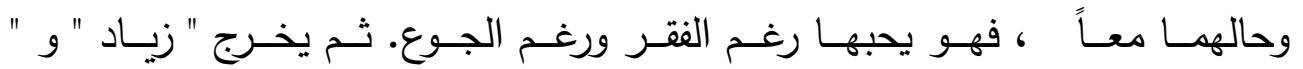

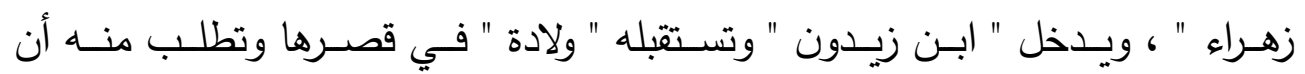

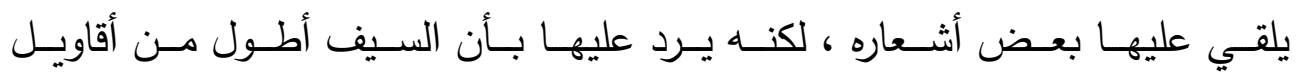
اللسـان ، ويسـتمر الحديث بينهمـا حتـي يخبرهـا بـأن الأميـر "المعتمــ" طلب منـهـ

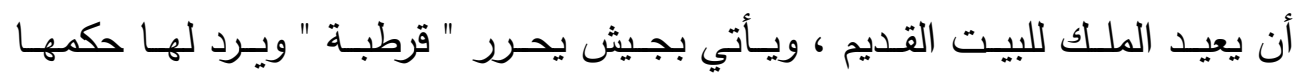
الأندلسـى حتـي تعـود الوحـدة الكبـرى مـرة أخـري ، فتتـور عليـهـ "ولادة " وتخبـره

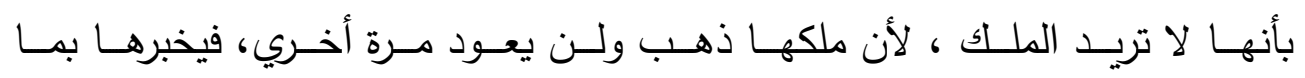

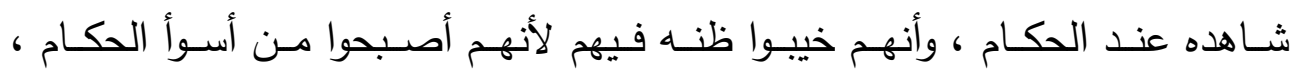




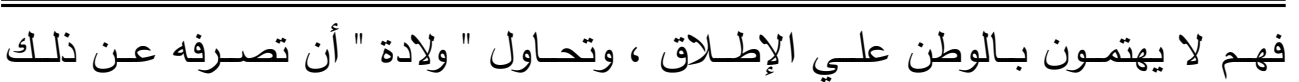

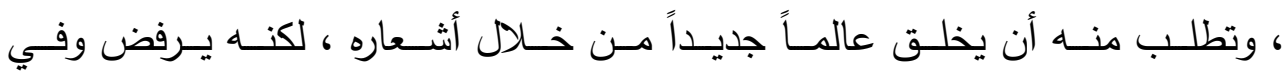

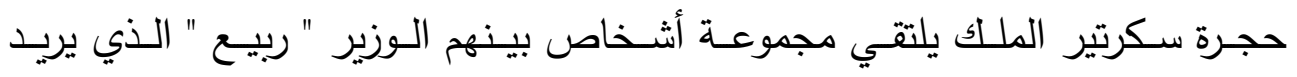

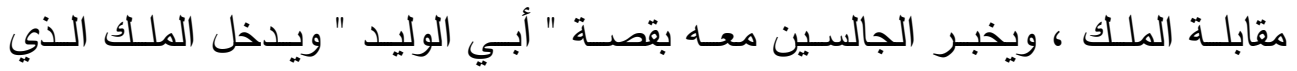

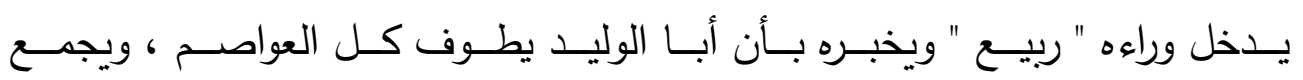

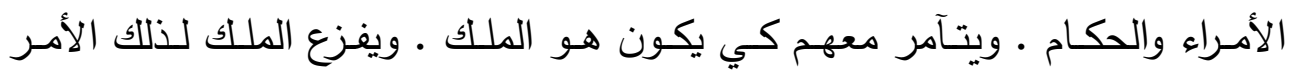

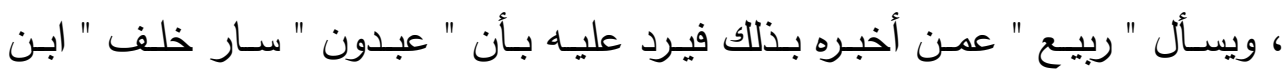

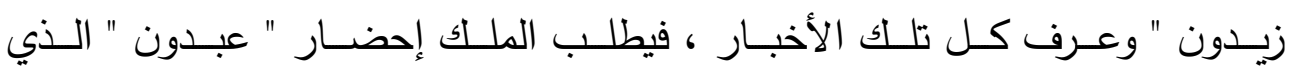

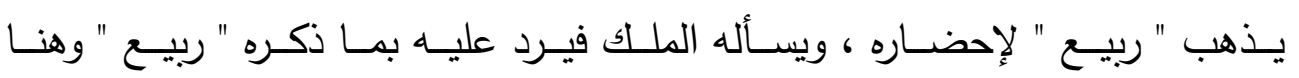

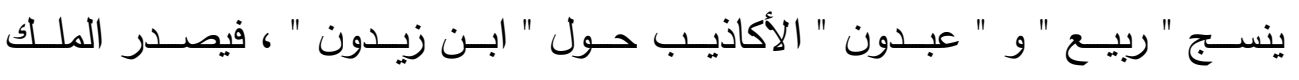

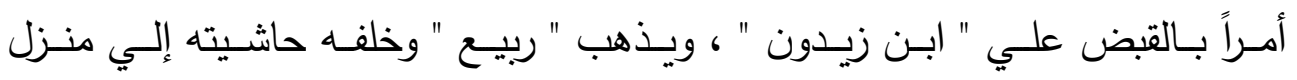

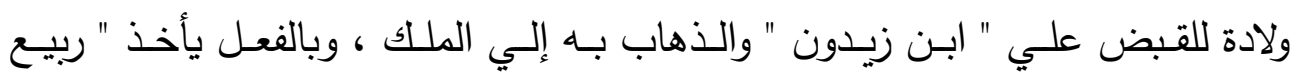

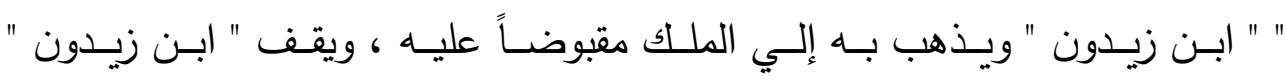

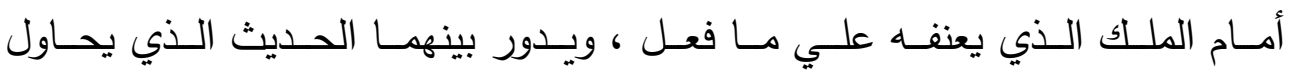

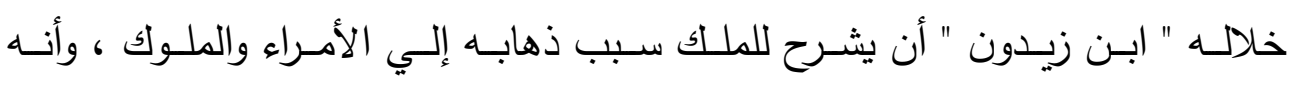

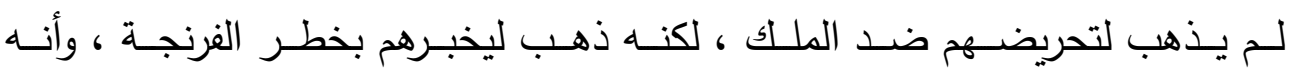

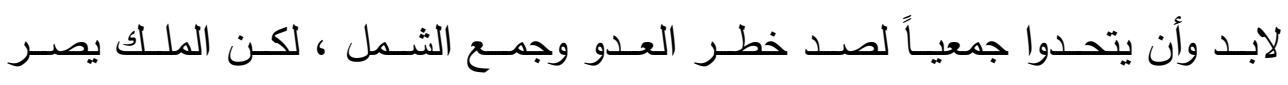

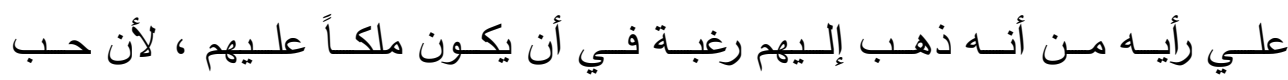

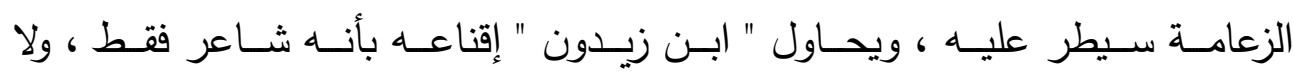

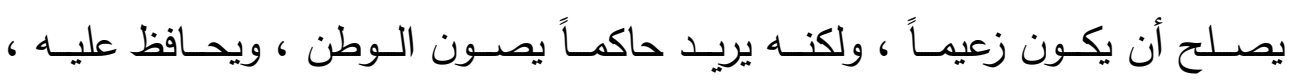

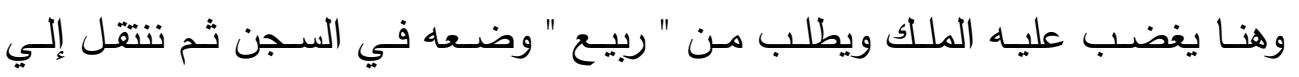

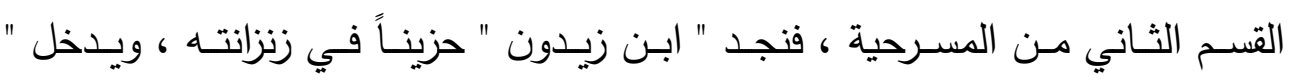

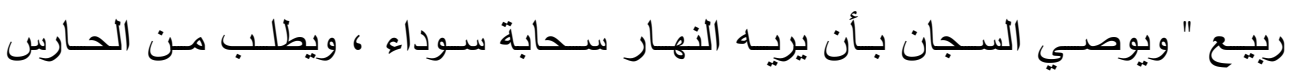

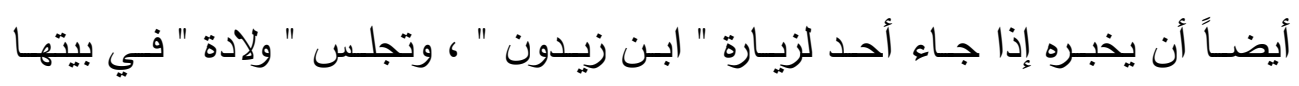


حزينـــة باكيــة ومعهــا وصـــفتها " زهـــراء " و " زيــادة " ، وتقــول " ولادة " بــأن السـفهاء أصــبحوا حكـام الـبلاد ، وأن الأطهـار ذهبـوا إلـي الســون ، وتـدور "

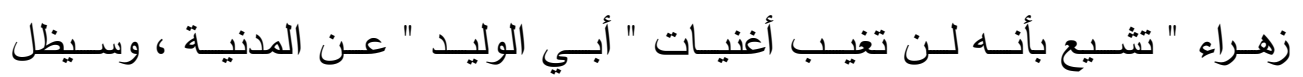
شـاعرها • وتســأل " ولادة " "زهــراء" عمــا يقــول النــاس ، فتخبرهـا " زهــراء " بـأن

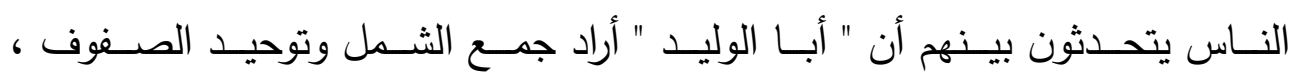

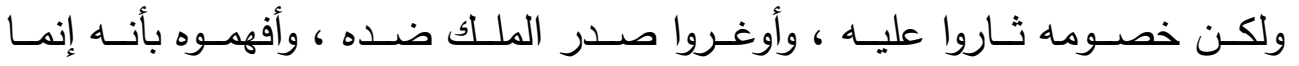

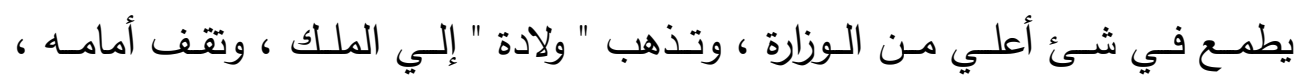

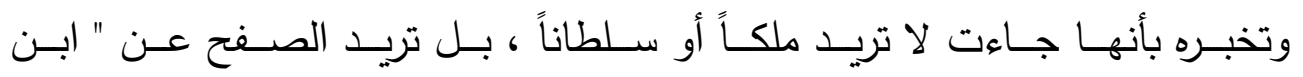

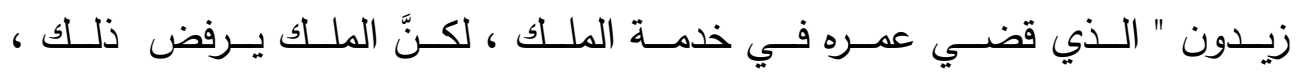
ويعتقـــ أن تلـك الخدعـة يـراد بهـا وصــول "ولادة" إلـي كرسـي الحكـم ، وتتركـهـ " ولادة " وتعـود إلـي قصـرها حيـث يـدخل عليهـا " ربيـع " وهـي حزينـة في مجلسـها

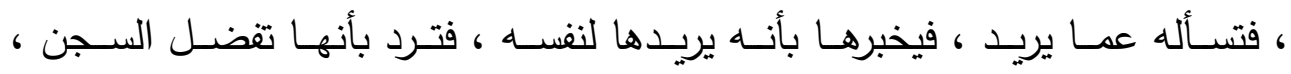

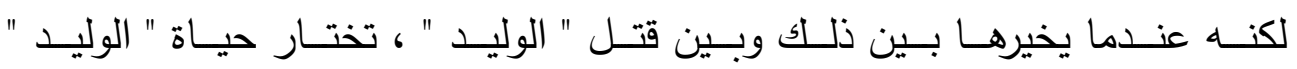
ويـذهب " ربيـع " لابـن زيـدون " ويخبـره بـأن ولادة سـلمت لـه نفسـها ، فينهـار " " ابـن زيـدون " عنـدما يسـمع ذلـك . وتسـتمر الأحـداث إلـي المشـهـ الثـامن حيـث قصـر " ولادة " وهـي تجلس مـع " أبـي حيـان " ويسـألها عـن حسال " أبـي الوليــ "

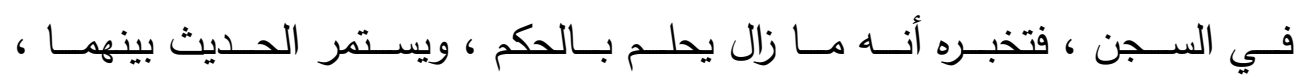

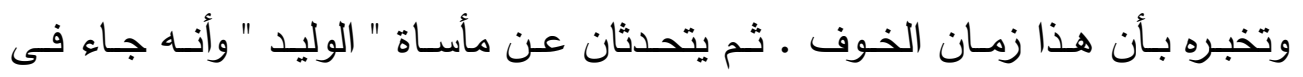
زمـن لـيس لـه ، فقـــ عـاش يـؤمن بتوحيـد الصـفوف مـن أجـل أن يبقـى ديـن الله

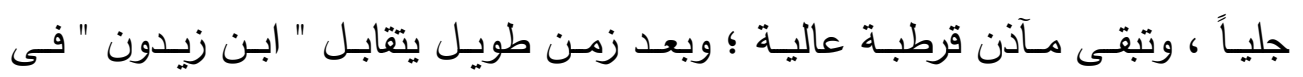

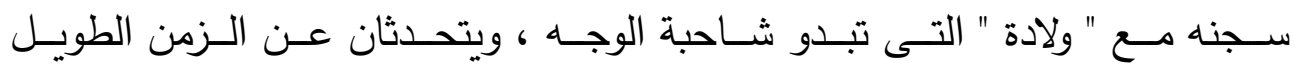

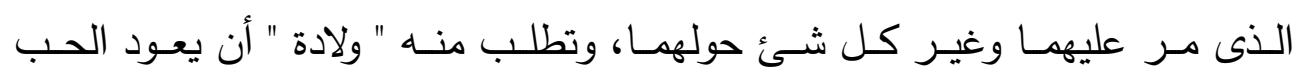

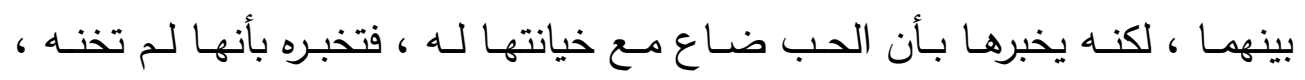

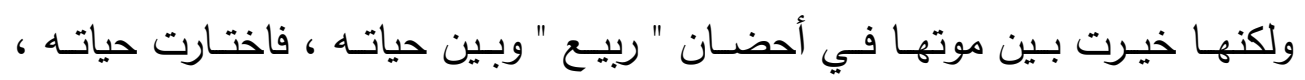




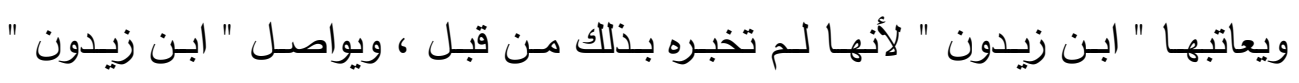

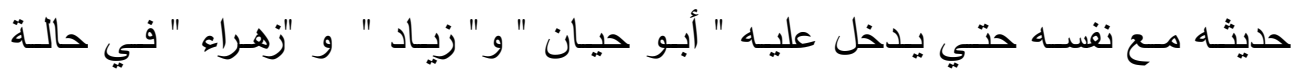

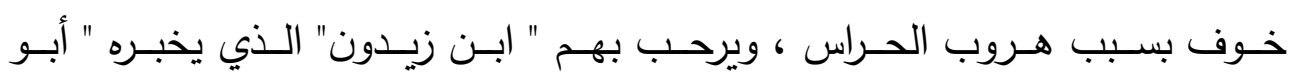

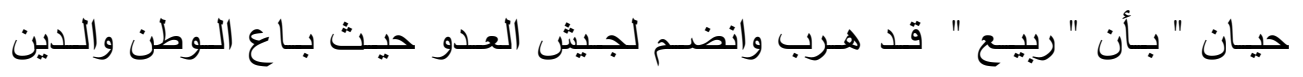

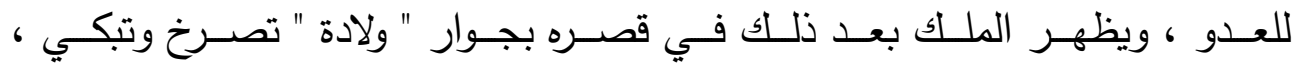

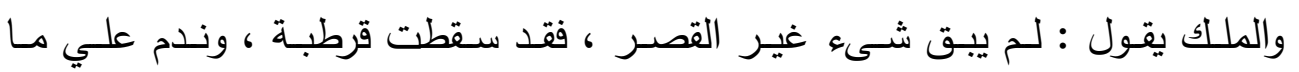

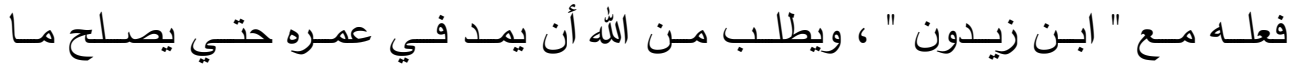

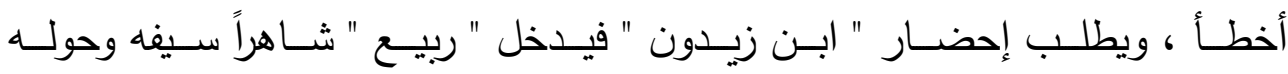

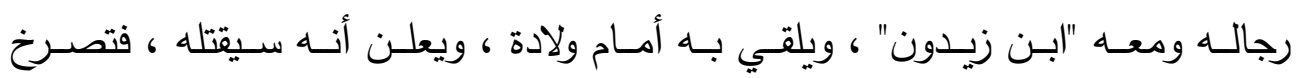

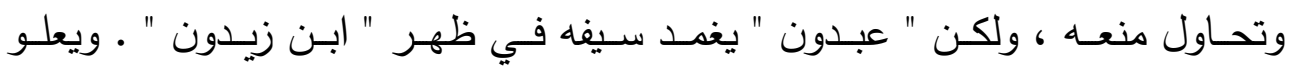

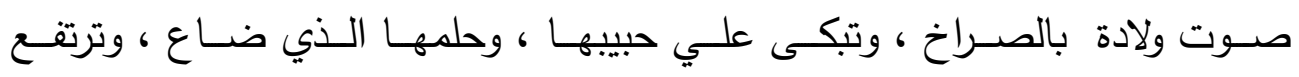

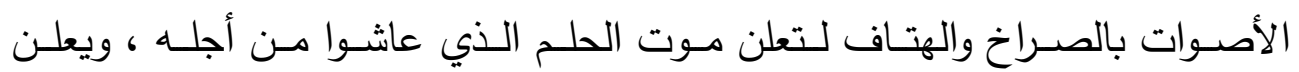

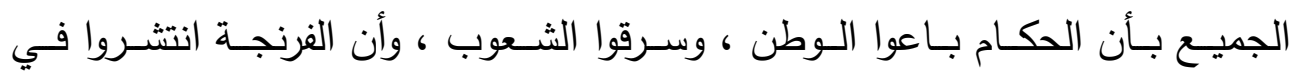

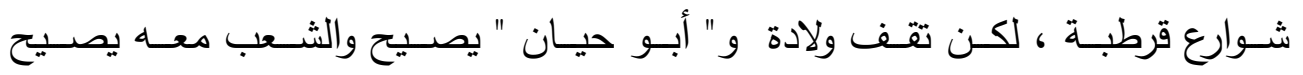

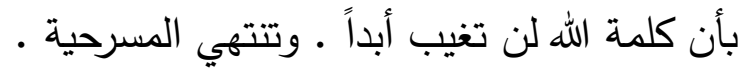

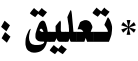

فهذه المسـرحية التـي يتـــاول فيهـا " فــاروق جويــة " رقعـة مـن تاريخنـا

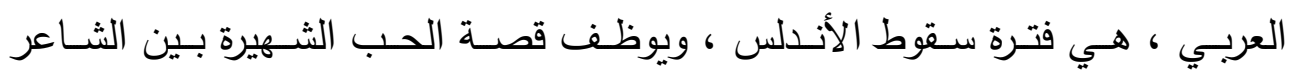

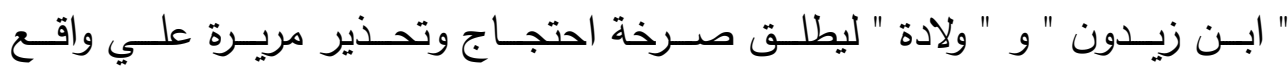

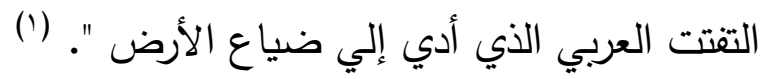




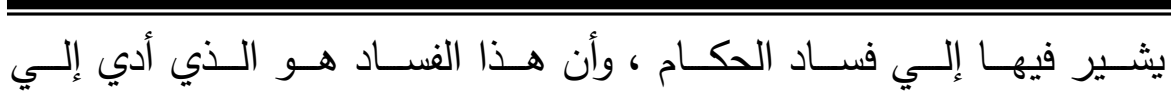

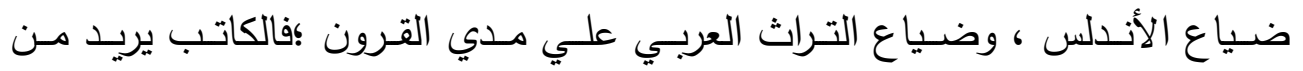

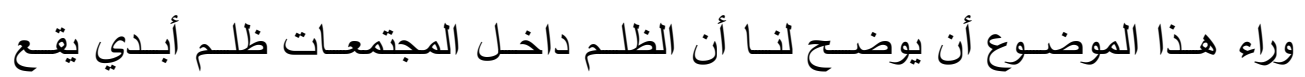

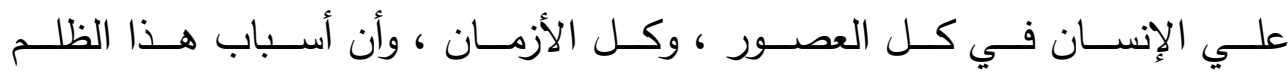

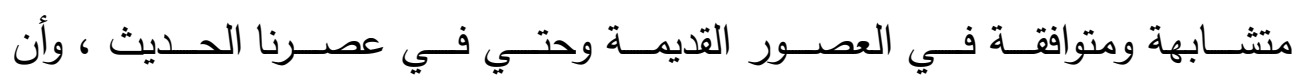
السـبب وراء ضـياع الأوطـان إنــا يرجـع إلـي ظلـم الحكـام ، وفسـاد الحاشـية .

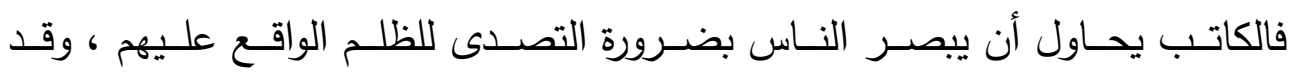

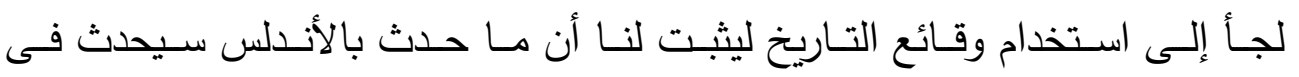

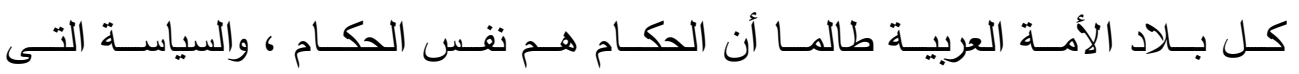

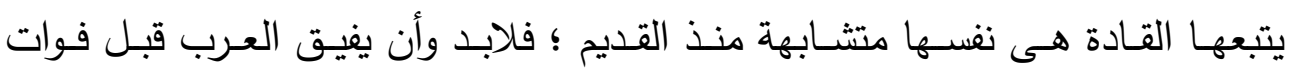

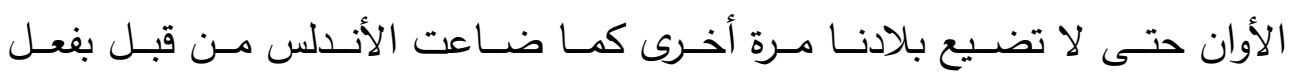

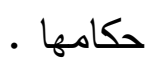

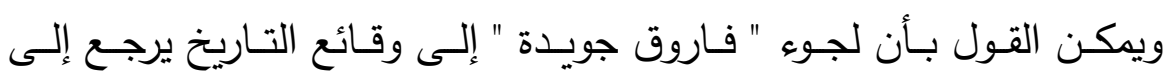

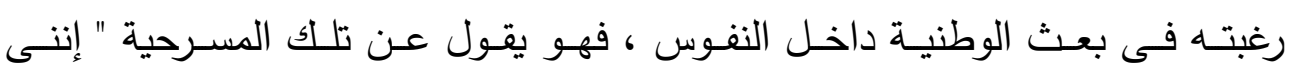

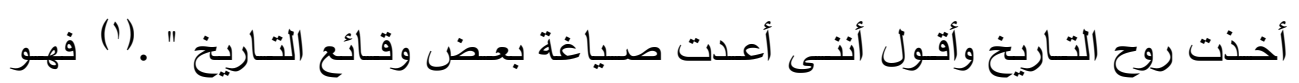

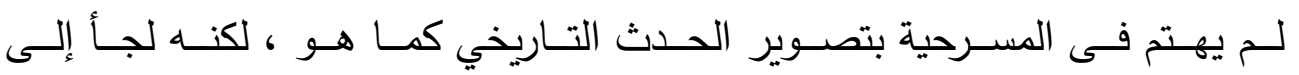

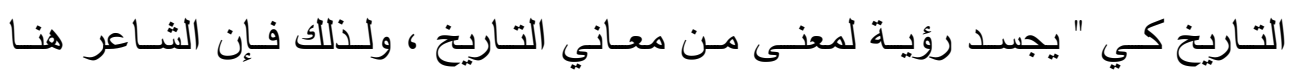

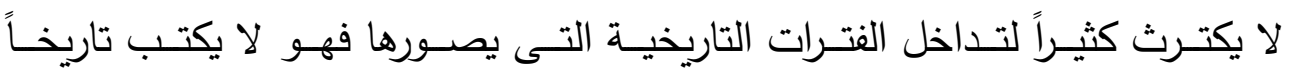

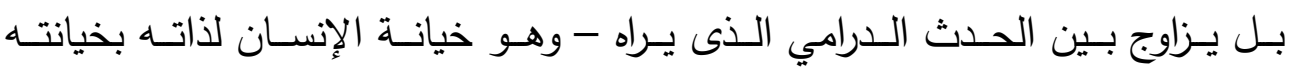




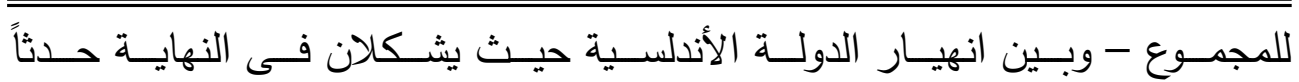

واحداً". ( ) (ل)

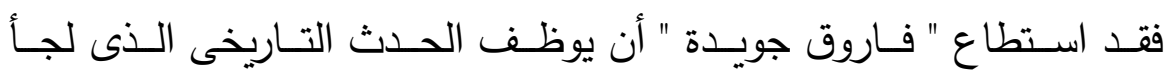

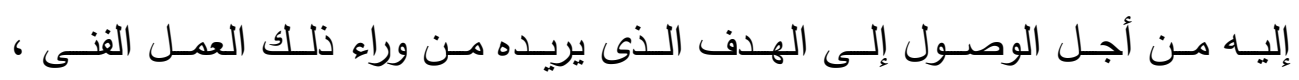

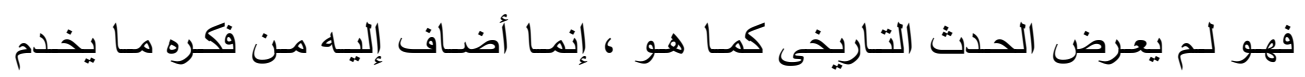

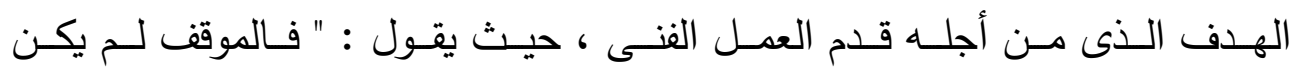

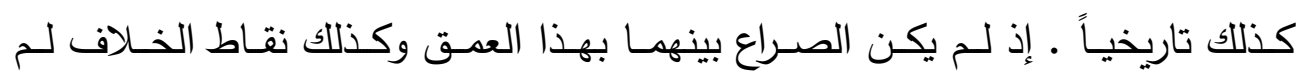

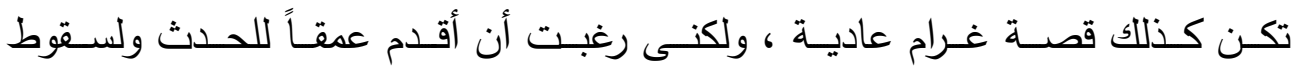

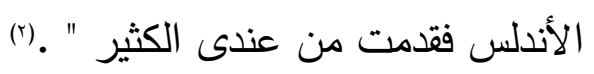

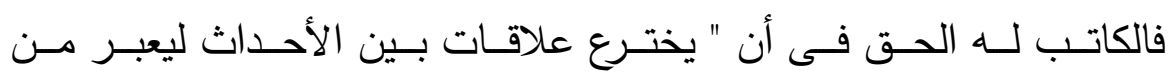

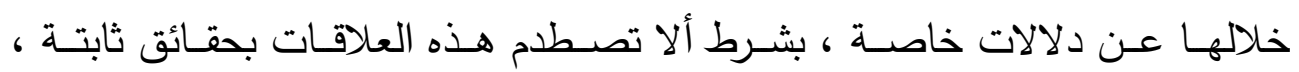

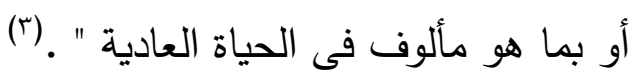

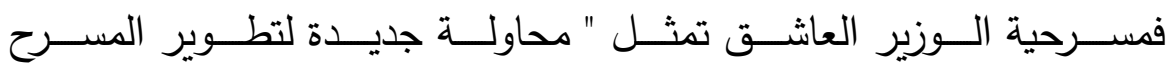

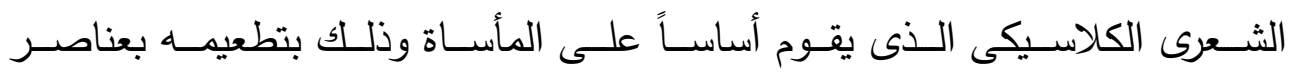

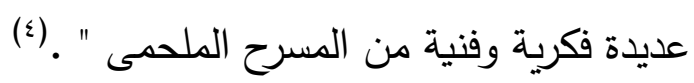

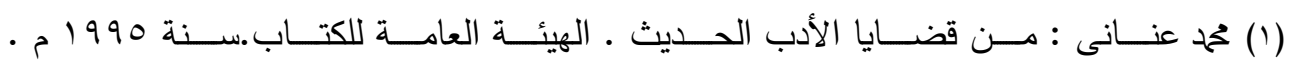
صدا

(r) مصــرى عبــــ الحميــحنورة : الأسـس النفــية للإبـــاع الفنـى فـى الثــعر المسـرحى . صدVץ

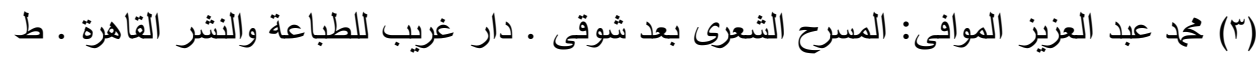

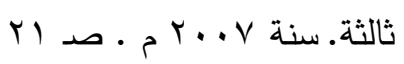

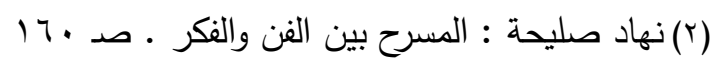


ومسـرحية " الـوزير العاشـق تعكس فكـرة الصـراع بـين السـيف والكلمـة ،

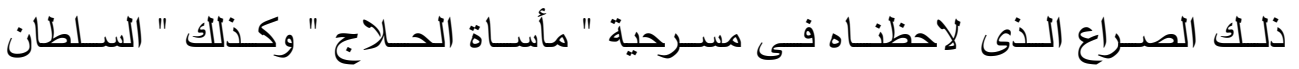
الحسائر " ، لكـن فـى مسـرحية " الــوزير العاشـق " يحــث اخـتلاف فـى شـكل

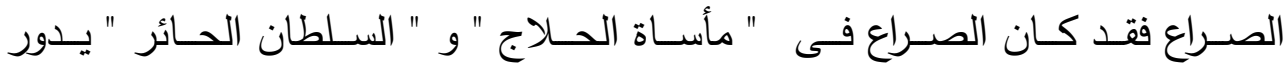

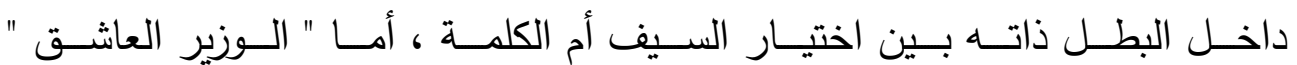

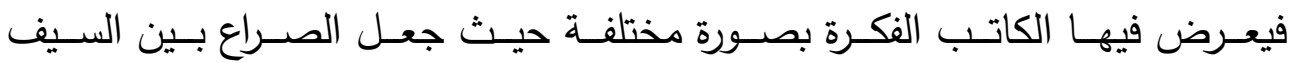

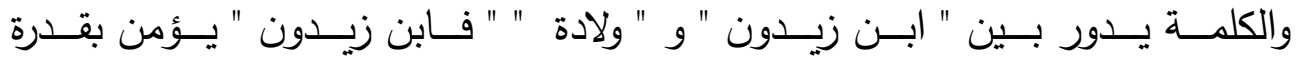

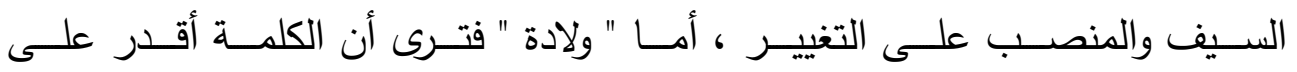

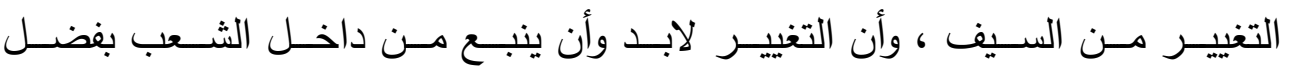

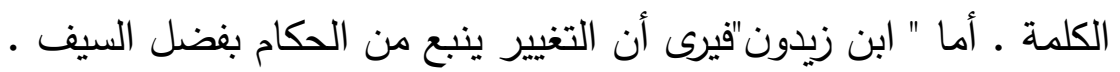

\section{ثانياً : الشخصيات :}

إن الشخصـية المسـرحية " أرهـــ ركـن مـن أركــان الــص المسـرحى لأن

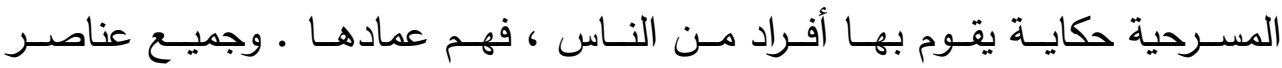

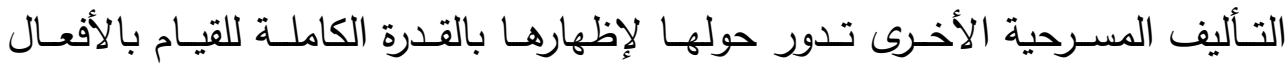

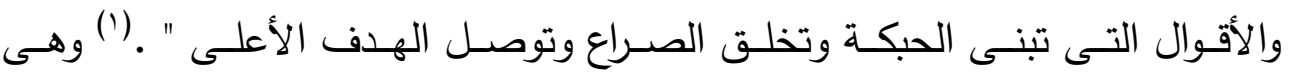

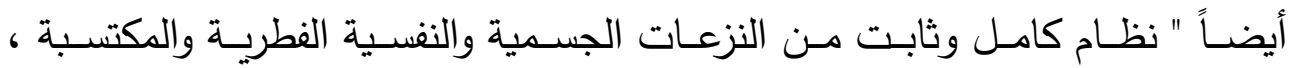

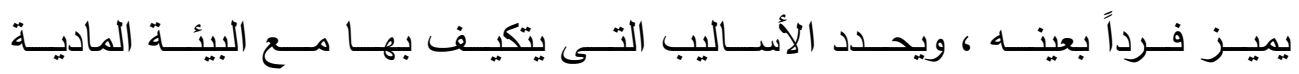

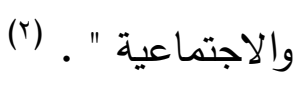

( () فرحسان بلبـل: الــص المسـرحى ( الكلمـة والفعـل ).منشـورات اتحساد الكتـاب العرب.دمشـق.

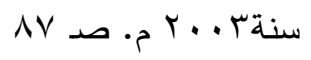

(r) صلاح حسنى عبد العزيز : حمحد عبد المجيد حلمى كناقد مسرحى .الدار القومية للطباعة والنشر • سنة 
فـإذا نظرنـا إلـى الثخصـيات فـى مسـرحية " الـوزير العاشـق " نجــها

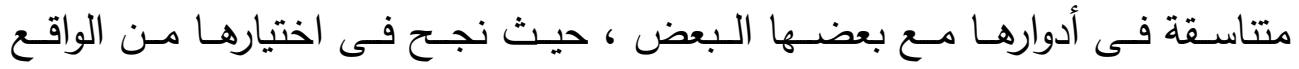

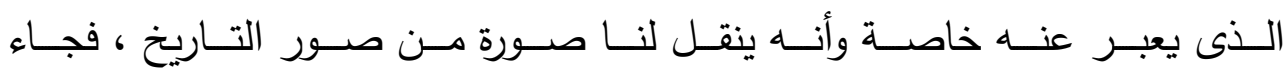
بشخيات حقيقية وليست من واقع الخيال .

فنجـ فـى المسـرحية تتويعـاً ، منهــا الرئيسـية المحوريـة ، ومنهــا الثانويـة

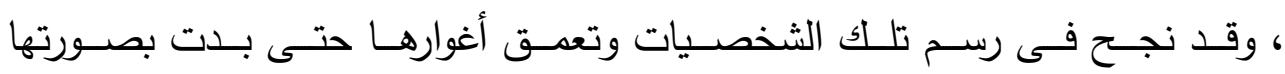

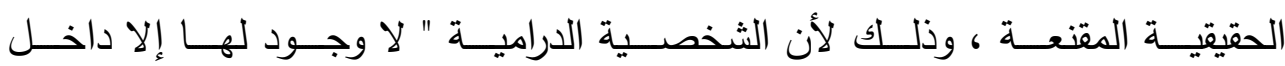

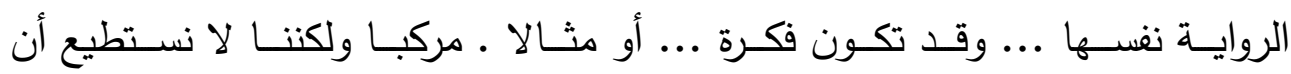

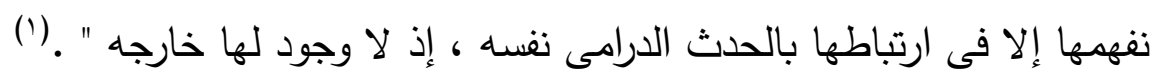
وفيما يلى عرض لنماذج من هذه الثخصيات :

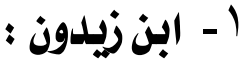

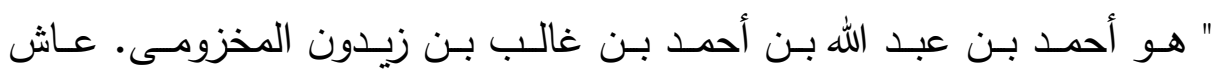

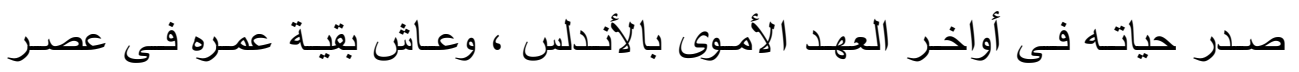

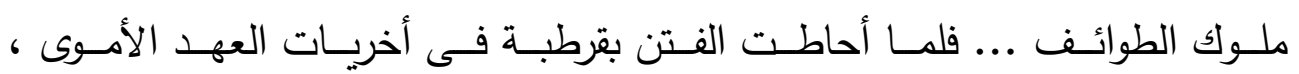
كـان مـن الزعمـاء الثائرين على الفسـاد ، ومـن المسـاعدين فـى تقـويض السـلطة

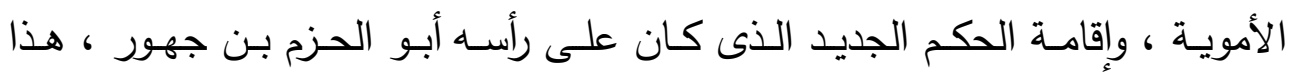

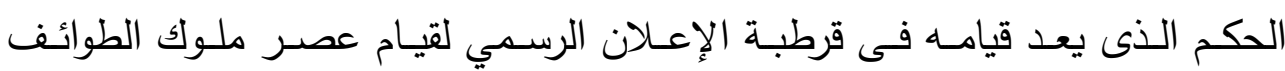
(广). . "...

(') أمير سلامة: الثخصية والنمط فى الدراما. مجلة الفنون ـ السنة الأولى .العدد التاسع.يونيو.

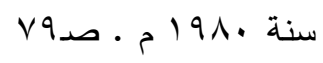

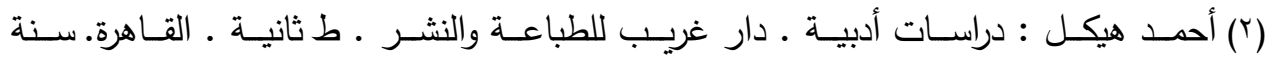

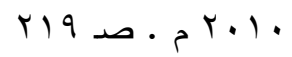




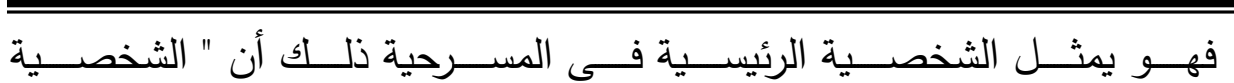

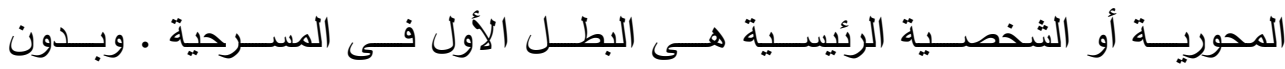

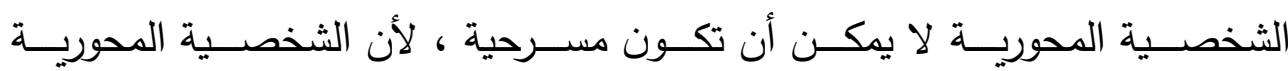
هى الإنسان الذى يخلق الصراع ويجعل المسرحية تتحرك إلى الأمام...."." (1)

فهو يـؤمن بـدور المنصـب والسـيف فـى التغييـر ، بـالرغم مـن كونـه شـاعراً ،

والثــاعر وســيلته الأساسـية هــى الكلمــة ، فهـو منشــل " بقضــية الأرض ، قضـية الدولـة العربيـة الإســلامية التـى يتهـددها الغـزاة، وهـو يحسـاول إيصــال رؤاه إلـى الحكـام علهم يلتفتـون ... وهـو بطـل مـن نـوع جديــــــبـ طبيعـة الصـراع

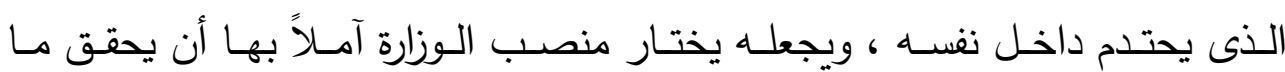

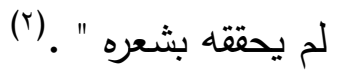

\section{فهو يقول عن المنصب والسيف :}

ابن زيدون : ماذا يجدى صوت الثاعر ؟

لا يجدى وسط الطلقات ...

يحيا ليقاتل بالكلمات

لكن السيف سيخرسها ...

( ) لاجـوس آجـرى : فـن كتابــة المسـرحية.ترجمة درينـى خشــبة.دار ســعاد الصــباح.ط

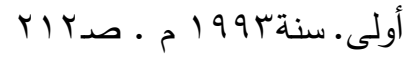

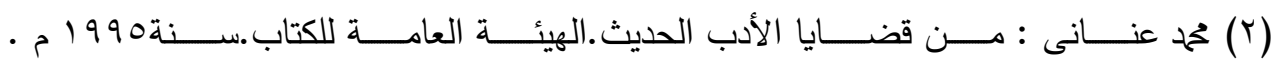
r 


$$
\begin{aligned}
& \text { أعرف و الله سيخرسها .. وسيخرسنى ... } \\
& \text { أحياناً يحمينا السيف } \\
& \text { ما أثقل أن يصبح سيف } \\
& \text { فوق الكلمات } \\
& \text { المنصب يحمى أحياناً ... }
\end{aligned}
$$

$$
\text { ابن زيدون : الفن يموت مع السجان ... }
$$

والكلمة تسجن فى القضبان

$$
\text { لنتحر ونحن الأحياء }
$$

بالسيف سنحمى الحلم

$$
\text { نصون الأرض ... ونصنع كل الأشياء ...(r) }
$$

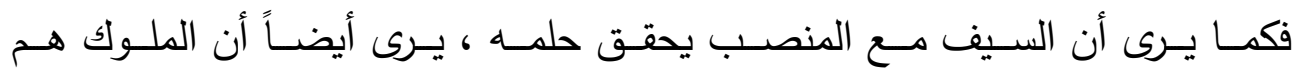

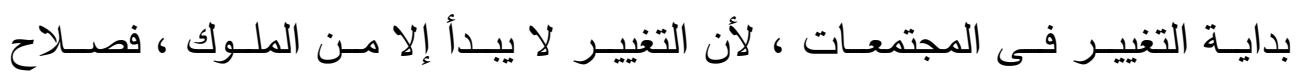

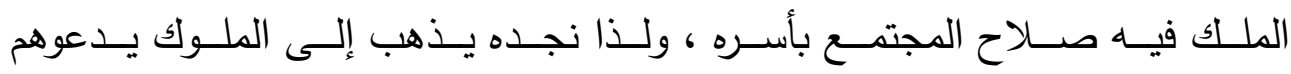
للاتحـاد فـى مواجهـة العـدو لتقـوى جبهـتهم ، ويـدعوهم كـذلك لإصــلاح أحـوال الرعية ويحذرهم من عاقبة التفرق .

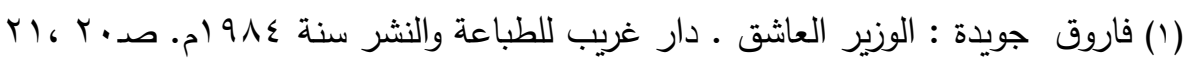

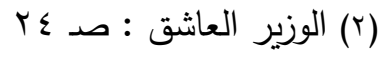


" يدخل ابن زيدون على الملك رقم ( ) وهو يجلس وسط حاشيته "

الواقع العربى يا مولاى ينبئنا بأن

كوارث الدنيا ستلحق بالعرب ...

حرب هنا ...... حرب هناك ....

وزعامة فى كل شبر من ربوع الأندلس ...

لم لا نوحد تحت دين الله كل صفوفنا ...

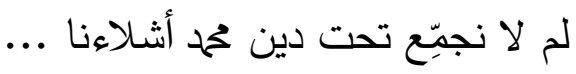

(').... سنضيع يا مولاى

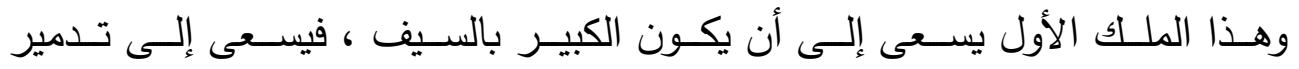

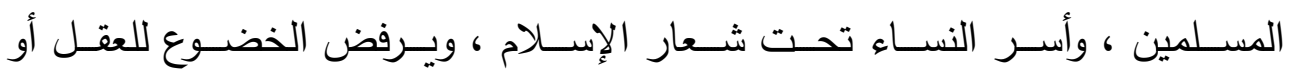

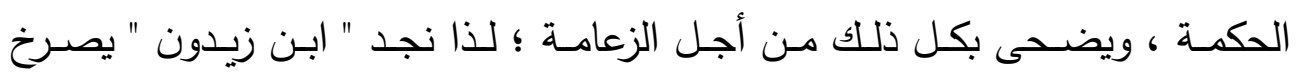

ابن زيدون : فى زمن السفلة والسفهاء

لا صوت لعقل أو حكمة ...

ويحك يا سيف السفهاء ...

قد ضاع زمان الحكماء ... (؟)

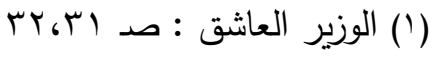

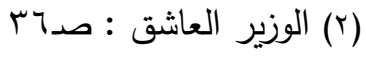




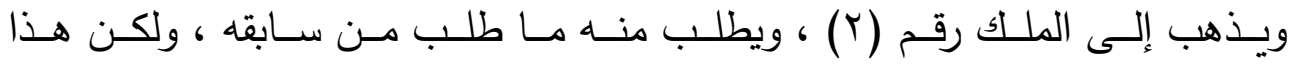

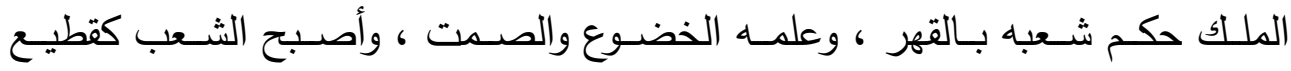

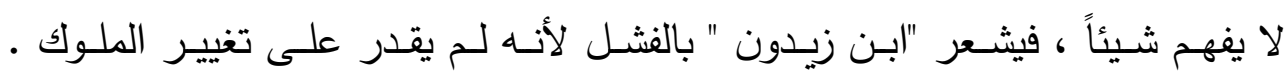

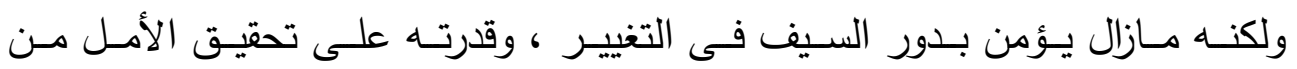

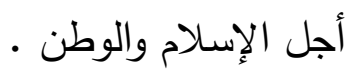
ابن زيدون : هل تقبلين بأن تداس •

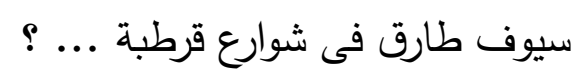
هل تقبلين بأن تضيع الأرض من يدنا ... ؟ هل يصبح الإسلام فى وطنى غريباً ضائعاً ... ؟ هل نترك الأرض الحبيبة للفرنجة ... ؟

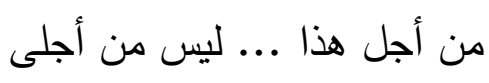
أريد السيف ... والسلطان ()

ويستخل ربيـع " ذهـاب " ابـن زيــدون " إلـى الملـوك ودعـوتهم لتوحيد الصـفوف ،

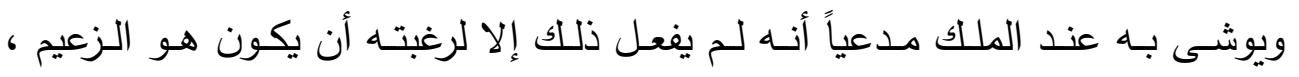

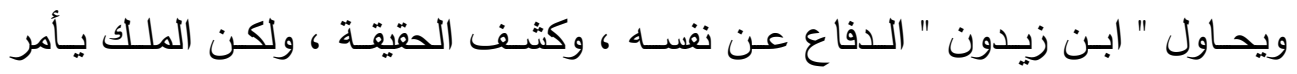

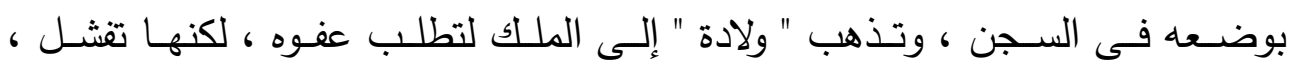

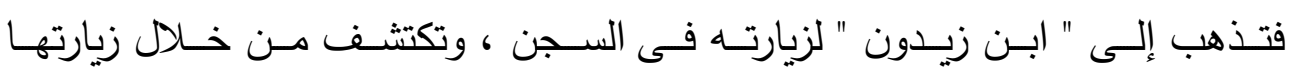

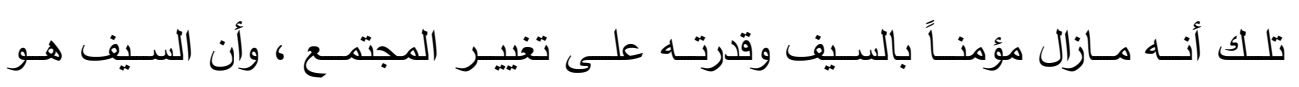

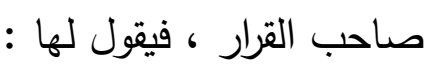
ابن زيدون : من أدخل المسجون فى القضبان ؟ 
من أسكت الكلمات فى الأعماق ؟

من مزق الأطفال فى الطرقات ؟

من باع أصوات الضمائر ... ؟

من يجعل الأحياء موتى ...

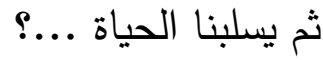

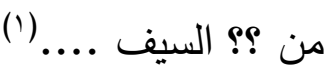

ويـذهب " أبـو حيـان "و " زيـاد " و "زهـراء " إلـى " ابـن زيـدون " فـى

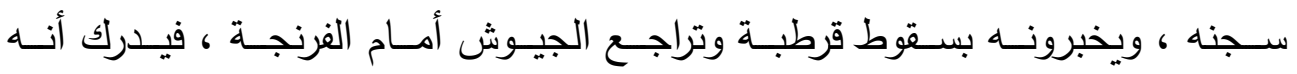
أخطـأ ، ولكن بعـد فوات الأوان ، وضـياع عمـره، وكذللك ضـياع وطنـه ؛ لأنـه لـم

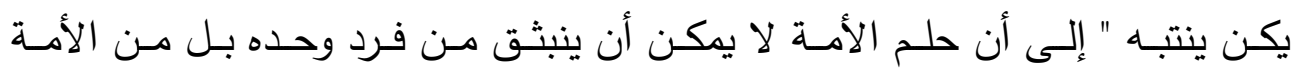
كلهـا ـ ولـو كـان ابـن زيـدون فهم ذلك لمـا كـان هنـاك صـراع بـين السـيف والقلم أو بـين الحـب والواجـب .... ففـاروق جويـدة يطـرح الحــم الفـردى لابـن زيـدون فـى القالــب التراجـــى الكلاسـيكى المعهـود ، ثـم يسـلط مـن داخـل المسـرحية تعليقـاً نقدياً قويـاً على الموقف الفكرى الذَى تمثلـه التراجيديا مـن خـلال الموقف الفكـرى الــى تمثلـه العناصـر الملحميـة ، والـذى يصـبح رمـزه وشـعاره جملـة ولادة

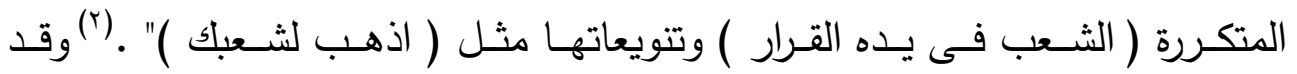

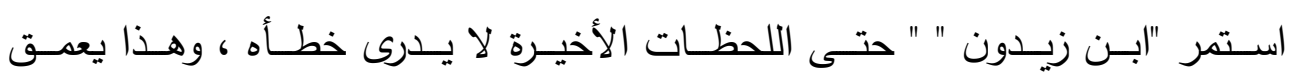
(r) المأساة إلى أبعد الحدود " ل 


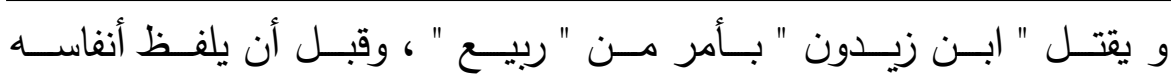

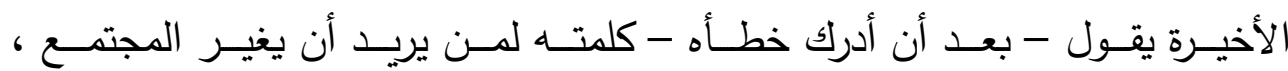

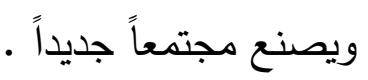

$$
\text { ابن زيدون :.......................... }
$$

لا تصنعوا الأحلام فى ظل الملوك ....

الحلم فى الطرقات نصنعه وبين الناس

الحلم يغرس فى حقول القصح

في صوت المصانع ...... (')

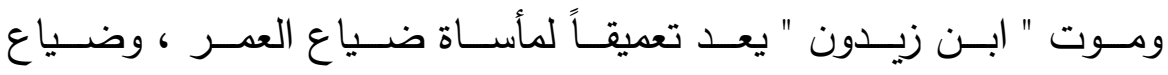

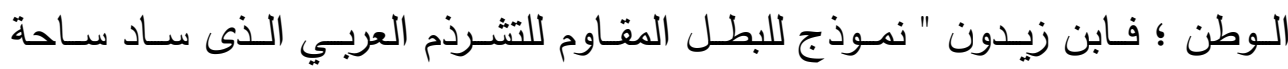

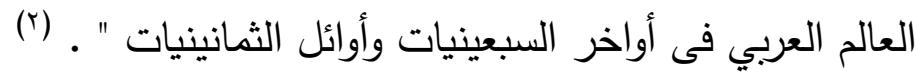

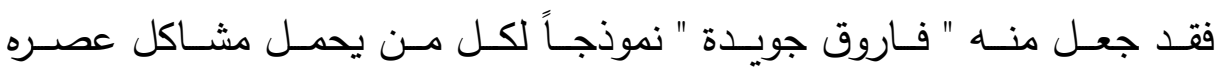

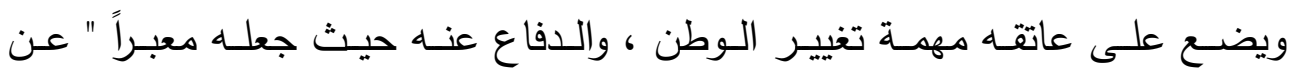

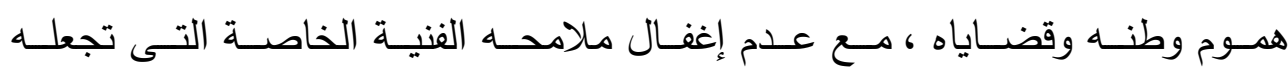

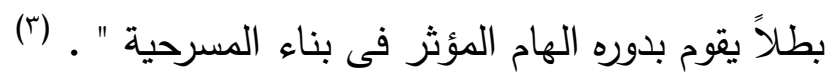

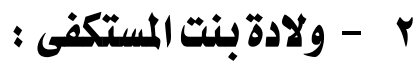

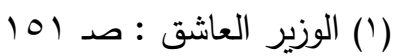

(ץ) حسين على محمد : البطل فى المسرح الثعرى المعاصر .الهيئة العامة لقصور الثقافة. سنة

$$
\text { V. } 1991
$$

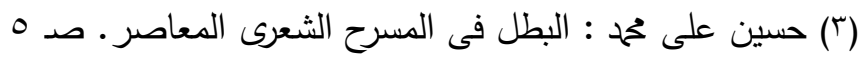




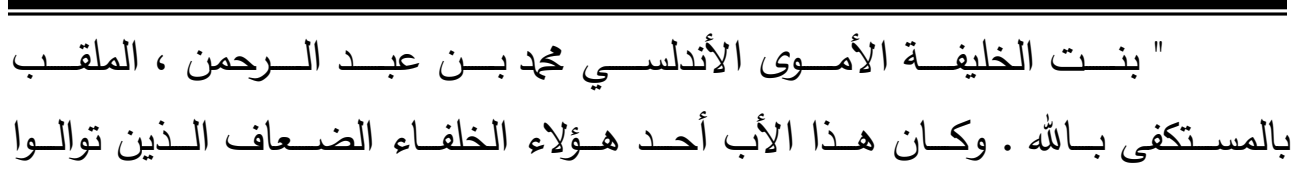

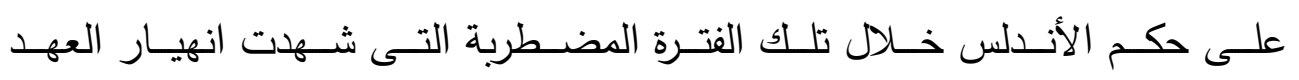
الأموى ثم قيام عصر الطوائف ..". ( ) وقد جعل المؤلف منهـا رمـزاً حيـث يقـول عنها " فقـد كنـت حريصـاً على أن أظهرهـا فـى شـكل قديسـة ، حتـى عنـدما سـقطت فـى المسـرحية فقـــ سـطـت

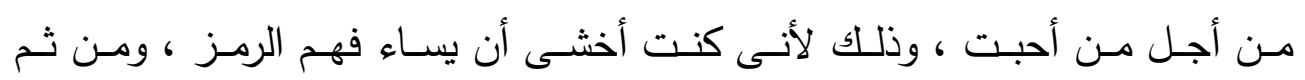
فأنا تعاطفت معها فى المسرحية .... " . (r) فقـــ كانــت ولادة فـى المسـرحية تـدافع عـن الكلمــة ، ممــا يجعلهـا فـى

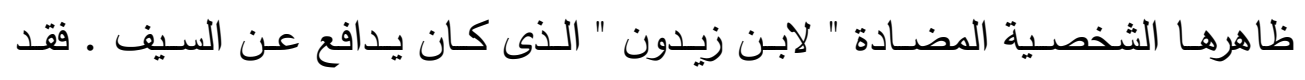
كانت ترى أن الكلمة وسيلة من وسائل التغيير • ولادة : أنا لا أريد الآن شيئًا من حكايات الملك

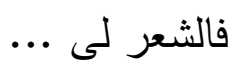
والملك للك ... تعال الآن أطربنى - - ت وقل لى بعض أشعارك

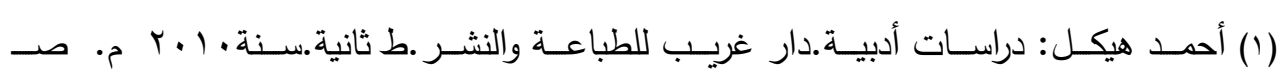
r. (r) مصـرى عبـد الحميـد حنـورة: الأسـس النفسـية للإبــاع الفنى فـى الثـعر المسـرحى. صـ 


$$
\text { ولو يوماً ملكت الأرض أحب أشعارك }
$$

فهذا الملك قد يمضى

ويرحل مثلما رحل الملوك

ويبقى الشعر ... يا ملك الملوك (1)

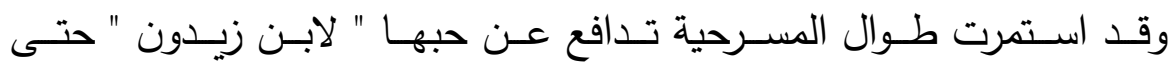

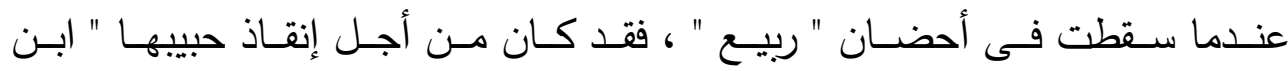

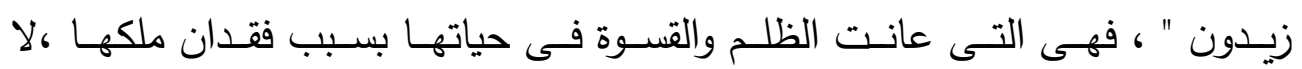

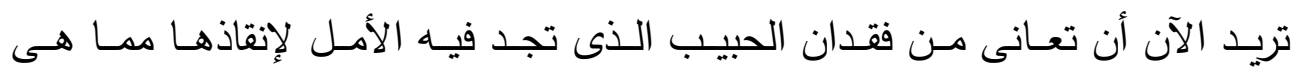
ولادة : أنا لم أخنك ... و الله يوماً لم أخنك ما كنت يوماً أستطيع لو كنت تعرف يا وليد بأننى خيرت يوماً أن أموت ... وأن تعيش ... فاخترت وحدى أن أموت ... لكى تعيش أنا لم أخنك ورإنما 
قد خنت نغسى يا وليد لكى تعيش ...

$$
\text { خيرت فى عمى وعمرك }
$$

فاخترت عمرك (1)

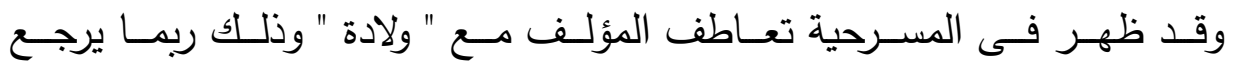

إلى أنسه جعل منهـا رمـزاً للـوطن ، حتى إنسه عندما جعلهـا تسقط فىى المسـرحية ، فقد كـان هـا السـوط يمثل سـقوطاً للأنـدلس ، ولـيس سـقوطاً لامـرأة أشـيع حولهـا

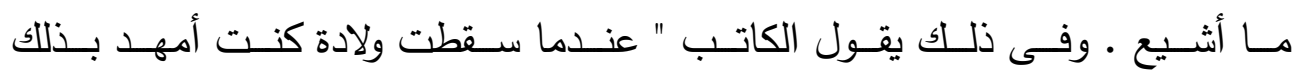
لسقوط الأندلس،أى أنها رمز سقوط وطن وليس مجرد سقوط امرأة"(؟) ومـن ثـم يمكـن القـول بـأن " فـاروق جويـدة " اســــاع أن يختــار عـدداً مـن الشخصـيات تجســ الواقـع التـاريخى الـذى أراد أن يعبـر عنـهـه ، واسـتطاعت

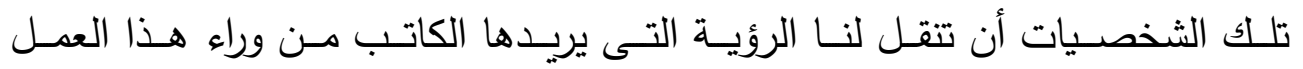

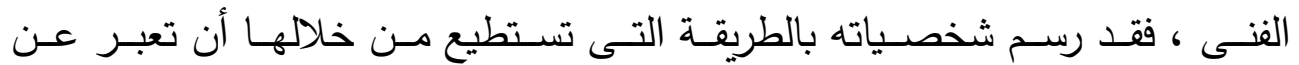

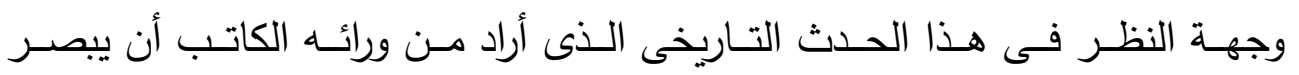
أبنـاء المجتمـع العربـى بــا سـيحدث لهـم إذا ظلــوا صـامدين تجــاه حكـام أمثــال

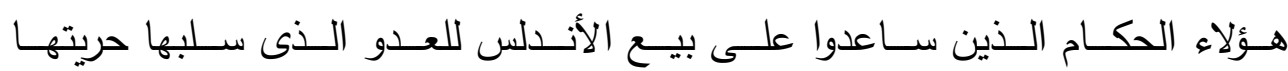
وعزتهـا لـذا نجده وفق فى " اختيـار شخصـياته الواقعيـة البسـيطة ، وأنطقهـا بمـا

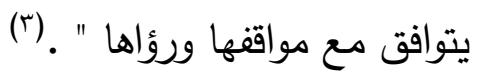

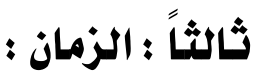

$$
\text { (1) الوزير العاشق : صـ مץ| }
$$

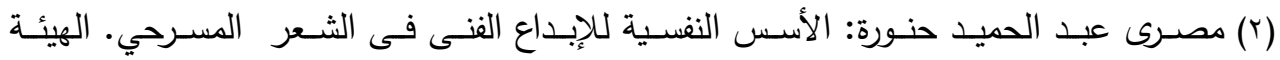
العامة للكتاب.سنة الح 9191

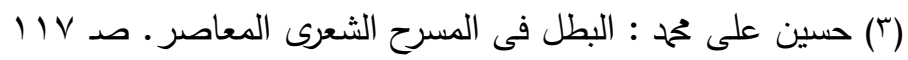




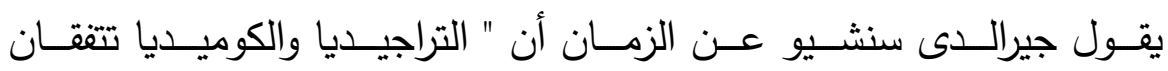

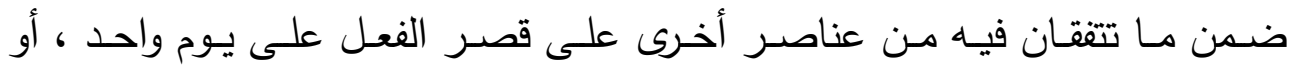

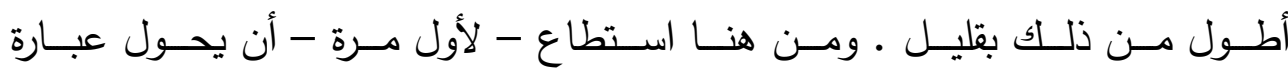

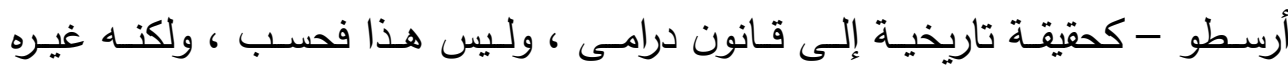

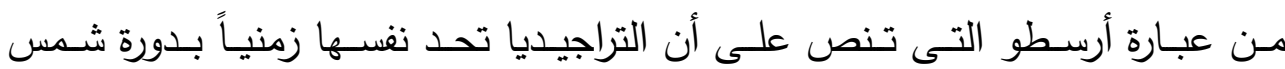

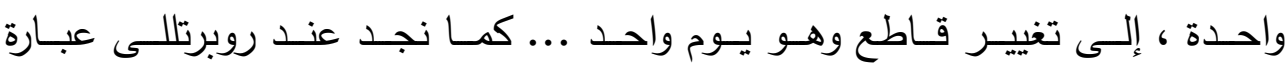

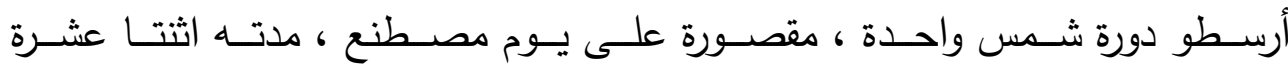

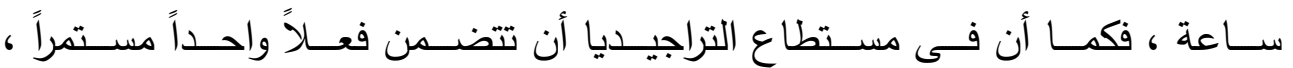

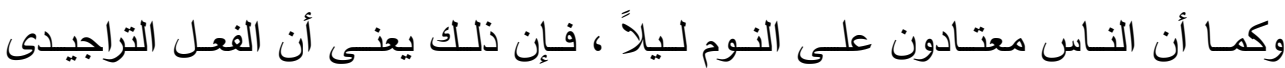

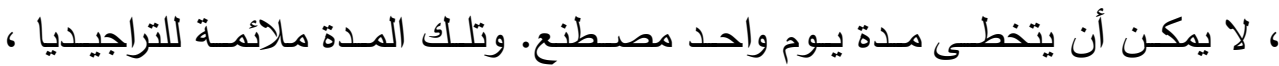

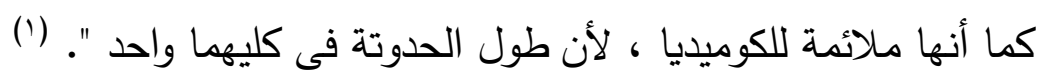

تسـتغرق المسـرحية فترة طويلـة مـن الـزمن تصـل إلى ســوات عديــة ،

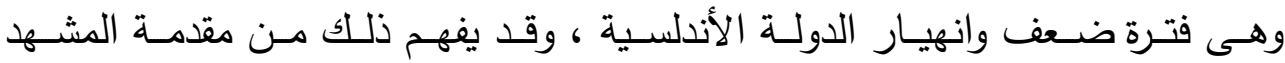
الأول فى القسم الأول من المسرحية . أبو حيان : من ألف عام أو يزيد .... كانت هنا يوماً حضارة ... - ك 
أمجاد شعب كان يعرف ما يريد

$$
\text { وعلى ربوع الأندلس - و }
$$

وقف المؤذن كى يجلجل بالآذان ...(')

وممـا يـدل أيضـاً على اسـتغراق المسـرحية فتـرة طويلـة مـن الـزمن ، مـا ورد فـى

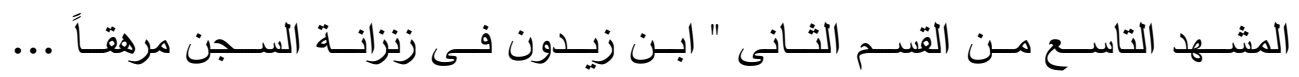

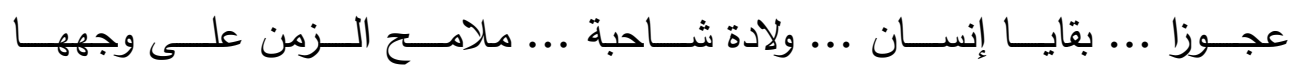

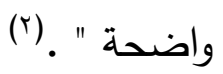

ولــا نقــول إن الكاتـب جعـل مـن فتـرة ضـعف الأنــلس وانهيارهــا زمنــاً مرجعيـاً لأحداث

\section{:مناصر الزماز :}

لــ يشـر " فـاروق جويـدة " إلـى عناصـر الزمـان التـى اعتمـد عليهـا إلا

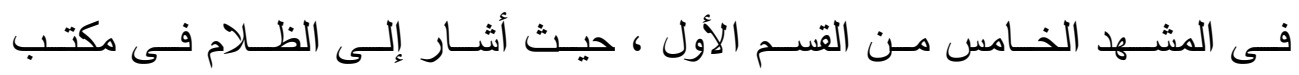
- الملك

" مكتب الملك ... فى جانب إضاءة .. والظلام فى مكتب الملك نفسه..".(؟)

$$
\begin{aligned}
& \text { (1) الوزير العاشق : صـ V } \\
& \text { (ז) الوزير العاشق : صدهبا } \\
& \text { (r) الوزير العاشق : صـ هـ }
\end{aligned}
$$




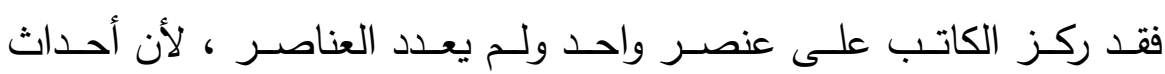

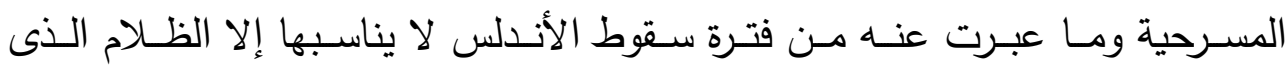

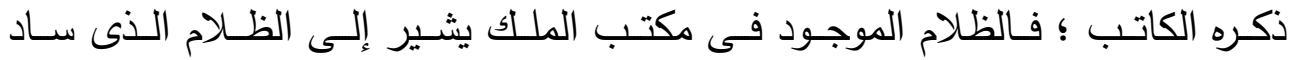

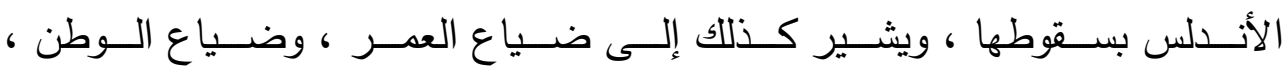

$$
\text { والحب الذى كان بين " ابن زيدون " و " ولادة " . }
$$

فأحـداث المسـرحية جميعها لـم يكـن بهـا مـا يشـير إلـى الأمـل ، وبالتـالي

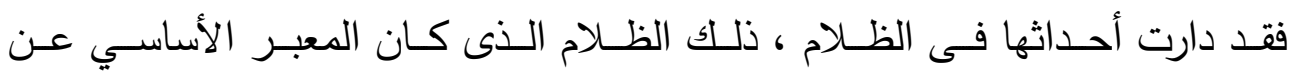

هذا السقوط والضياع لتلك الحضارة التى استمرت حوالي ألف عام أو يزيد.

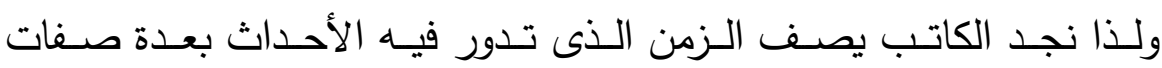

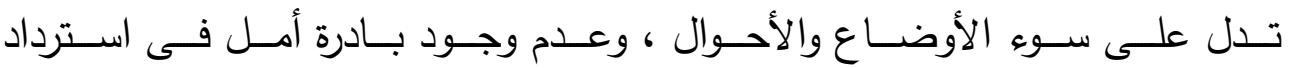

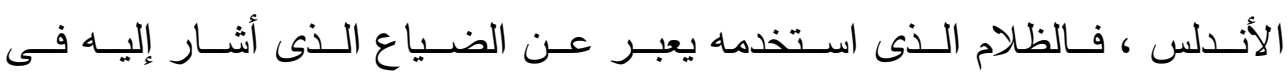

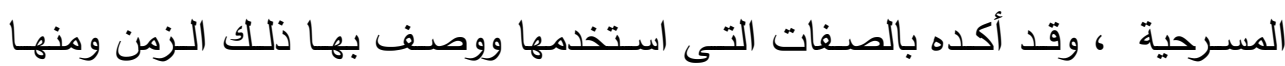

طهر فى زمن عربيد

فى زمن السفلة والسفهاء

زمن يصير الكفر إيماناً

يصير الزيف حقاً

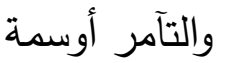




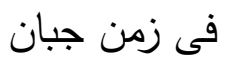

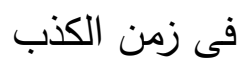

(1)

رابعاً : المكان :

" المكـان هـو الإطــار المحـد لخصوصـية اللحظــة الدراميـة المعالجــة ،

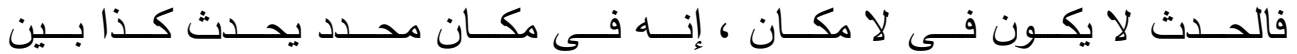

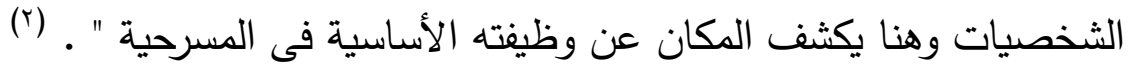

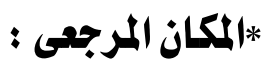

تـدور أحـداث المسـرحية فـى مدينــة " قرطبـة " والتي جعـل منهــا الكاتب مكانـاً

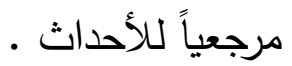

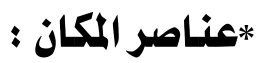

تعـدت عناصـر الككـان فـى المسـرحية ، حيـث دارت فـى " بيـت ابـن

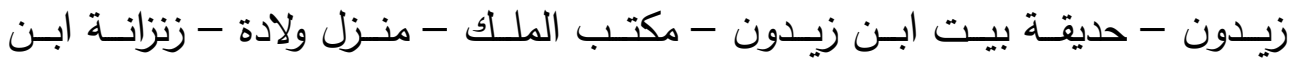

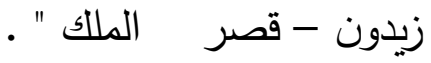

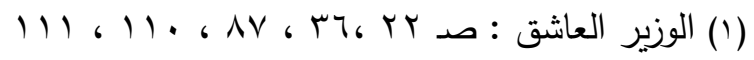

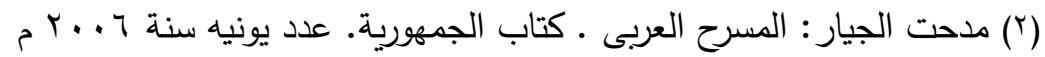

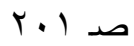




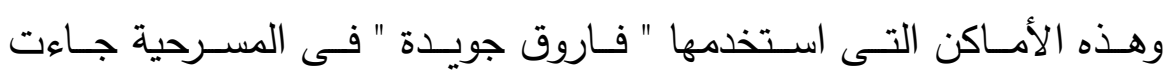

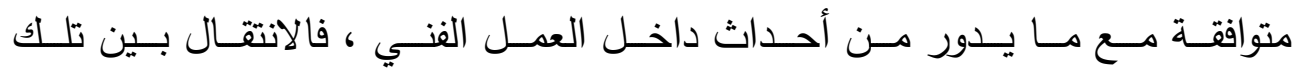

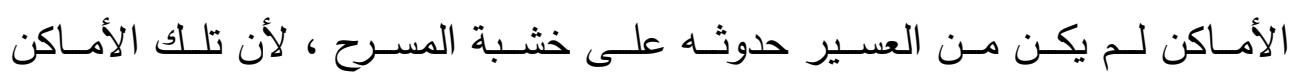

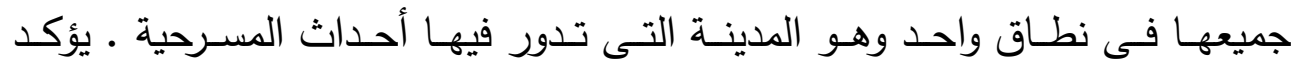

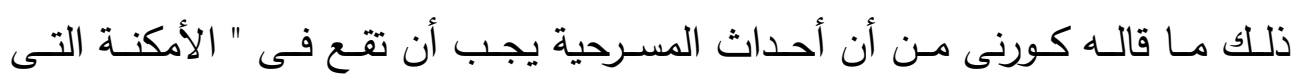

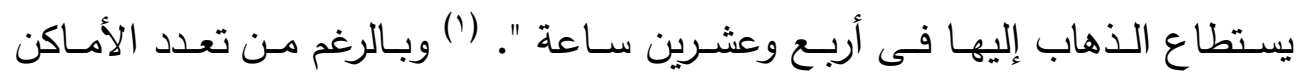

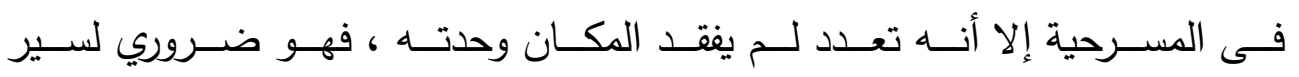

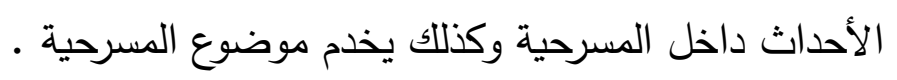

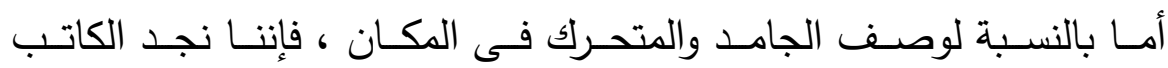

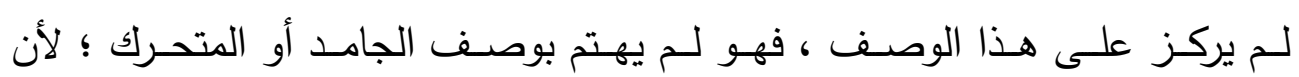

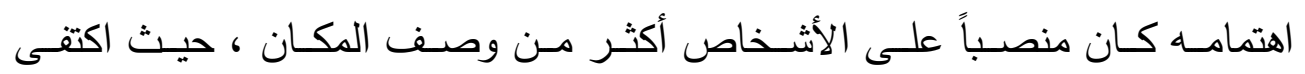

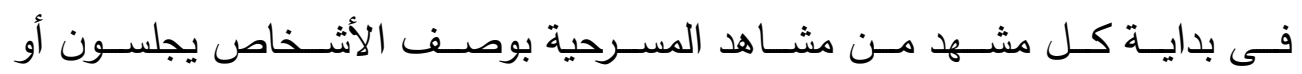

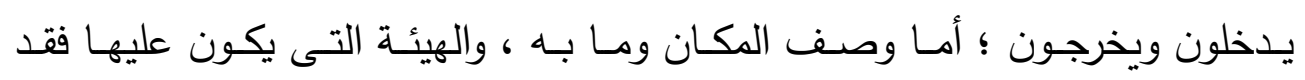

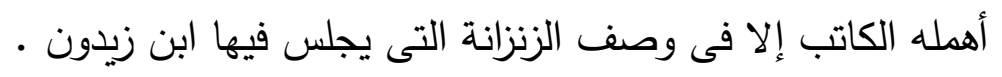
بـن زيـدون مرهفاً حزينـاً يقف فى زنزانـة رديئة قذرة وبجـوار بابها حسارس غليظ (r). "..

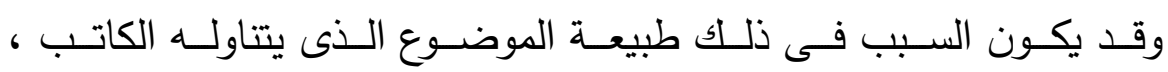

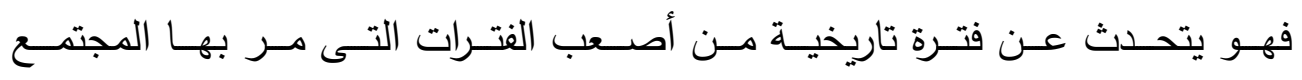

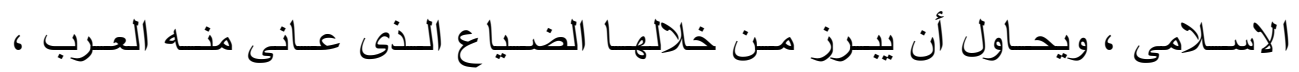

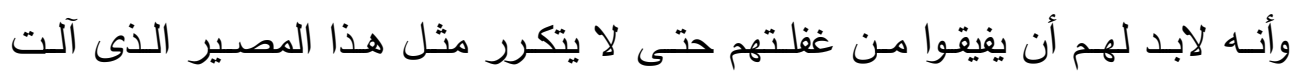

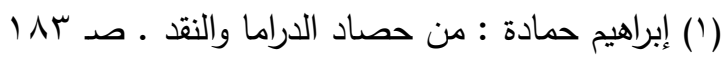

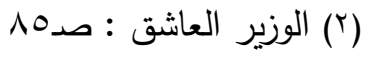




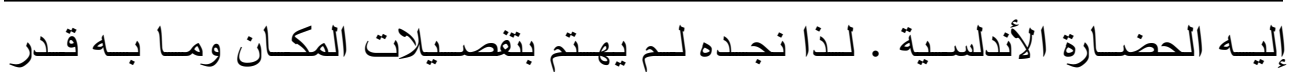
اهتمامه بالحدث الذى يدور داخل المكان •

\section{خامساً: : اللغة والحمار :}

إن اللغـة فـى المسـرح هـى " الوسـيلة الأوليـة والأساسـية للتعبيـر الـدرامي

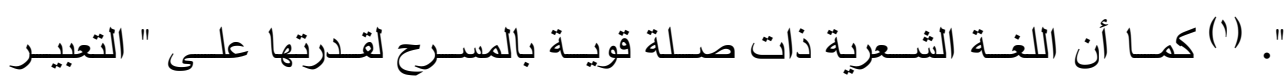

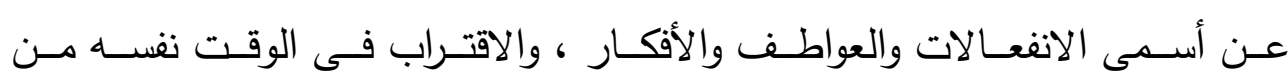

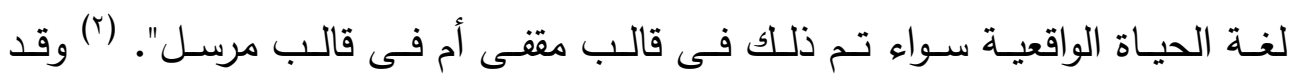

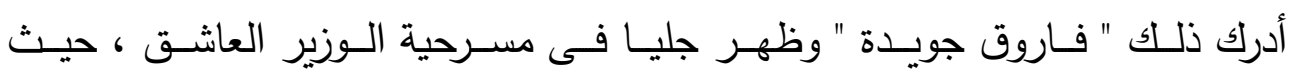

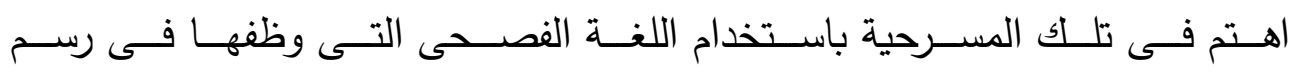
شخصـياته ، وتصــوير المواقـف التـى تـدور فـى المسـرحية ، وكـذللك تطـــير الحـثث ، وتعميـق الصـراع بـين الشخصـيات ، والـذى هـو أسـاس العمـل الـدرامي

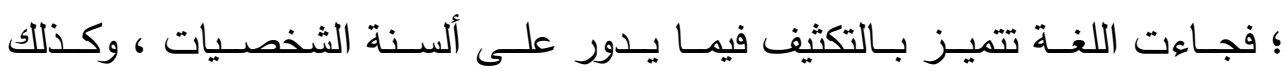
اســتخدام المفـردات ، والجمـل الحواريـة التـى تعبـر عـن المواقـف التـى تريـــــا

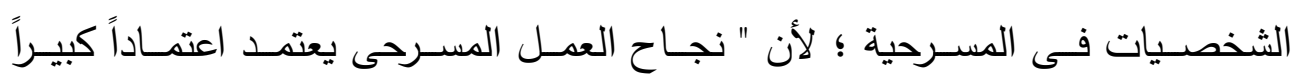

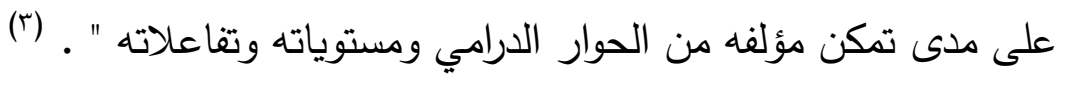

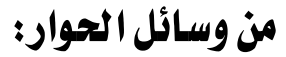

من الوسائل الحوارية التى استخدمها الكاتب فى مسرحيته:

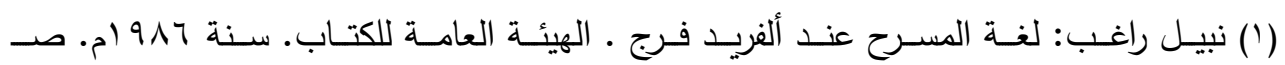

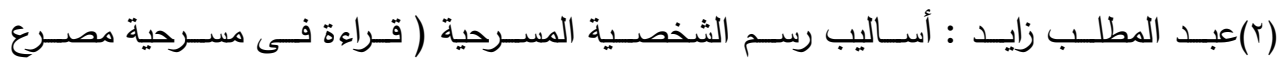

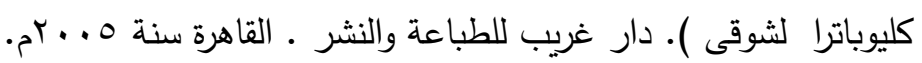

صد 14

(ץ) نبيل راغب : لغة المسرح عند ألفريد فرج • صـ بهر 


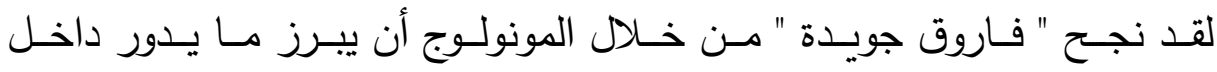
الشخصـيات مـن صـراع وحيـرة بـين التضـحية بـالنفس أو مـوت الحبيـب ، ومـن أمثلــة ذلـك المونولـوج الـذى ورد على لســان " ولادة " حينمـا ذهـــ إليهـا ربيـع " يخيرها بين الزواج منه أو قتل الوليد فى السجن • ولادة : تدور على المسرح

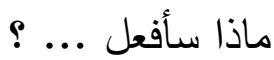

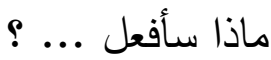
إن قلت : لا ع... مات الوليد .... إن بعت نفسى سوف أقتل كل يوم أ أبيع نفسى ... أم أبيع أبا الوليد ؟ هو حب عمرى ... كل حلمى فى الحياة ....

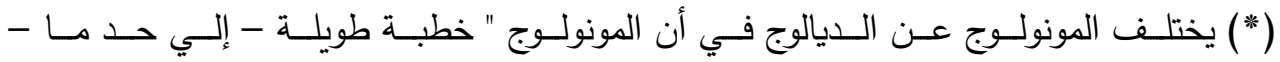

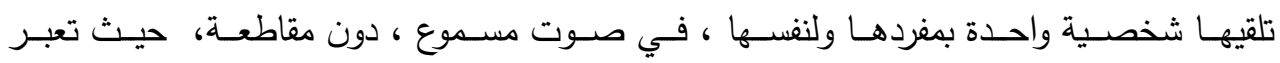

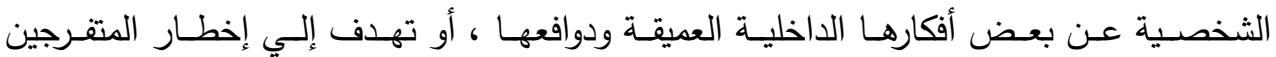
بمعلومات معينة ترتبط بما يجري في المسرحية من وقائع ".

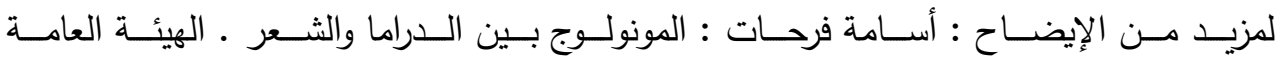

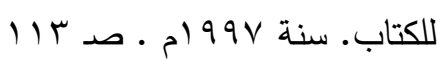

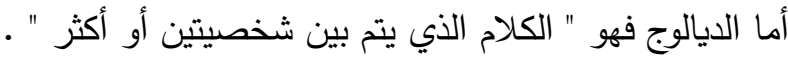

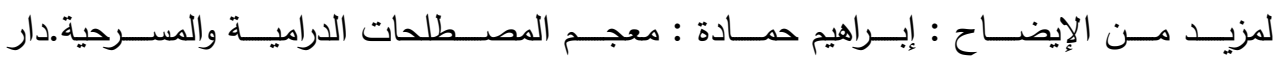

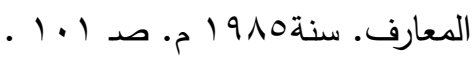




$$
\text { وعرضى .. هل أفرط فيه من أجل الوليد .. ؟ }
$$

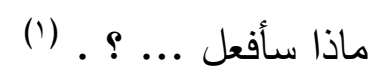

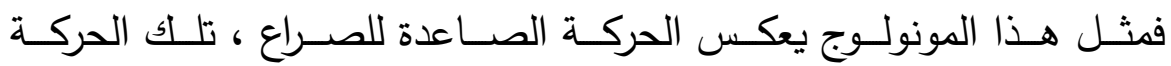

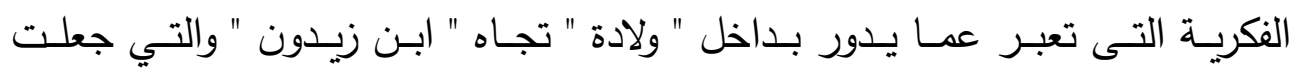

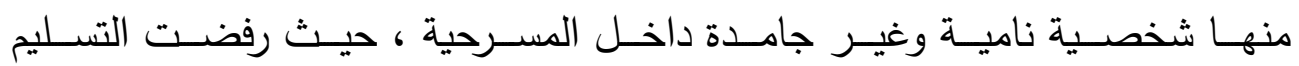

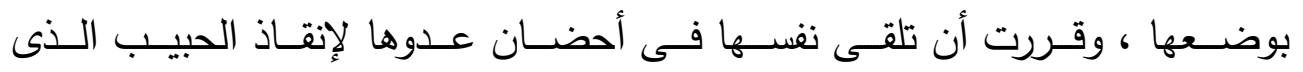

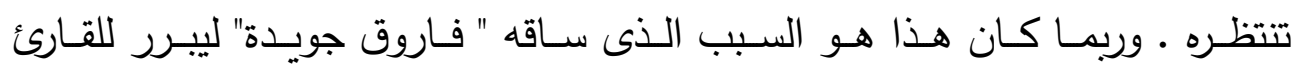

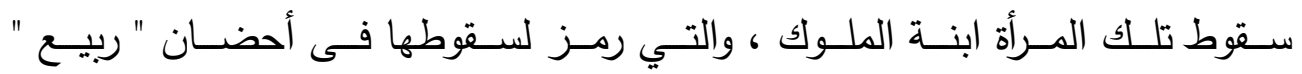
بسقوط الأندلس فى أيدي الفرنجة .

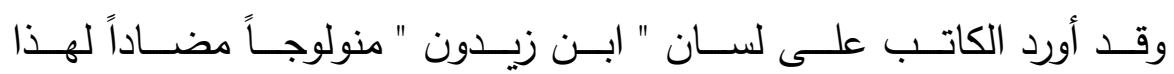

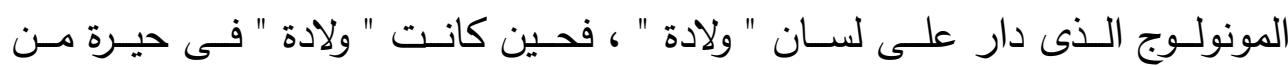

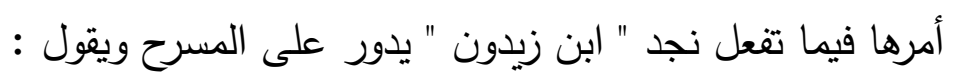
ابن زيدون : إذاً خانت وماذا بعد يا قلبى وقد خانتك ... وباعت حلمنا غدراً كما باعتلك ....

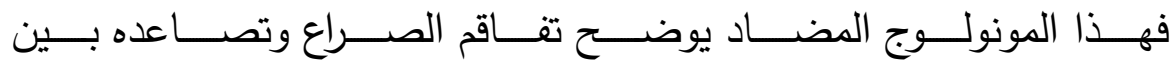

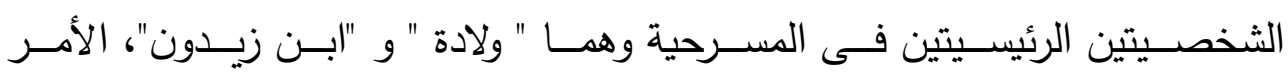

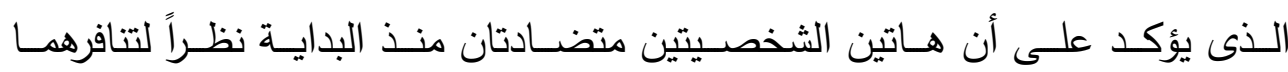

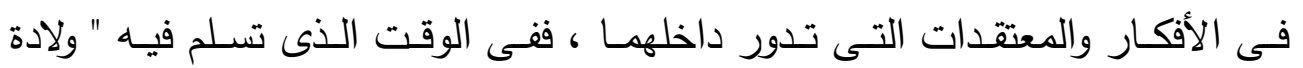




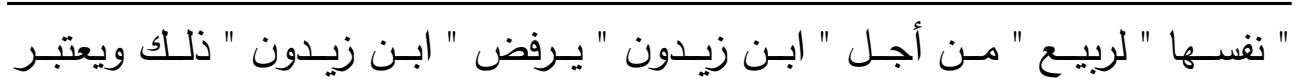
أن ذلك خيانة من جانبها للعهد الذى كان بينهما .

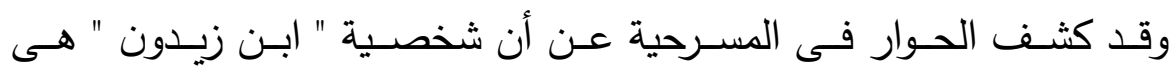

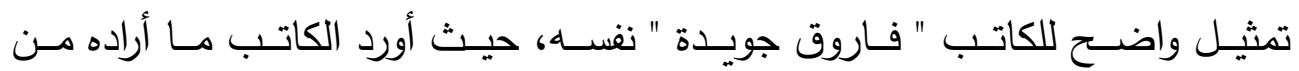

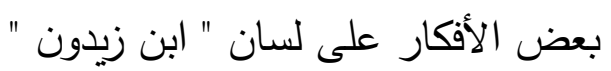
ابن زيدون : " يودع ضيوفه .. ويضع يده على كتف أبى حيان.. ويقول " حيان .. أعرف مأساة الثعوب ... حكامنا اعتادوا على هذا المديح ..

وشعوبنا اعتادت على هذا النفاق ...(') ويقول أيضاً : الواقع العربي يا مولاي ينبئنا بأن كوارث الدنيا ستلحق بالعرب ... - ك

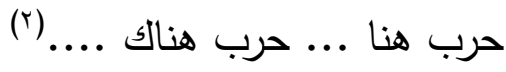
فهـا التعليـق بـالرأى الـذى قـام بـه " فـاروق جويــة " علـى لســان " ابـنـ

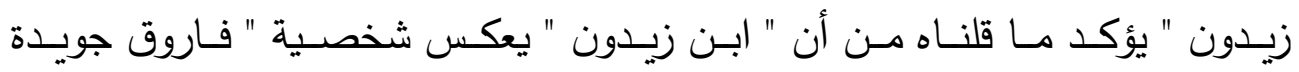

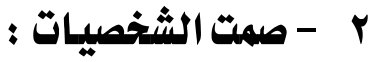

$$
\text { (1) الوزير العاشق : صدء) العاشق : صداب }
$$




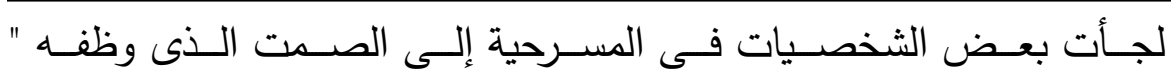

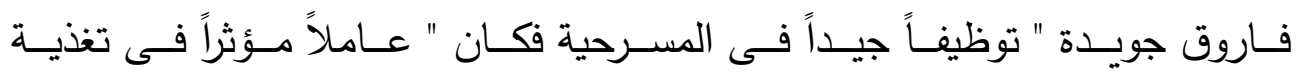

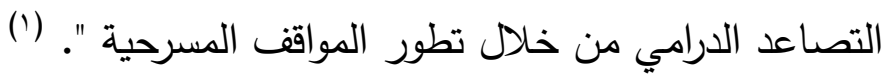
وقد ظهر ذلـك جليـا بعد الحسوار الذى دار بـين "ولادة " و " ربيـع " الذى أعقبـه

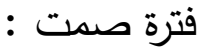
ولادة : ماذا تريد الآن منى يا ربيع أنسيت أنك خائن للعهز إنسان وضيع ....

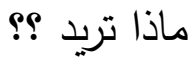

$$
\begin{aligned}
& \text { ربيع : " ببرود شديد " } \\
& \text { لا تتسى إكرام الضيوف ... } \\
& \text { وأنا ببيتكا يا مليكة ملكنا .... } \\
& \text { ولادة : ماذا تريد الآن خبرني ... وإلا ...... } \\
& \text { ربيع : ماذا تفعلين ............ } \\
& \text { ولادة : حراس بيتي يطردونك . } \\
& \text { ربيع : بوقاحة } \\
& \text { حراس بيتك ... }
\end{aligned}
$$

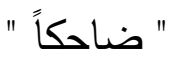

(') سامي منير حسين عامر: من أسرار الإبداع النقدي في الثعر والمسرح. منشأة

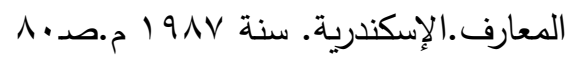




$$
\begin{aligned}
& \text { حراس بيتك من رجالي إن أردت الآن } \\
& \text { ألقي بالمليكة خارج الأسوار عارية } \\
& \text { يراها الناس في كل المدينة } \\
& \text { ومضيت في كل الشوارع أشهر الأحياء } \\
& \text { أن رجالنا وجدوا الأميرة في الفراش } \\
& \text { وليس يعني من يكون علي فراشك } \\
& \text { حارس أو سائق ... أو بائع .. } \\
& \text { " فترة صمت " }
\end{aligned}
$$

$$
\text { ولادة : نذل حقير .... (1) }
$$

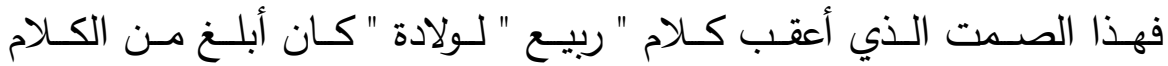

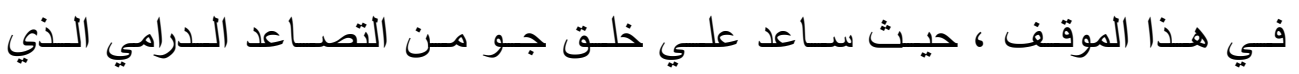
وصل بالحدث إلي ذروة لا يستطيع الكلام أن يقوم بها.

ومـن ثم يمكـن القـول بـأن " فــاروق جويـدة " أسـتطاع أن يـأتي بـالحوار

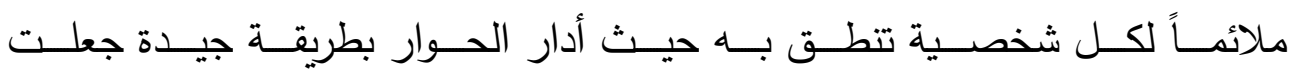

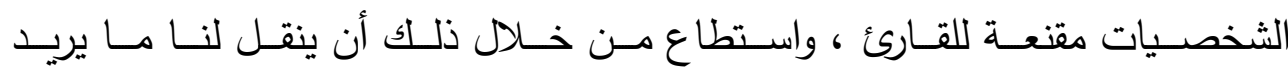

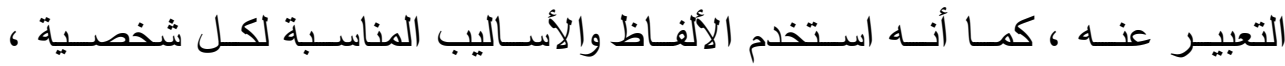

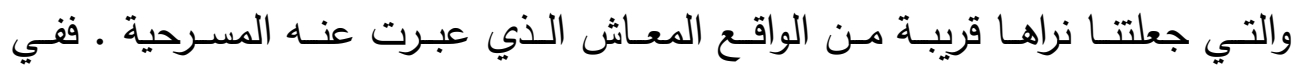

$$
\text { (1) (الوزير العاشق : صـ 99 ، ... (1) }
$$


تلـك المسـرحية نجـد فـاروق جويـدة " يبـدأ مـن التـاريخ لينطلـق منـه إلـي رؤاه عـن

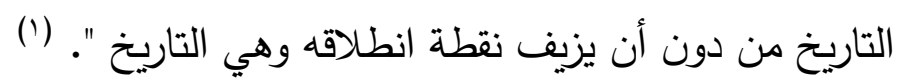
لقـــــــــاع أن يــوائُ بـين القصــة التاريخيـة والموقـف المعاصـر ، وأن "

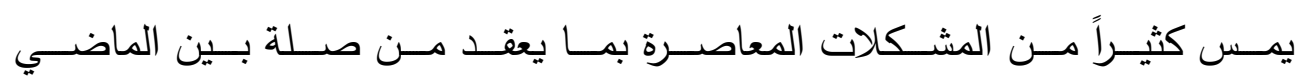
والحاضـر وبمـا يختـار مـن موضـوعات تاريخيـة تشـبه في جوهرهـا موضـوعات

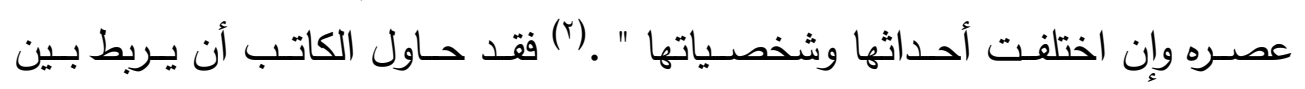
التـاريخ والحاضـر ، فعبـر عـن بعضض القضــايا فـي المجتمـع الـــي نعيشـهـ مـن

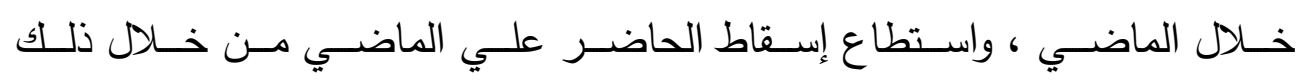

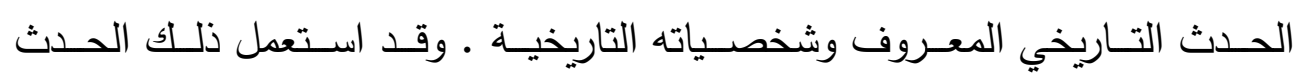
التـاريخي لأن فيـه دلالـة واضـحة علـي واقعنـا العربـي الـذي نعيش فيـه فاسـطـاع

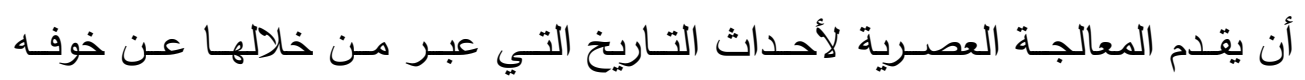

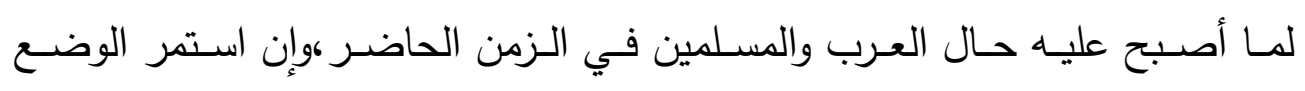
علي مـا هـو عليـهـ مـن ظلـم وعنف وضـعف وتفكلك فسـوف نصـير إلـي نفس

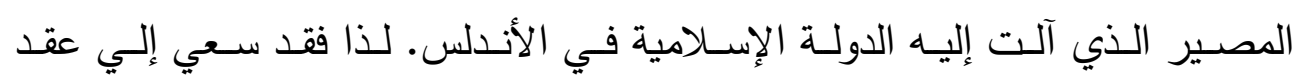

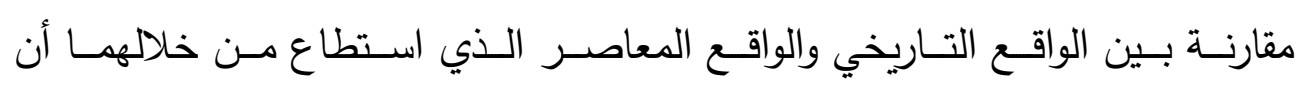
"يطرح الحلم الفردي لابن زيدون في القالب التراجيدي الكلاسيكي المعهود".(r)

(1) أحمد سخسوخ : الدراما الشعرية بين النص والعرض المسرحي.الهيئة المصرية العامة للكتاب.

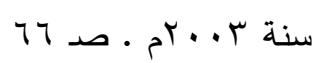
(r) عبـد القــادر القـط : فـي الأدب المصـري المعاصـر ( دراسـة تطبيقيـة لمشككلات معاصـرة

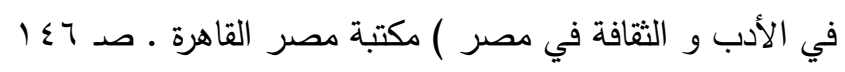

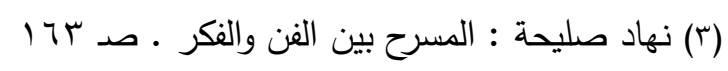




\section{النموذج الثانى : دماء علي أستار الكعبة : فاروق جويلدة: رئرة}

\section{أولاً : المضموز :}

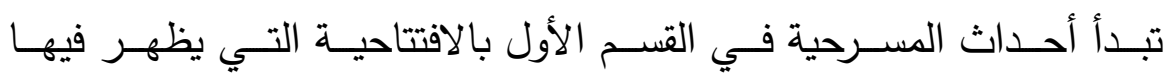

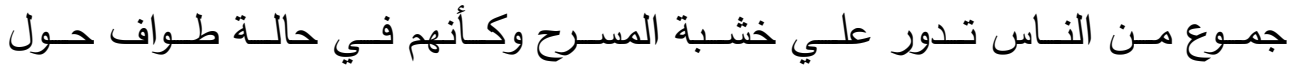

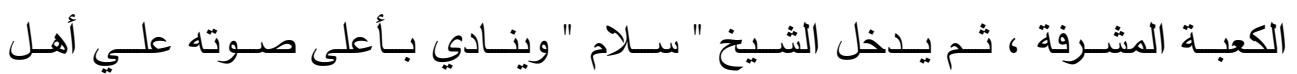

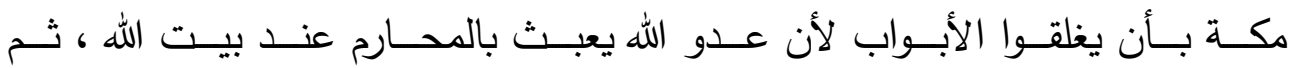

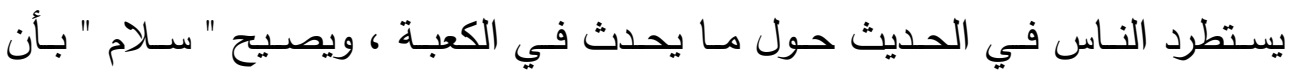

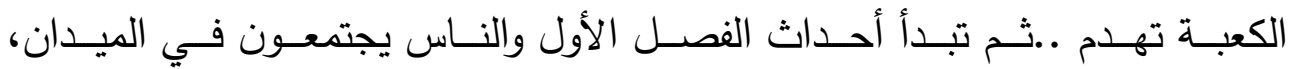

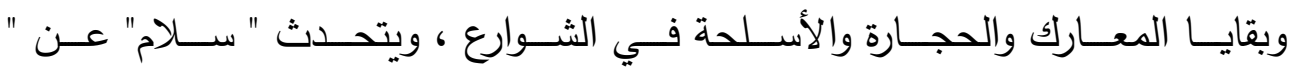

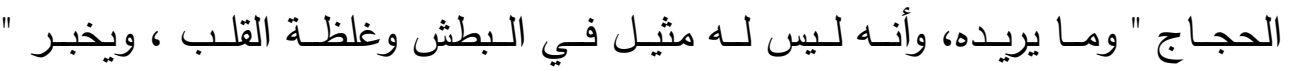

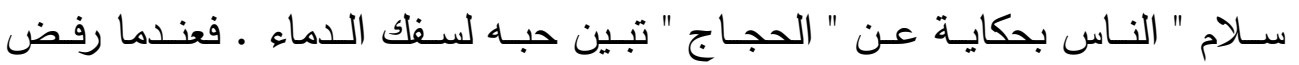

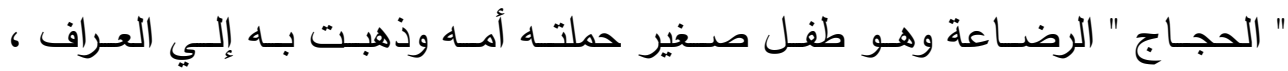

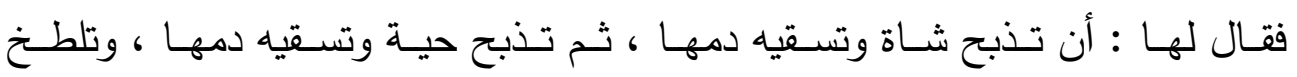

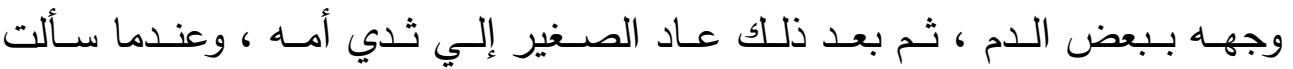

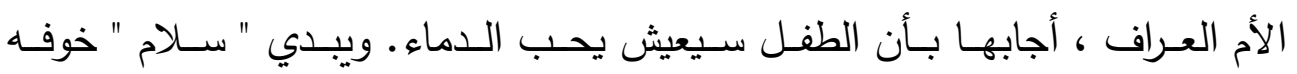

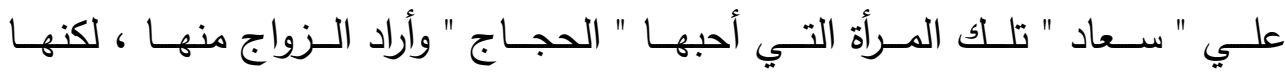

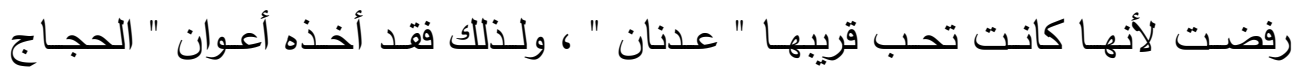

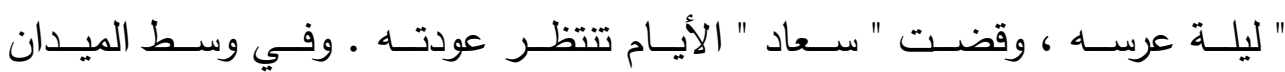

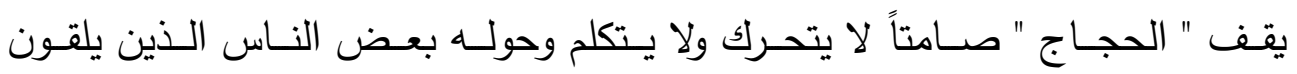

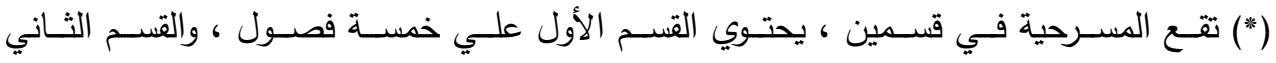

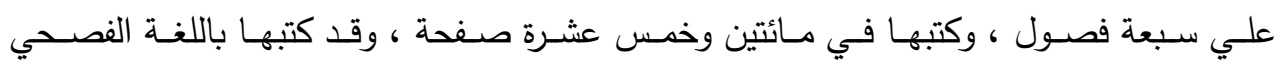

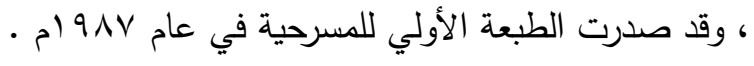


عليـهـ بعبـارات المـدح والثتــاء ، ويسـتمر الحجــاج فـي صــــه ـ ويعلـن الجميـع

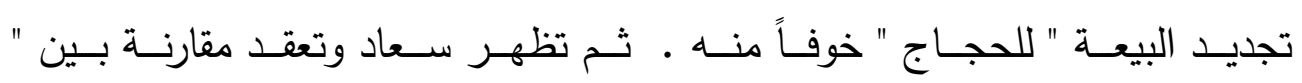
عـدنان " والحجــاج ، ثـم تـدور علـي المسـرح فـي شـبه جنـون ، وتسـتمر فـي

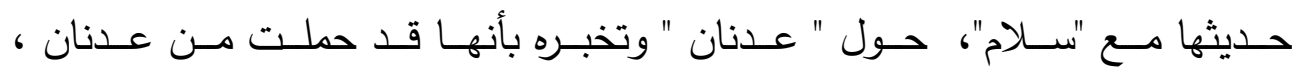
ويتعجب سـلام مـن قولهـا لأنـه قد مضـي عشـرون عامـاً علي فراق عدنان ، وهـا

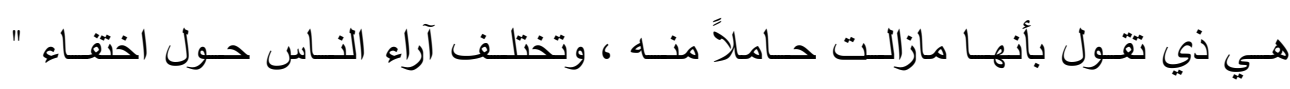
عـنان " ، وتسـتمر " سـعاد " في حـديثها عـن ذلـك الطفـل الكـائن في أحشـائها

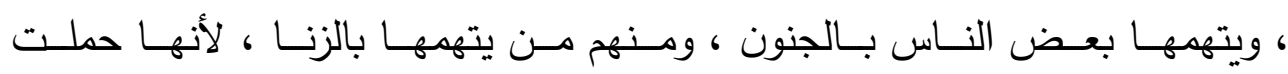
سفاحاً

و ننتقـل إلـي الفصـل الرابـع حيــث يجلـس " الحجــاج " فـي مكتبـهـ مــع ممثلي الشـب يتتـافش معهم حـول طريقـة الحكم ، ويختلف الجميع في آرائهم،

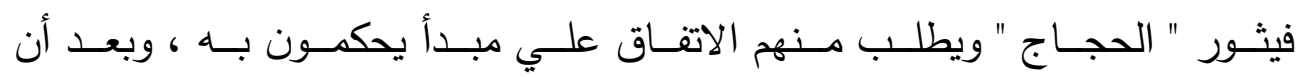

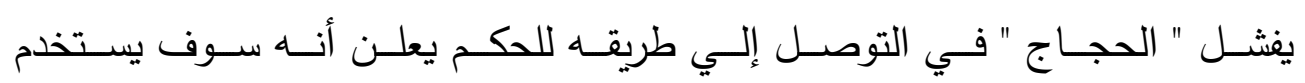

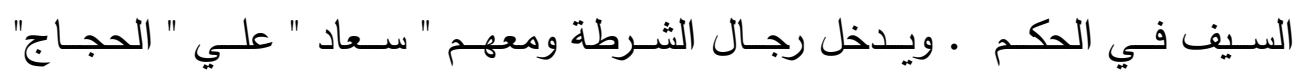

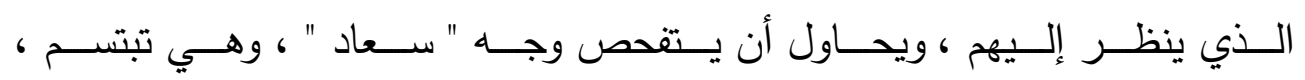

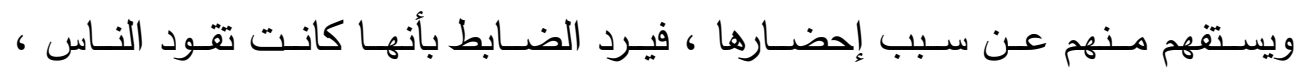
وتـدعوهم للثـورة فـي الميـدان الكبيـر ، ويطلـب مــنهم أن يتركوهــا معـه، ويخـرج الجميـع وتبقـي " سـعاد "و " الحجـاج" الـذي يقتـرب منهـا ويرحـب بهـا ، ويتحـدث معهـا عـن جرحـه الذي مـازال كائنـاً في أعماقـه ، وأنـه مـازال يـذكرها عندما كانـا صـغيرين ؛ وهنـا تتخيـل " سـعاد" كأنهـا تقفـ أمسام " عـدنان " وتحدثـه بمـا يـدور

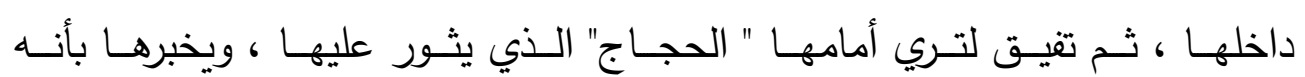

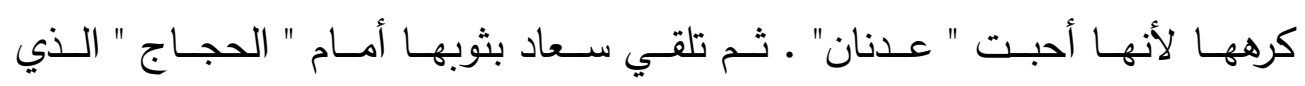

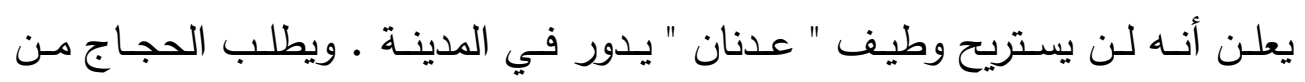




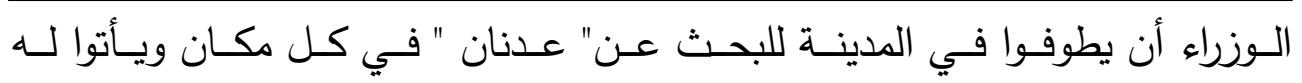

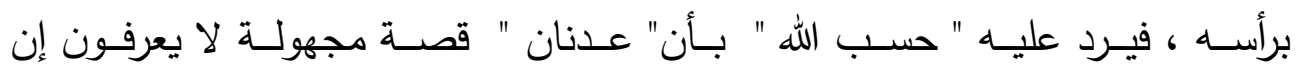

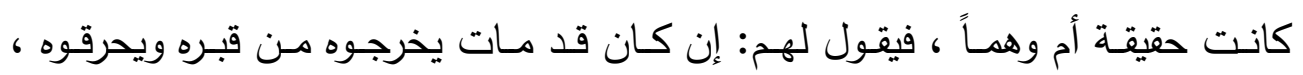

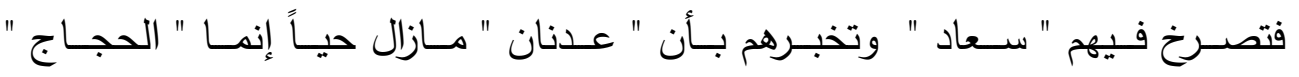

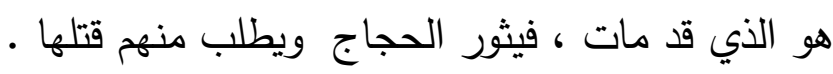

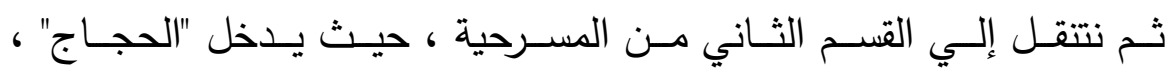

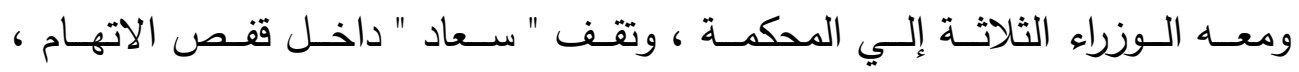

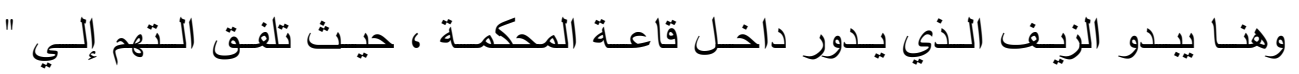

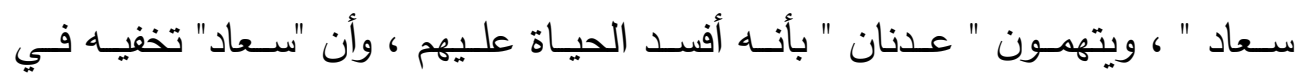

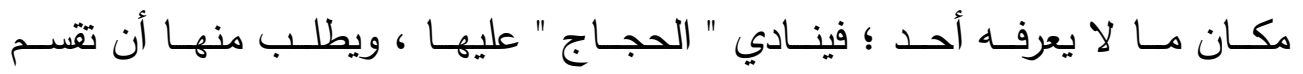

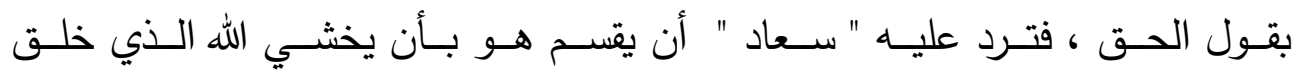

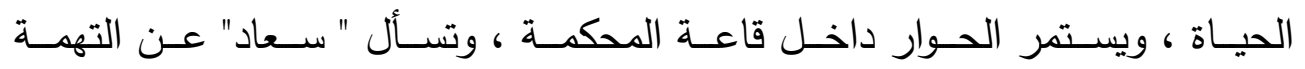

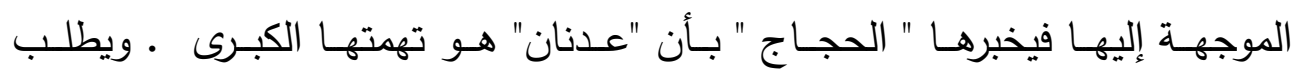

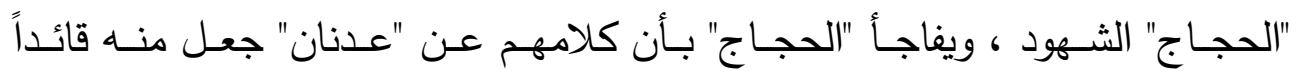

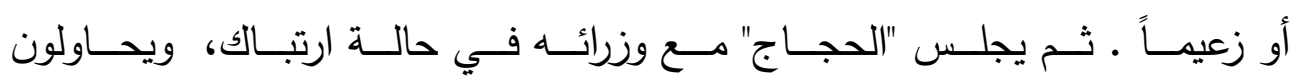

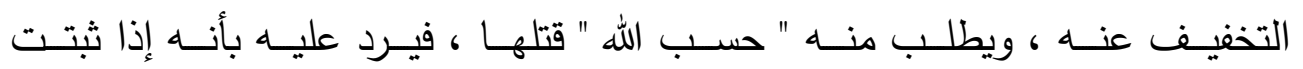
جريمتها سيقتلها .

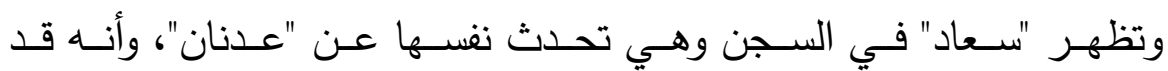

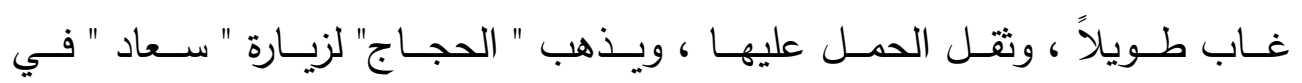

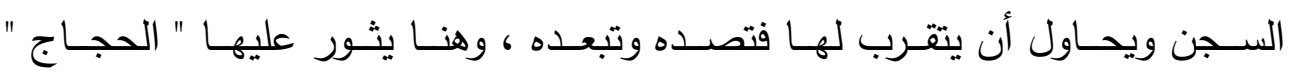

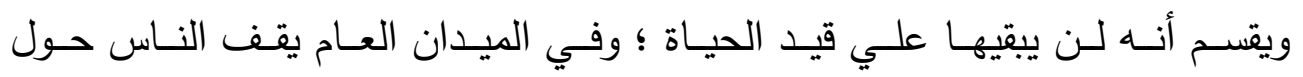

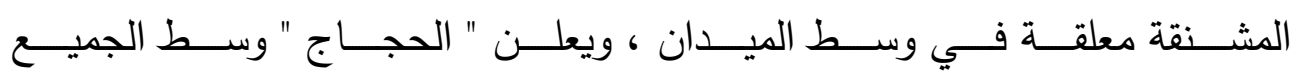

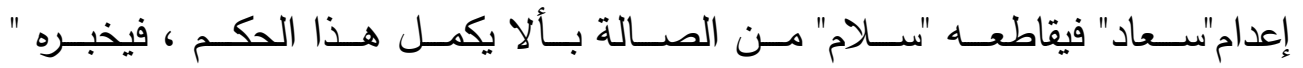




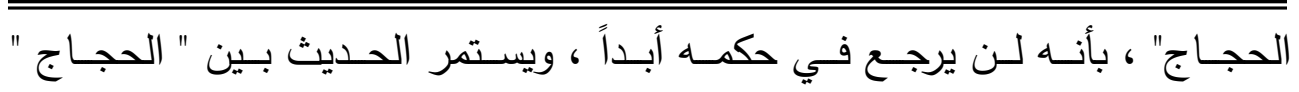

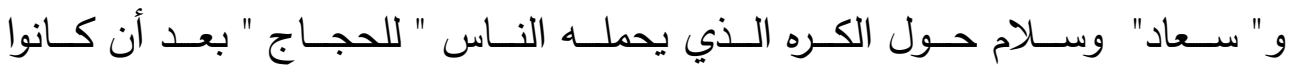

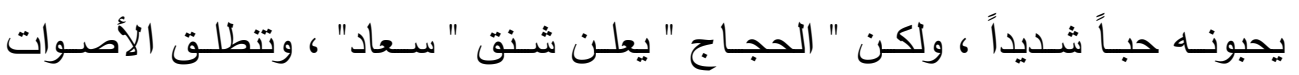

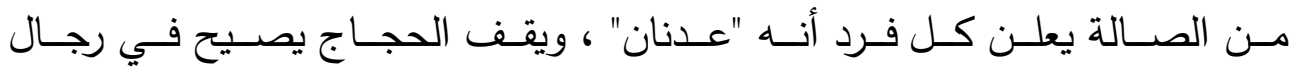

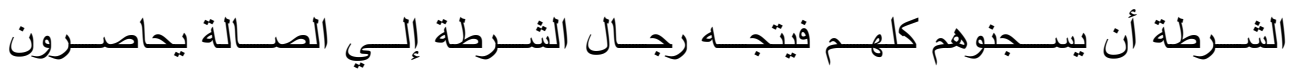

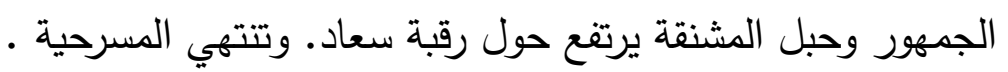

\section{* تعليـــق :}

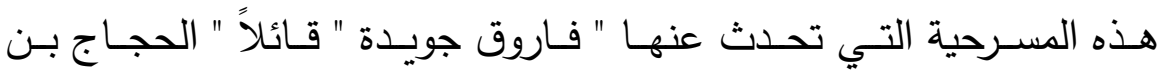

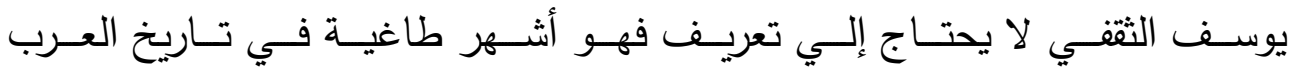

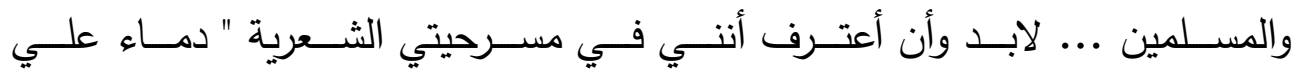

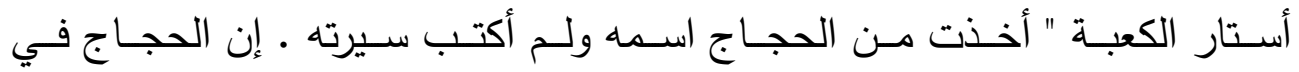

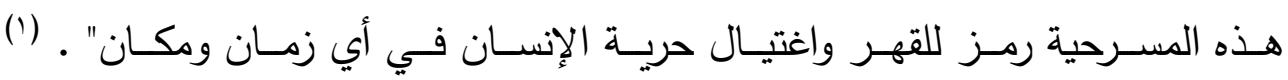

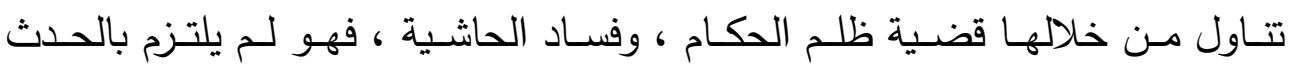

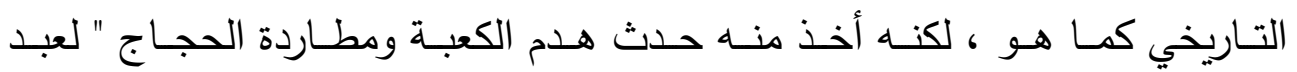

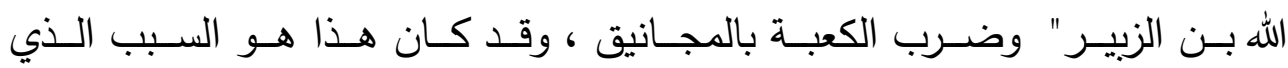
استقي منه" فاروق جويدة "اسم المسرحية "دماء علي أستار الكعبة " .

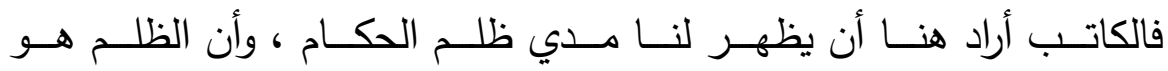

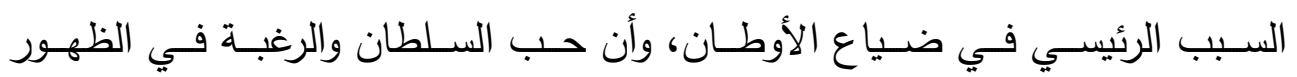

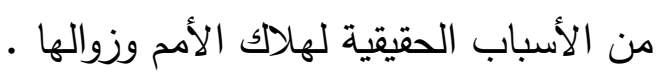
فـالمؤلف كمـا سـبق أن أشـرنا في مسـرحية " الـوزير العاشـق " يلجـأ إلـي

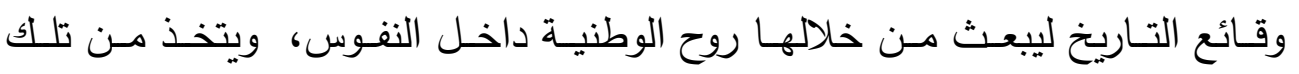
(') فاروق جويدة : دماء علي أستار الكعبة ـ طدار غريب ـ د ت ـ الغلاف الأخير 


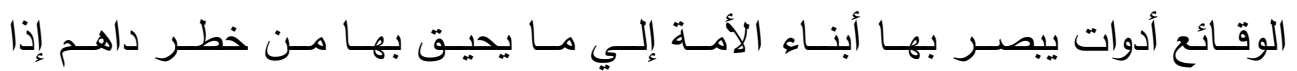

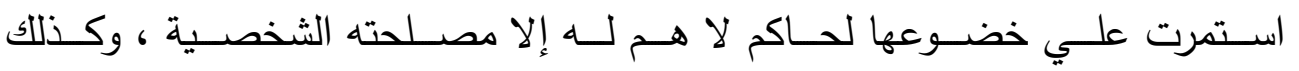

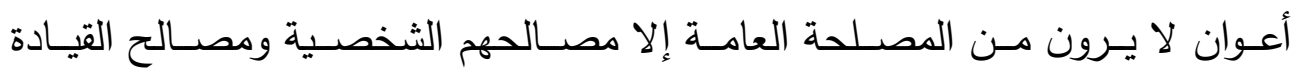

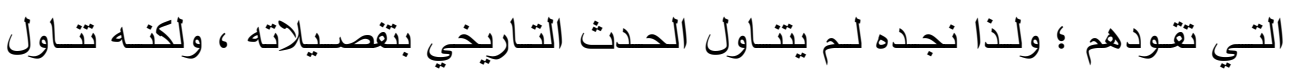

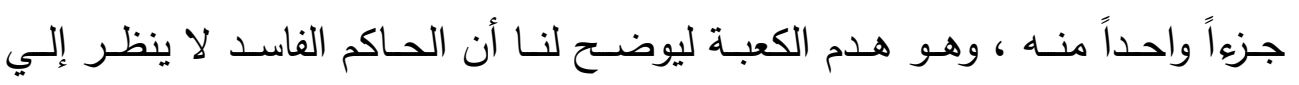

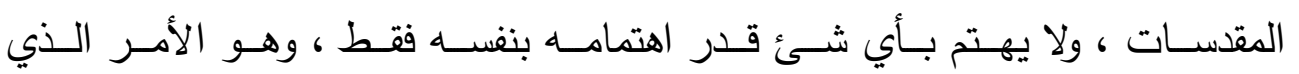

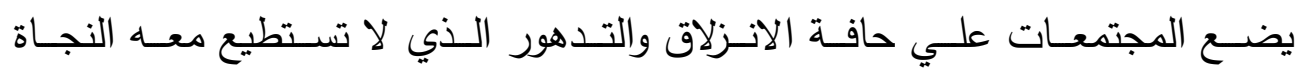

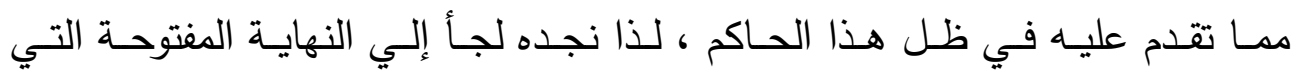

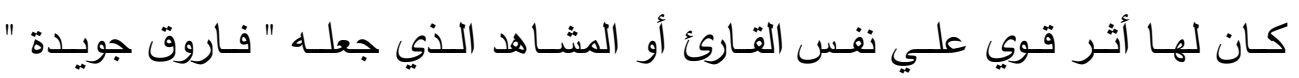

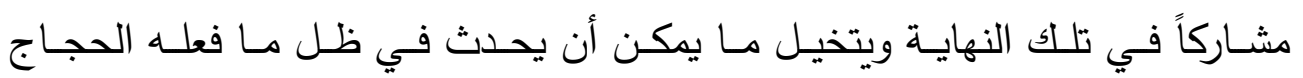

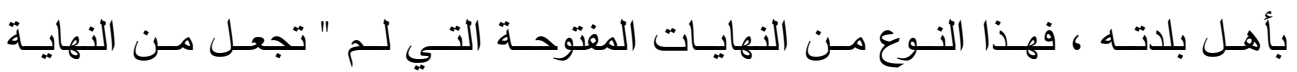

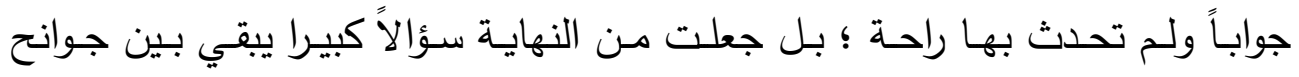

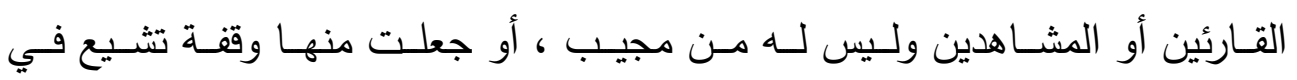

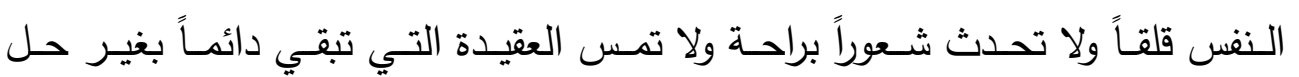

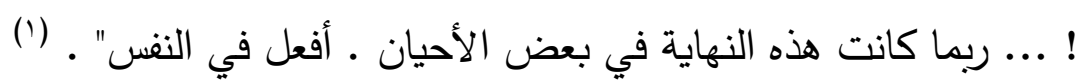
فالكاتـب فـي هـذه المسـرحية يحساول أن يجعلنـا نسـتخلص مـن التـاريخ

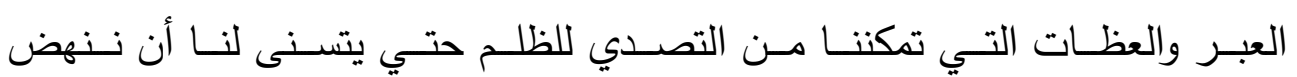
بهذا المجتمع ونرقي به وسط المجتمعات الأخرى .

\section{ثانياً : الشخصيات :}

" تعتبــر الشخصـية الدراميــة حسـب نظريــة الــدراما الحديثـة المحــرك

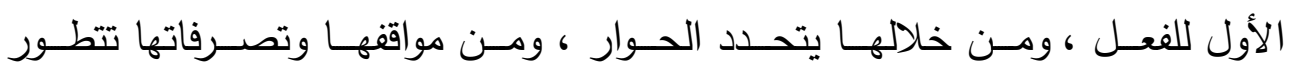

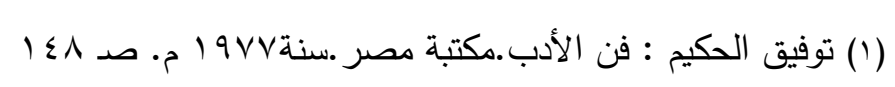


الــدراما" ـ (') وإذا نظرنـا إلـي الشخصــيات فـي مسـرحية "دمــاء علـي أســتار الكعبـة" نجـدها في معظمهـا شخصـيات بسـيطة نجـح الكاتـب في اختيارهـا مـن

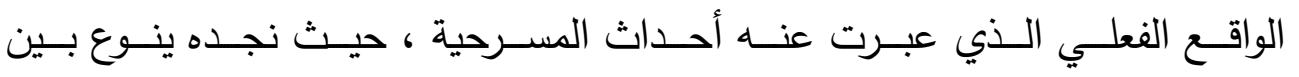
الشخصـيات الرئيسـيه التي يـدور حولهـا الحـدث ، والشخصـيات الثانويـة التي " تسـاعد علي إظهار شخصـية البطل وتسـاعد الجمهـور علـي معرفـة الكثيـر مـن

تفيلات الصراع" . (؟)

\section{وفيما يلي عرض لنماذج من تلك الشخصيات :}

$$
\text { : }
$$

هـو " الحجــاج بـن يوسـف الثقفي " أقوي حكـام الدولــة الأمويـة ، ويعـد " الحجـاج " الشخصـية الرئيسـية فـي المسـرحية ، فهـو رمـز للقهـر فـي كـل زمـان ومكــان وقــد قـال عنــهـ " فـاروق جويــدة " : أنــهـ " رمــز للقهـر واغتيــال حريــة الإنسان في أي زمان ومكان ". ومان

فهـو الثـخص المكـروه مـن جميـع مسن حولـه حتـي مــن أحسب ، حيـث نجـــ " سعاد " تتحدث عنه قائلة سعاد : لا تسألوني عنه .... إني أكرهه في أي أرض أكرهه ... في أي عصر أكرهه (£)

rober TL . Hilliard, writing for television and Radio, $4^{\text {th }}$ ed, California, (1) wads worth publishing company, 1984.p.305

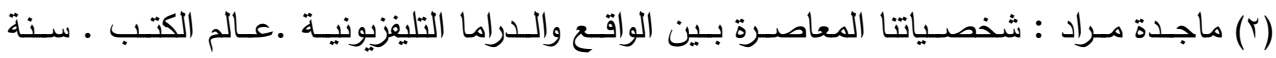

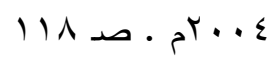
(ץ) دماء علي أستار الكعبة : الغلاف الأخير (ء) فاروق جويدة: دماء علي أستار الكعبة.الأعمال الثعرية .المجلد الثاني. دار الثروق. 


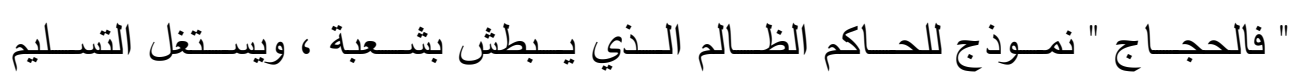

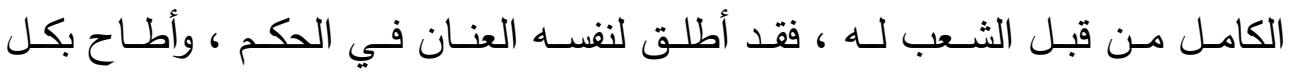

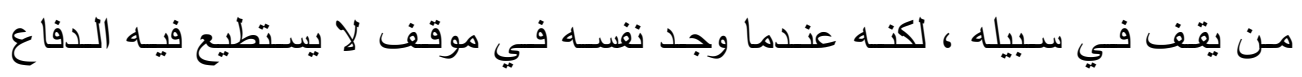

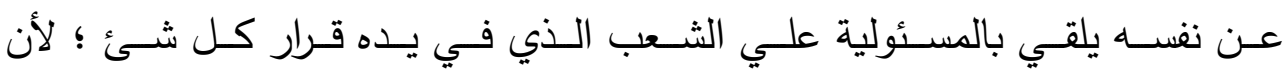

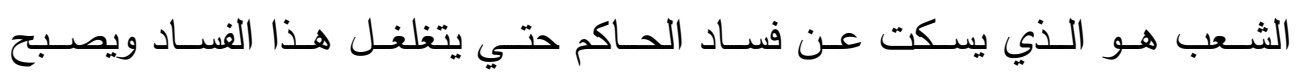

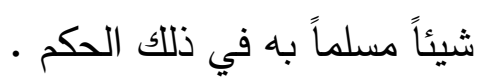

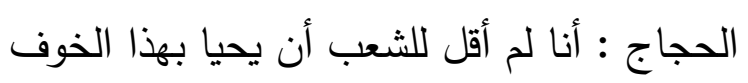

$$
\begin{aligned}
& \text { شعب يحب الخوف . } \\
& \text { يعيش لكي يخاف . } \\
& \text { ينام لكي يخاف . } \\
& \text { يموت لكي يخاف . } \\
& \text { يخاف لكي يخاف . } \\
& \text { سعاد : الخوف فيك وليس في شعبك . } \\
& \text { فالشعب لا يخشي السجون . } \\
& \text { لكن شعبك قد حزن . } \\
& \text { خيبت ظنه . } \\
& \text { ضيعت حلمه . } \\
& \text { إن باعني يوماً عدوي ... لا ألومه . } \\
& \text { إن باعني ابني فلن يبقي من الدنيا }
\end{aligned}
$$

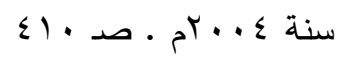




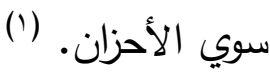

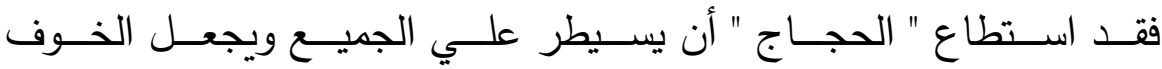

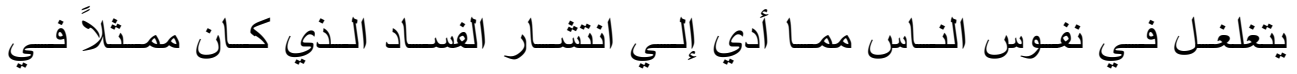

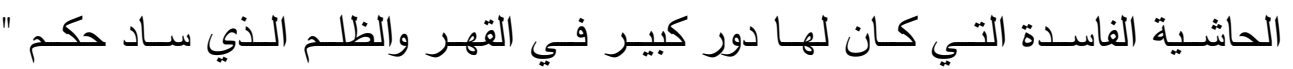
الحجــاج " ، فهـم يعرفـون كيـف ينـافقون "الحجــاج "، وكيـف يطوعـون الجـرائم

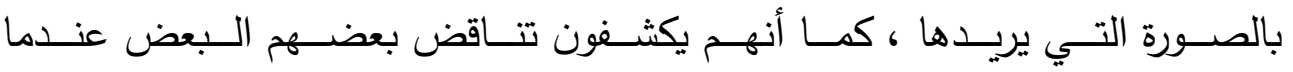

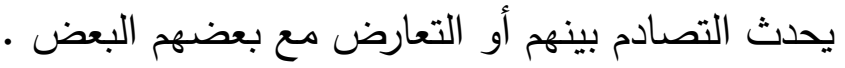
الوزراء الثلاثة : مولاى أمرك أفعل بنا كل الذي تبغيه

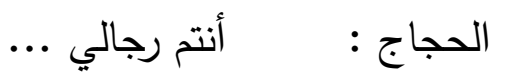

الوزراء الثلاثة : نعم رجالك دائماً ... الحجاج : في كل شئ تسمعون أوامري الوزراء الثلاثة : مولاي تأمرنا نطيع • (؟) ونجد هؤلاء الوزراء ينجحون في إيهام الحجاج بما ليس فيه من صفات رفيق الأنس : مولاي أنت العدل ... أنت الزهد .. أنت الأمن فينا ... والأمان .

هي دولة الإيمان يا مولاي حقاً والأمان (r)

$$
\begin{aligned}
& \text { (1) دماء علي أستار الكعبة : صـ }
\end{aligned}
$$

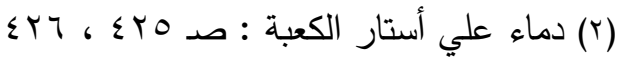

$$
\begin{aligned}
& \text { (r) دماء علي أستار الكعبة : صـ } 9 \text { (بـ }
\end{aligned}
$$




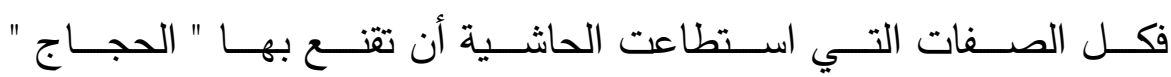

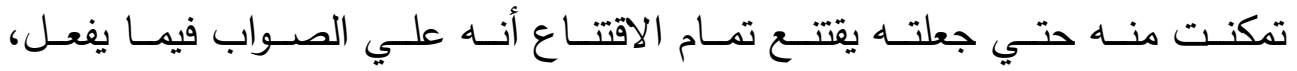

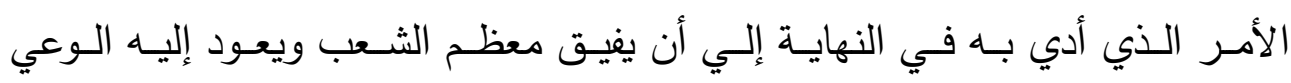

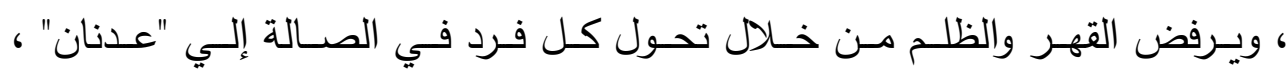

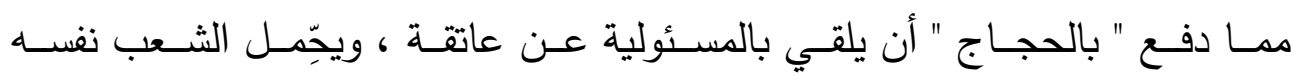
مسئولية تحوله إلي هذه الصورة . الحجاج : القهر فيكم ليس في حكاكم ... فأنا الإله صنعتموني بينكم وعبدتموني ... ثم جئتم ترجمون إلهكم سيجيء بعدي ألف حجاج جديد. (1)

: -

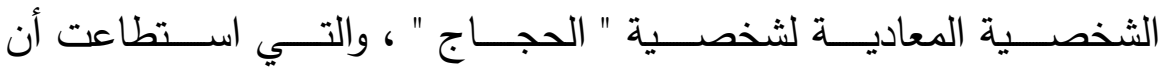

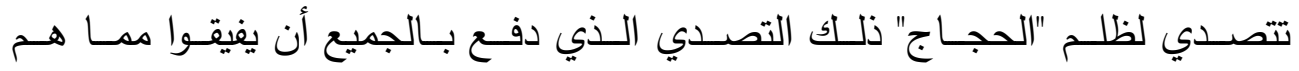

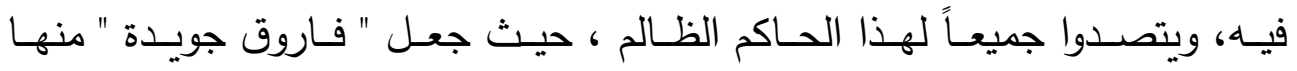

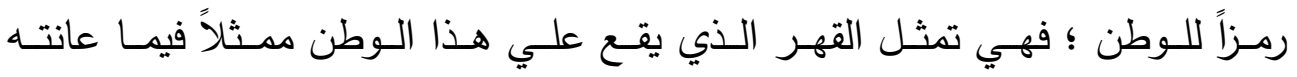

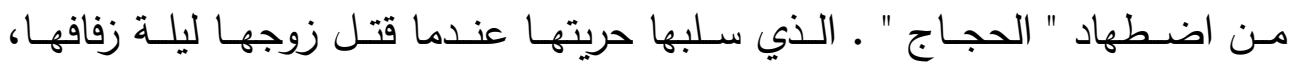

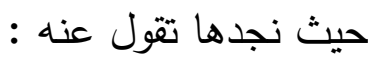
سعاد : عدنان في عمري رجاء (r)

$$
\begin{aligned}
& \text { عدنان في قلبي صباح لا يغيب. } \\
& \text { (1) دماء علي أستار الكعبة : صـ (1) } \\
& \text { (r) دماء علي أستار الكعبة : صـ TVA }
\end{aligned}
$$


" فسعاد " تري أن الأوطان صارت سجوناً واسعة في ظل هذا الحكم الظالم

$$
\text { سعاد : أوطاننا صارت سجوناً واسعة }
$$

والسجن سجن أينما كان

الناس تعشق عمرها في الطين حين يجود

في الماء حين يفيض. (1)

لـذا تـري " سـعاد " أن " عـدنان " هـو المنقـذ الـذي سـيجيء ويخلـص المجتهـع

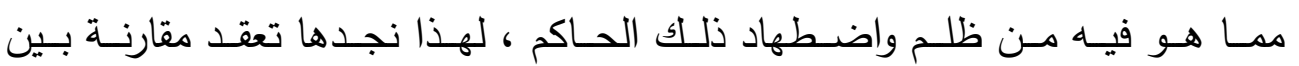

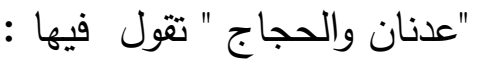
سعاد : عدنان ... والحجاج

عدنان طهر في زمان المعصية ..

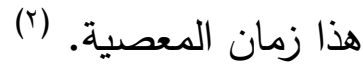

ونظـراً لتمسكها " بعدنان " وانتظـار قدومـهـ إليها ، نجدها تعلـن أمسام الجميـع أنهـا

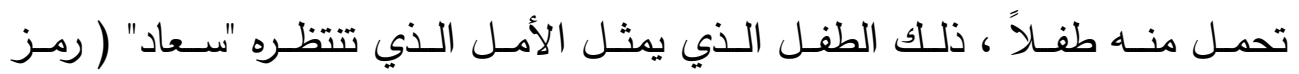
الوطن ) والذي سيخلصها مما هي فيه وينقذ الوطن من هذا الظلم . سعاد : عدنان زوجي ... وهناك طفل بين أحشائي سيولد ذات يوم

$$
\begin{aligned}
& \text { إني حملتك في ضميري بين أحضاني } \\
& \text { وفي عيني ضياء }
\end{aligned}
$$

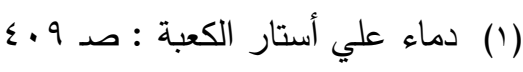

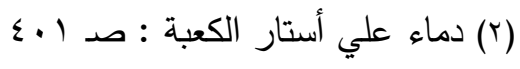


وليس في يدنا الخلاص (')

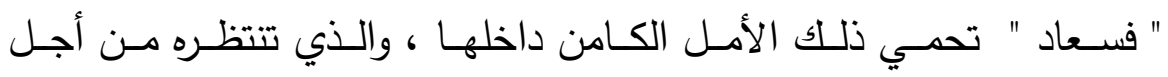

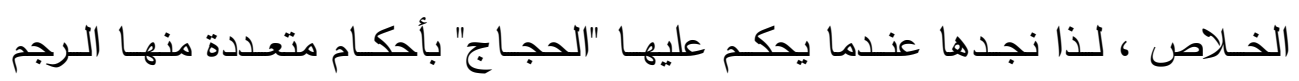

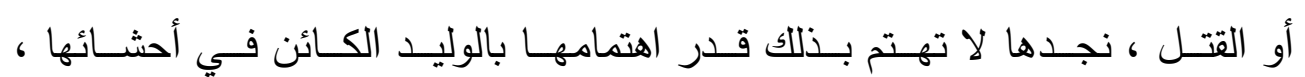
حيث تصرخ وتطلب منهم ألا يقتلوه داخلها . سعاد : " تطوف علي المسرح " لا تقتلوه لا تقتلوا الأمل الوليد فقد ظللت العمر

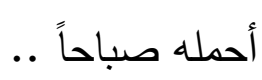

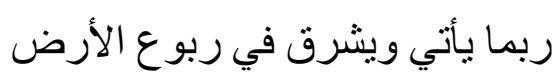
بالزمن النقي.

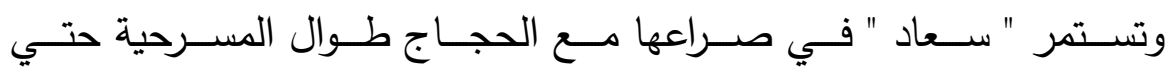

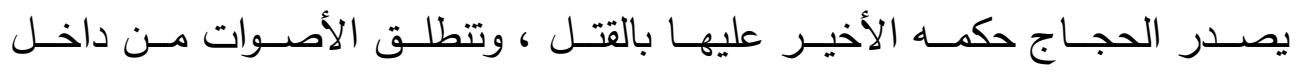

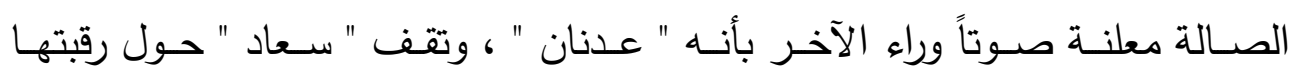

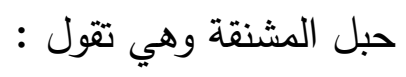
سعاد : كل الحياة إلي زوال حكامها .... تيجانها .... ألقابها فالناس تمضي ... أو تجىء والعمر يرحل لا يجىء

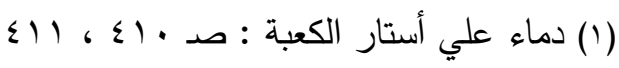

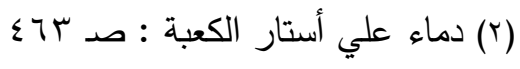




$$
\begin{aligned}
& \text { لكن أعظم ما يراه الناس فوق الأرض .. } \\
& \text { إنسان أقام العدل فى زمن الضلال } \\
& \text { فالعدل فى زمن السلاسل والقيود }
\end{aligned}
$$

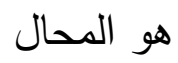

$$
\begin{aligned}
& \text { إنسان يرى أن الحرام هو الحرام } \\
& \text { أن الحلال هو الحلال }
\end{aligned}
$$

أن الشعوب أمانة لله فى عنق الرجال

فرق كبير بين شعب فى يد الشرفاء ...

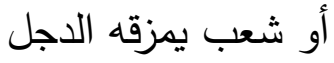

فرق كبير بين من نهب الشعوب ...

وبين آخر قد عدل

$$
\text { هذا هو الإنسان يا حجاج }
$$

$$
\text { إنسان .... عدل }
$$$$
\text { إنسان ... عدل }
$$

إنسان ...عدل . (1)

\section{: بلام - بلام}

مـن الشخصـيات المهمـة داخـل المسـرحية ، والتـى اسـتطعنا مـن خلالهـا أن نتعـرف على بـاقي الشخصـيات داخـل العمـل المسـرحى ، فهـو الـذى أخبرنـا OVV ، OVT (1) دماء علي أستار الكعبة : صـ 


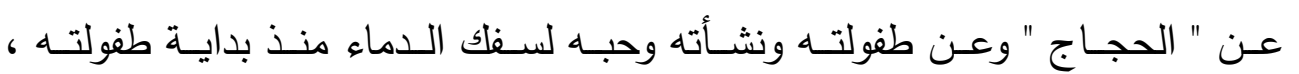

وأنه أصبح فيما بعد رجل شرٍ وسفلك دماء .

سلام : سألوه من أحببت يا حجاج

فأجاب : ما أحببت شيئاً فى حياتى

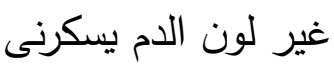

كأقداح النبيذ ...... - (

سعيد : أكمل لنا ..... أكمل

سلام : رفض الرضاعة ذات يوم فى المساء حملته أمه .....

ذهبت إلى العراف تسأله : لماذا يرفض الطفل

الصغير غذاء أمه ؟ - (أس

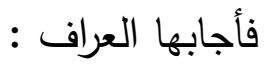

هيا اذبحي شاة صغيرة ....

واسقيه دم الشاة ..... -

ثم اذبحي للطفل عند الفجر حية ...

واسقيه دم الحية السوداء

ولطخى وجه الصغير ببعض هذا الدم 
سلام : سألته الأم : لماذا يشرب هذا الدم ؟

قال العراف : طفلك سيعيش يحب الدم. (')

وقـد أخبرنـا " سـلام " أيضـاً فـى بدايـة المسـرحية عـن علاقـة " الحجــاج "

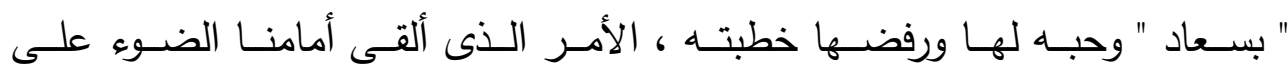

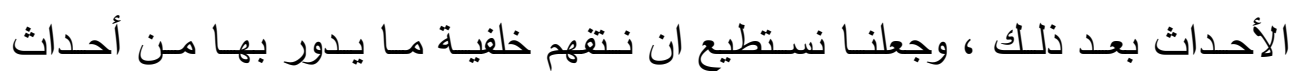
حتى يتســى لنـا أن نفهم ترتيـب الحـدث وتصــاعد الصـراع داخـل المسـرحية . فلـولا وجـود "سـلام" فـى المسـرحية لمـا اسـتطعنا أن نـتفهم الكثيـر مـن الأحـداث التـى تـدور بهـا ، لـذا فإنتـا نعتبـره مـن الشخصـيات الهامــة والمـؤثرة داخـل العمـل

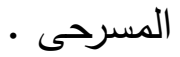

لذا يمكن القول أن " فاروق جويدة " استطاع فى مسرحية " دماء على أستار الكعبة " أن يختار مجموعة من الشخصيات التى تجسد الواقع التاريخى الذى أراد أن يصوره لنا

وقـد تمكنــت تلـك الشخصـيات مـن نقـل الرؤيـة التـى أرادهــا الكاتـب مـن وراء هـذا العمـل والتـى تتمثل فـى ضـرورة رفض الظلـم والتصـدي لـه مـن أجـل

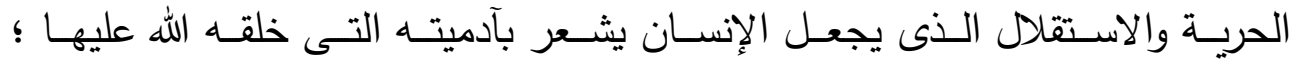
لأن الثـعوب هـى التـى تصـنع الطغـاة ، وتسـمح بوجـود الظلـم ، وتمهـد الأرض

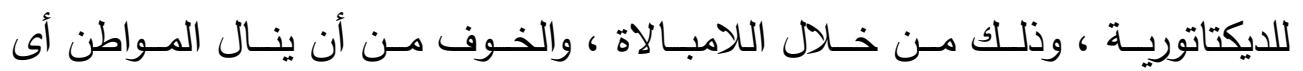
شـر مـن قبـل السـلطة الحاكمـة ، وأيضـاً مـن خـلال الرضــا بمـا يقولـه ذلــ الحـاكم

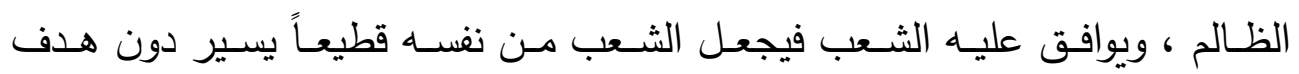
حسب ما يوجهه إليه ذللك الحاكم . 


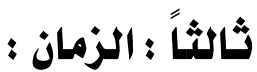

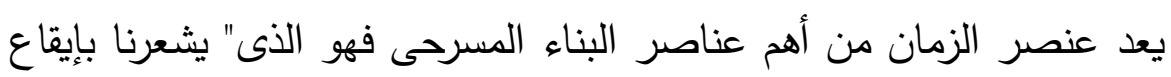

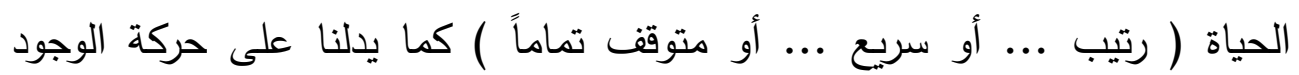

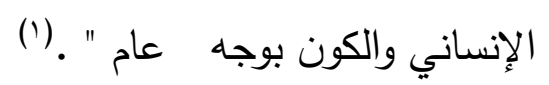

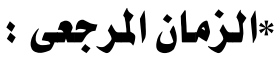

دارت أحداث المسرحية أثناء فترة حكم الحجاج ، حينما كان حاكماً للمسلمين ، وقد استغرقت أحداث المسرحية فترة طويلة من الزمن والتى جعل منها الكاتب زمناً

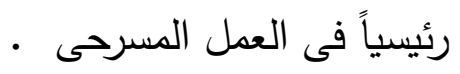

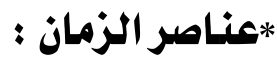

أما بالنسبة للعناصر التى اعتمد عليها " فاروق جويدة " فى المسرحية فإننا

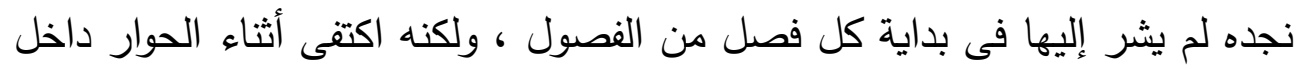
المسرحية بالإثارة إلى وقت الفجر وكذلك وقت المساء ـ فعندما كانت "سعاد" تتحدث

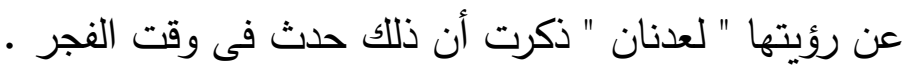
سعاد : ne تدور سعاد حول نفسها .....

(1) عبير صلاح الدين: الزمن بين الفلسفة والفن ( مسرح تثيكوف نموذجا ).الهيئة العامة للكتاب.

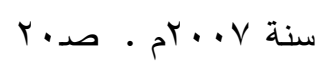




\section{أتى عدنان يوم العرس عند الفجر. (')}

أما عندما كان " الحجاج " يسأل الشهود حول رؤيتهم " لعدنان " فإننا نجد " سليم " يشير إلى الليل الذى تظهر فيه كل أشباح المخاوف . سليم : فى ليلة كان الشتاء يدق أبواب البيوت والليل ينسج خلف جدران المدينة كل أشباح المخاوف والظنون والجند والبوليس فى كل الشوارع ...

يعبثون ... ويقتلون ... ويحرقون (r)

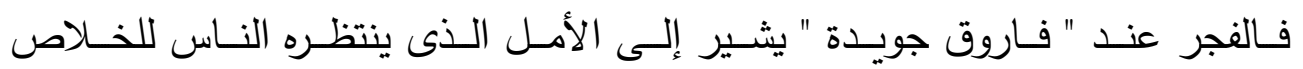

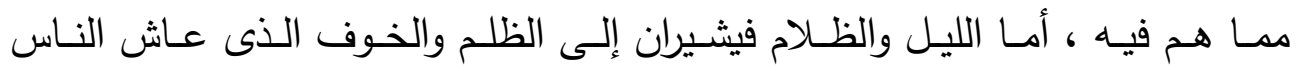
فيـه فـى زمـن " الحجـاج " لـذا نجـد أن الحـديث مـع الحجــاج " أو حـول " الحجــاج " فـى المسـرحية اقترن بـكر الليـل ، أمـا الحديث عـن " عدنان " فقد اقترن بـكر

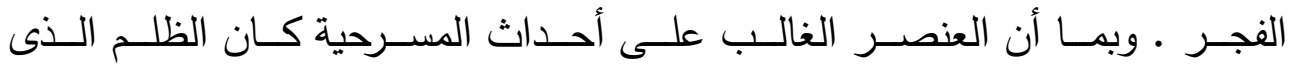
عـاش فيـه النـاس ، فقـد جـاء وصـف الـزمن فـى هـذه المسـرحية بصـفات سـيئة

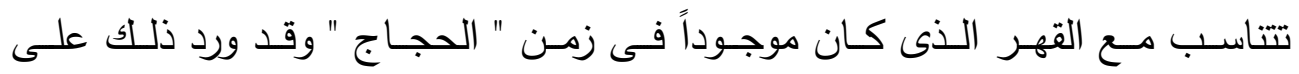

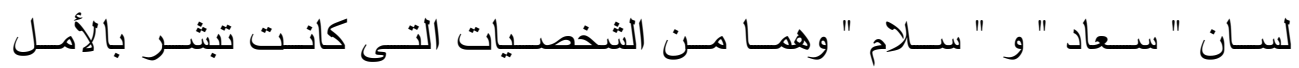
وتتنظر الخلاص من ذلك الزمن الذى وصفوه بما يلى : سلام : قد جاءنا الحجاج يبغى حكمنا .. هذا زمان القهر والبطش الثديد. (')

$$
\begin{aligned}
& \text { (1) دماء علي أستار الكعبة : صدء إع (1) }
\end{aligned}
$$

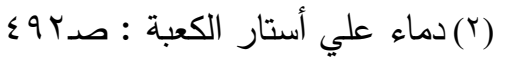


زمن طويل أنت ... يا زمن النفاق

زمن عجيب أنت يا زمناً يعيش على النفاق. (؟)

سعاد : - ( )

عدنان طهر فى زمان المعصية

هذا زمان المعصية ـ (r)

سعاد : هذا زمان الجهل .... والجهلاء

جعل النفاق قلادة السفهاء(")

سلام : آه من الزمن الذى لا عدل فيه

آه من الزمن الذى لا طهر فيه. (0)

وخلاصــة القــول : أن مـــا أورده " فــاروق جويــدة " مــن عنصــرين فتــــــن

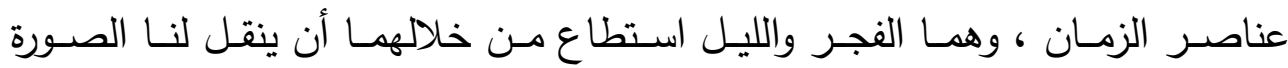
بوضـوح ، وأن يعبـر عـن الظلـم فـى وقـت الليـل ، ويعبـر عـن الأمـل والخـلاص فـى وقـت الفجر مدـثلاً فـى شخصـية عـدنان المنتظـر الـذى سـيخلص الثـعب مدا هو فيه رابعاً : المكاز :

$$
\begin{aligned}
& \text { (1) دماء علي أستار الكعبة : صدمبr } \\
& \text { (r) دماء علي أستار الكعبة : صد... (r) }
\end{aligned}
$$

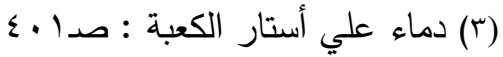

$$
\begin{aligned}
& \text { (ع) دماء علي أستار الكعبة : صدسبع } \\
& \text { (0) دماء علي أستار الكعبة : صدمبه }
\end{aligned}
$$


لم يشر " فاروق جويدة " إلى المكان الرئيسى فى المسرحية ، ولكن يفهم من

الحدث التاريخى ، والشخصية التى يتتاولها وهى شخصية " الحجاج " أن المكان الرئيسى هو مقر حكم الدولة الإسلامية فى عهد " الحجاج " .

\section{:مناصر المكاز :}

تعددت عناصر المكان داخل المسرحية ، فقد دارت الأحداث فى عدة أماكن

هى " الميدان الكبير - مكتب الحجاج - منصـة المحكمة - حجرة المداولة بالمحكمة

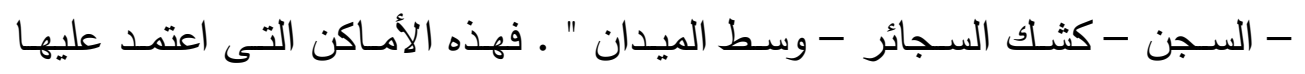
الكاتب جاءت متتاسقة مع الأحداث ، كما أن الانتقال بين تلك الأماكن لم يكن من العسير حدوثه على خشبة المسرح ؛ لأن تلك الأمـاكن جميعها داخل المدينـة التى لتى

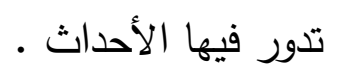

كما أن هذا التعدد فى الأماكن لم يفقد المكان وحدته التى نادي بها نقاد المسرح لأن هذا التعدد فى الأماكن ضروري لخدمة سير الحدث داخل المسرحية . أمـا بالنسـبة لوصـف الجامـد والمتحرك فـى المكـان ، نلاحظ أن الكاتـب أهمـل هـذا الوصف ما عدا وصف المكان فى بداية الفصل الأول من القسم الأول . " الناس يجتمعون فى ميدان كبير بينما تبدو أنقاض وبقايا المعارك والحجارة والأسلحة

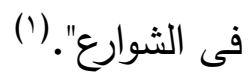
هذا الوصف الذى يعكس لنا الحالة السيئة التى كان عليها المجتمع أثناء فترة حكم "

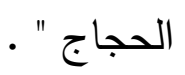

(1) دماء علي أستار الكعبة : صدمبr 
وقد اهتم " فاروق جويدة " بوصف الأشخاص والحالة التى يكونون عليها

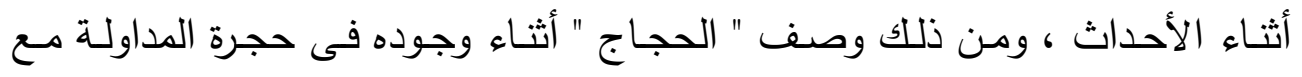

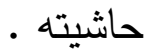

" الحجاج يجلس فى حالة ارتباك فى حجرة الدداولة مع رفيق الأنس وحسب الله وعلاء

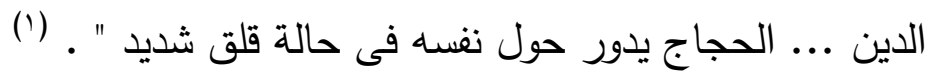
وكذلك وصف" سعاد " أثناء وجودها فى السجن

" سعاد فى سجنها يحيط بها حراس الحجاج يبدو عليها الإرهاق والتعب " . (؟) وأيضاً وصف الناس أثناء وقوفهم فى الميدان لمحاكمة " سعاد " " فى ميدان عام يقف الثعب كله .... والناس فى حالة هلع وخوف وذهول -

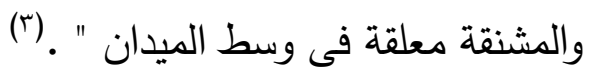

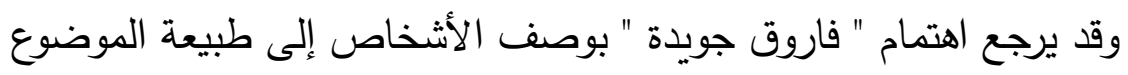

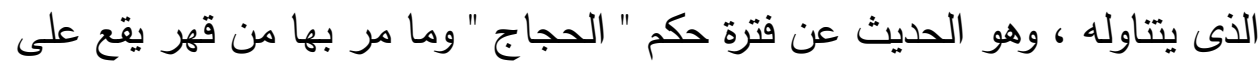

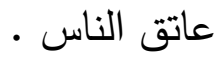
فالكاتب لم يهتم بتفصيلات المكان والزمان قدر اهتمامه بالأشخاص والأحداث التى تلى تدور فيها المسرحية .

\section{خامسا : اللفة والحوار :}

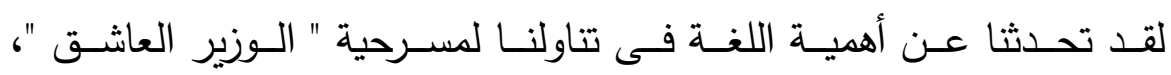

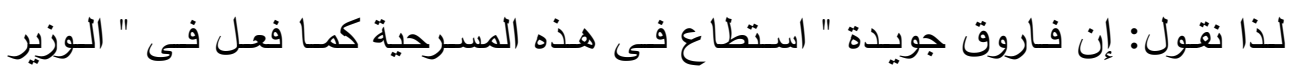

$$
\begin{aligned}
& \text { (ץ) دماء علي أستار الكعبة : صدץ.0 }
\end{aligned}
$$

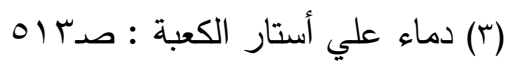

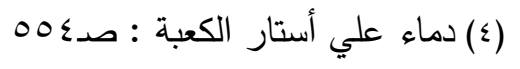




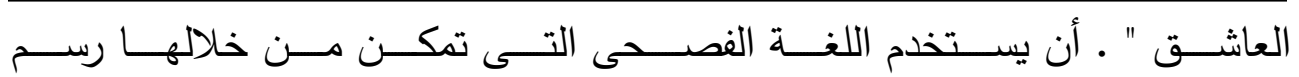

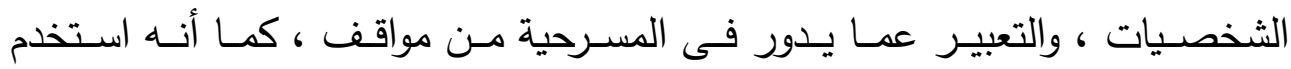

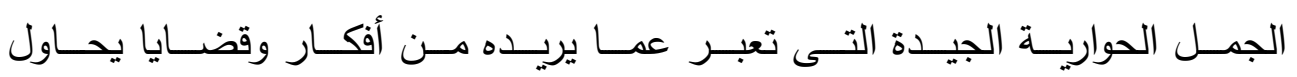

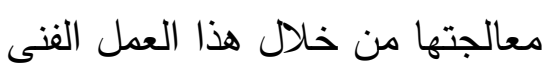

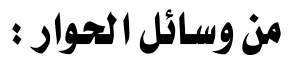

من الوسائل الحوارية التى لجأ إليها الكاتب ما يلى :

1- المونولوج : استخدم " فاروق جويدة " المونولوج الذى استطعنا من خلاله أن

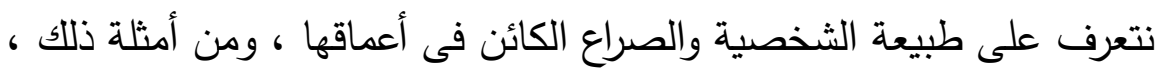
المونولوج الذى دار على لسان " سعاد " حينما كانت تتحدث عن " عدنان " . سعاد : " تكلم نفسها " مازلت أذكر يوم أن رحل العفاف

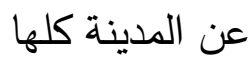
قد كان يلبس ثوبه الفضى .... نفس الثوب ... يخطب فى جموع الناس مازلت أذكر كل شئ فيه

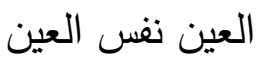
والوجه نفس الوجه ... نفس الحلم 
سعاد : مازلت يا عدنان ضوءاً لا يفارقنى

قد كنت مؤنس وحدتى ... ورفيق دربى (؟)

سعاد : .... العقل يا عدنان غاب

آه من الدنيا غياب ... فى غياب

ما أثقل الأيام يا عدنان بعدك .... (r)

فالمونولوجات التى وردت على لسان " سعاد " توضـح مدى تعلقها " بعدنان " وأنها مازالت تنتظره لأنه الأمل الذى سيخلصها ويخلص المجتمع مما هو فيه من شر " الحجاج " وتسلطه على الناس ؛ لذا فإن ما ورد على لسـان " سعاد " يكشف عما هـ يدور داخلها مـن صـراع ، ويجعل منها شخصية متصـاعدة لا ترضسى بالخضـوع أو الاستسلام ، وإنما ظلت طوال المسرحية تقاوم " الحجاج " وترفض التسليم له كما أراد

أمـا المونولوج الذى ورد على لسـان " الحجـاج " فإنـه يوضـح لنـا طبيعـة تلك

الشخصية التى لا تعرف فى داخلها إلا الكره لجميع من حولها ، ومن أمثلة ذلك :

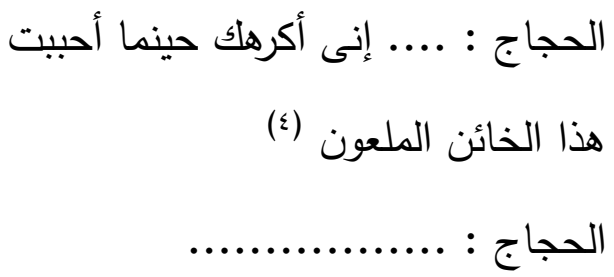

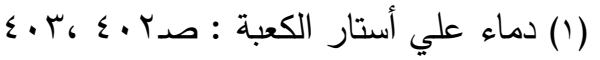

$$
\begin{aligned}
& \text { (ז) دماء على أستار الكعبة : صدץ؟ ؟ }
\end{aligned}
$$

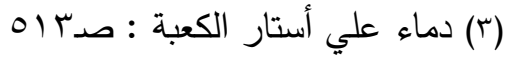

$$
\begin{aligned}
& \text { (1) دماء علي أستار الكعبة : صده؛ ؟ }
\end{aligned}
$$




$$
\begin{aligned}
& \text { عمرى قد ضاع على الضعفاء } \\
& \text { وبدأت صغيراً مثل الناس } \\
& \text { وكنت ضعيفاً كالضعفاء (') } \\
& \text { الحجاج : }
\end{aligned}
$$$$
\text { وإذا قتلت الآن فرداً سوف أضدن }
$$$$
\text { أن يظل الصمت أزماناً يحلق فى مدينتا }
$$$$
\text { ويخرس صوتها (r) (r) () }
$$

فهذه المونولوجات توضح طبيعة الشخصية ، والسياسـة التى يتبعها " الحجاج " فى حكم الناس ، وأن الخوف والجبن هما أفضل طريق لضمان الحكم وسير الناس لا يتكلمون ، إنما يطيعون ما يأمر به ، الأمر الذى يعكس ما عانى منه المجتمع فى هـ تلك الحقبة التاريخية التى حكم فيها " الحجاج " . r الآيات القرآنية : ب

لجأ أيضاً " فاروق جويدة " فى حواره إلى استخدام الآيات القرآنية التى أتى بها على لسـان بعض الشخصيات التى تتحدث لتصبح الشخصية قوية فى الحجة

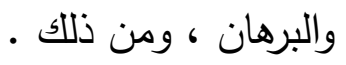
سعاد : :................. قال تعالى " ومن يضلل الله فلن تجد له سبيلاً ".(")

$$
\begin{aligned}
& \text { (ץ) دماء علي أستار الكعبة : صدبی) }
\end{aligned}
$$

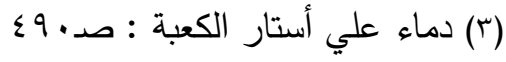

$$
\begin{aligned}
& \text { (1) دماء علي أستار الكعبة : صد؟1ء؟ }
\end{aligned}
$$




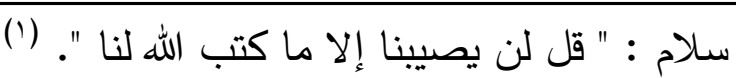

فاستخدام هذه الآيـات على لسـان " سـلام "و " سـعاد " جـاء مناسباً لطبيعـة الشخصية التى تأمل فى الخلاص ، والتى ترى أن ما يحدث للإنسان إنما بفعل من الله عز وجل ، وأنـه يجب على الإنسـان الرضـا بقضـاء الله وقدره حتى تحين اللحظة التى ينتصر فيها الحق ويقضى الله على الباطل .

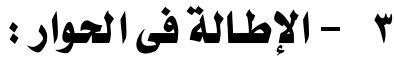

وقد جاء الحوار فى المسرحية يتسم بالإطالة فى بعض المواقف ، الأمر الذى خرج بالحوار فى بعضه عن أهم مميزاته ، لأن هناك صفات يجب توافرها فى الحوار

(ץ) " الدرامي وهى " أن يكون الحوار مركزاً ومشحوناً بالمعاني والدلالات والمشاعر فالحوار " استعداد طبيعى يميل إليه أولئك الذين يميلون إلى الاقتضـاب ـ ذلك أن ألا أعداء الحـوار الإطالـة والحشـ " .(r) وقد ظهر الحـوار الطويـل بصـورة واضـحة فـى إسى المسرحية فى الفصل الثانى من القسم الثانى ، فقد طال الحديث بين " الحجاج "و " الوزراء " فى حجرة المداولة حول طريقة الحكم التى يحكم بها على " سعاد " ، وهو حوار فى حقيقته يكثف عما يدور داخل نفس الحجاج • الحجاج : كثيراً ما أسأل نفسى .... إن كنت أحب ... وماذا يعنى هذا الحب ... شوق ؟ ... فارقنى الشوق ، ولم يرجع

(r) دماء علي أستار الكعبة : صدى إ) (ץ) نبيل راغب : دليل الناقد الأدبى ـ دار غريب للطباعة والنشر ـ القاهرة .

$$
\begin{aligned}
& \text { سنة 1991 م . صد } 94 \\
& \text { (1) توفيق الحكيم : فن الأدب .صد •ــا }
\end{aligned}
$$


سهر ؟ - ما عدت أنام لكى أسهر

حسب الله : مولاى أخطأنا ... تركناها لتحكى كيفما شاءت أمام الشعب رفيق الأنس : صارت بطلة

الحجاج : ماذا أفعل ؟

علاء الدين : يا مولاى تحاكم سراً. (1)

وهكذا يستمر الحوار طوال الفصل الثانى بين " الحجاج " والوزراء " ، وقد كان

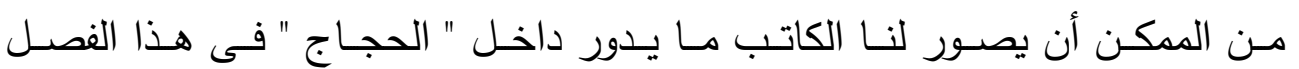
بالمونولوج كما فعل من قبل حتى يكون أكثر تركيزاً وتكثيفاً ، وهو ما يتطلبه الحوار

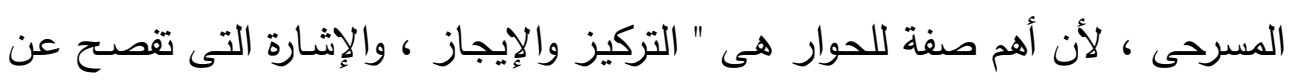
الطبائع ، واللمحة التى توضح الموقف ! .. " (؟) وقد جاء الحوار طويلاً أيضاً فى الفصول التى دار فيها الحوار بين " الحجاج "و " سـعاد " وربما يعود ذلك إلى أن " سعاد " أثناء حوارها مـع " الحجـاج " كانت تتخيل أنها تخاطب " عدنان " فطال بها الحوار دون وعى منها . سعاد : هل بعد هذا العمر يجمعنا مكان ؟ الحجاج : لماذا كلما اقتربت خطانا ...

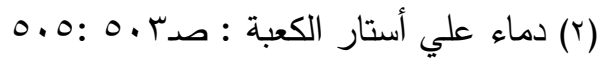

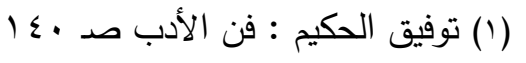




$$
\begin{aligned}
& \text { تعرقنا دروب العدر ؟ } \\
& \text { سعاد : " بصوت خافت " عدنان ؟ } \\
& \text { الحجاج : إنى أحبك يا سعاد } \\
& \text { (1)... سعاد : وأنا ورب الناس لم أعشق سوى عينيل } \\
& \text { ومثل هذا الإطناب فى الحوار أدى إلى حدوث تعانق بين "سعاد" و "الحجاج"، } \\
& \text { الهيام بأفكارها حتى تعانق عدوها اللدود ؟! }
\end{aligned}
$$$$
\text { الأمر الذى يدفعنا بعيدا عن الإقناع العقلي والدرامي ، فكيف يدفعها المؤلف إلى }
$$

وعلى أيـة حـال فـإذا كـان " فـاروق جويـدة " قد أخفق فى استخدامه لبعض

أساليب الحوار إلا أنه استطاع أن يأتي بالحوار فى مجمله ملائهـاً لكل الثخصيات ،

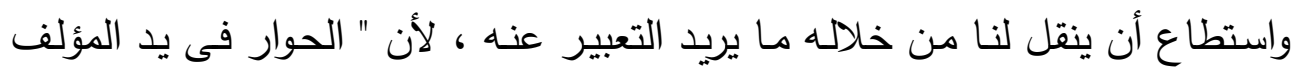
المسرحى ؟ كالريشـة فى يد المصور ، وهى المنوط بها فى الرسم والتلوين والتكوين وكل ما يوضـع على اللوحة من فن!...".(r) كما نجح " فاروق جويدة " فى استخدام الألفاظ المناسبة على ألسنة الثخصيات مما يجعلها قرببة من الواقع المعاش الذى لون عبر عنـه " فـاروق جويـدة " فى هذه المسـرحية ، والتـى يمكن أن نعتبرهـا التطـور لمسرحية " الوزير العاشق " ، فقد نجح من خلال هاتين المسرحيتين أن يصور القهر والفساد ، ويبصر المجتمع بما يمكن أن يحدث له إذا استمر على ما هو عليه من الخضوع والاستسـلام ، وقد كانت براعته أيضـاً فى استخدام المسرح الشعري للتعبير 
عن رؤياه ، ذلك اللون من الأدب الذى يرى نقاد الأدب والمسرح أنه " أغزرها تعبيراً

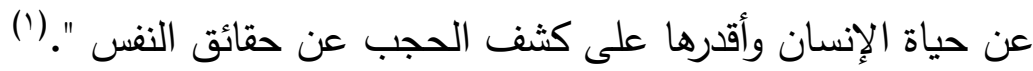

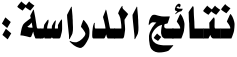

بعد دراسة الموضوع توصل الباحث إلى عدة نتائج يمكن إجمالها فيما يلى:

1-اعتمد "فاروق جويدة" على التاريخ وجعل منه مصدراً لبناء أعماله المسرحية، ولكنه لم ينقل التاريخ كما هو بالفعل، فقد قام بإعادة بنائه وإسقاط الرؤية الحديثة عليه. حيث نجده فى "الوزير العاشق" يوظف قصة الحب الثهيرة بين "ابن زيدون" و "ولادة" التى حدثت فى الأندلس فى حقبة تاريخية من تاريخنا العربى ليعلن احتجاجه على الواقع المرير الذى نعيش فيه، حيث تفتت المجتمع العربى وضاعت الأرض. فالفساد الذى ساعد على ضياع الأندلس وضياع التراث العربى هو ذاته الذى

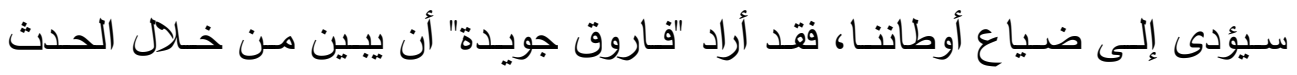

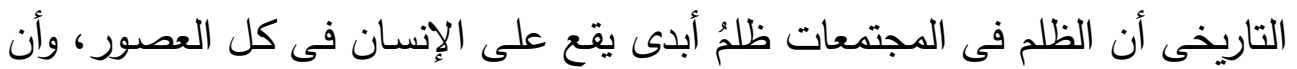
ضياع الاوطان سببه الرئيسى هو ظلم الحكام وفساد الحاشية التى تعاونهم فى الحكم.

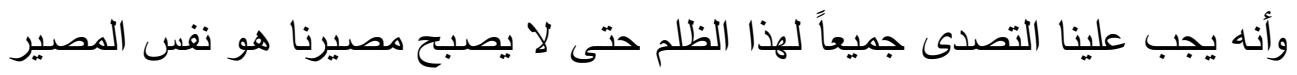

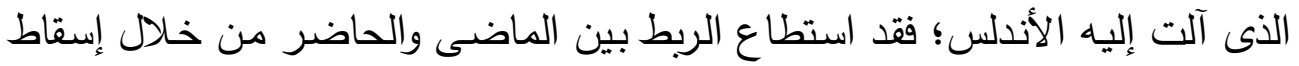
بعض الأحداث التاريخية على واقعنا الذى نعيشه.

$$
\text { (r) (بحا زكى العشماوى : }
$$

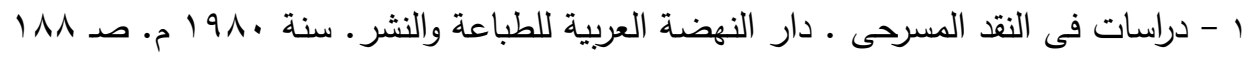

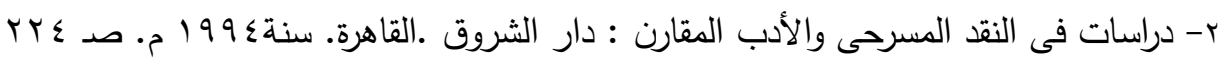


ونجده أيضاً فى "دماء على أستار الكعبة" يناقش نفس القضية حيث استخدم

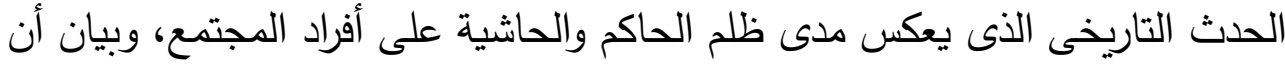

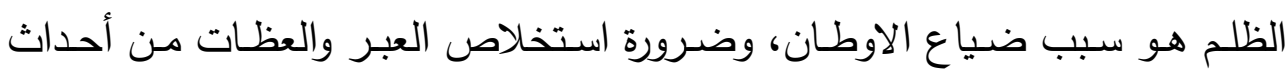
التاريخ حتى نتمكن من الرقى بالمجتمع.

r-استطاع "فاروق جويـدة" أن ينسق شخصياته تتسيقاً جيداً، فقد صسورها جميعاً بصورة تخدم الواقع الذى عبر عنه حيث استخدمها بصورة رمزية معبرة عما يهدف

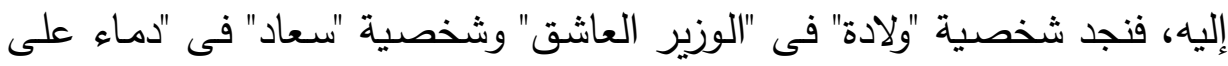
أستار الكعبة" يرمز بهما إلى الوطن.

أما شخصية "الحجاج" فى "دماء على أستار الكعبة" فترمز للظلم والقهر فى كل مكان

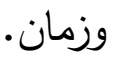

r-لم يلتزم "فاروق جويدة" بوحدة الزمان وذلك تمشياً مع آراء النقاد الذين يطالبون

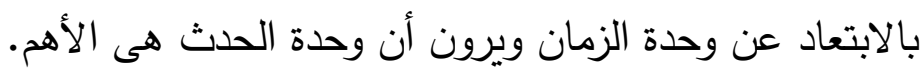
ع-التزم "فاروق جويدة" بوحدة المكان فى "الـوزير العاشق" و "دمـاء على أستار

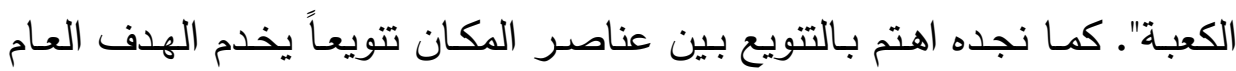

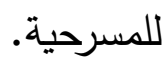

أما بالنسبة لوصف الأماكن فنجد أنه لم يهتم بوصف الجامد والمتحرك داخل العمل

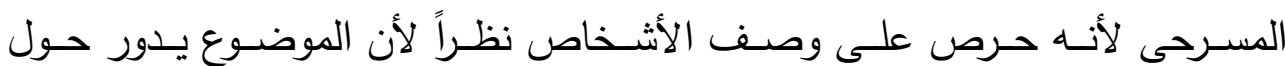

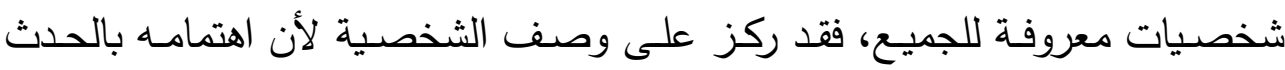
والثخصية كان غالباً على اهتمامه بالمكان. ه-اعتمد "فاروق جويدة" على اللغة الفصحى لأنها أنسب الى الكتابة الثعرية من

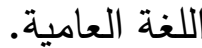


أما بالنسبة للحوار : فقد وظف الحوار لتصوير الشخصيات، كما لعب دوراً حيوياً فى تحريك الأحداث المسرحية. كما نجده قد وظف الصمت فى الحوار لما له من قدرة على التعبير فى المواقف التى يعجر الكلام عن آدائها. 
- دار الشروق/القاهرة ؟ . . ب وأيضاً دار غريب للطباعة/ القاهرة د.ت

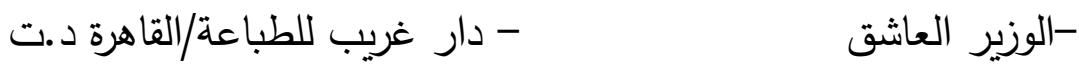
ثانياً : المراجع:

19NV /إبراهيم حمادة: من حصاد الدراما والنقد/ الهيئة العامة للكتاب معم المصطلحات الدرامية والمسرحية/دارالمعارف/ 1910 *أحمد سخسوخ: الدراما الثعرية بين النص والعرض المسرحى. الهيئة المصرية العامه للكتاب/r...

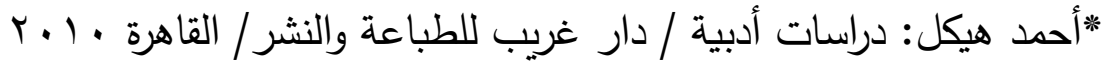
"أمير سلامة: الثخصية والنمط فى الدراما/ مجلة الفنون/السنة الاولى/

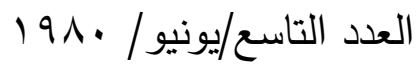
199V/أسامه فرحات: المنولوج بين الدارما والشعر / الهيئة العامة للكتاب " I9VV/ "حسـين على حمحة: البطـل فـى المسـرح الثـعرى المعاصـر /الهيئة العامـة لقصـور

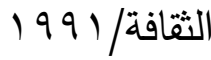


*سـامى منير حسين عـامر : من أسـرار الإبـداع النقدى فى الثـعر والمسرح/ منشـأة

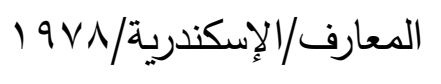

*صـلاح حسـنى عبد العزبـز : عحمد عبد المجيد حلمى كناقـد مسـرحى/الدار القوميـة

$$
\text { للطباعة والنشر/7 } 97
$$

*عبد القادر القط: فى الأدب المصرى المعاصر (دراسـة تطبيقية لمشكلات معاصرة

$$
\text { فى الأدب والثقافة فى مصر ) مكتبة مصر /القاهرة/د.ت }
$$

*عبد المطلب زايـ: أسـاليب رسم الشخصية المسـرحية (قراءة فى مسرحية مصـرع

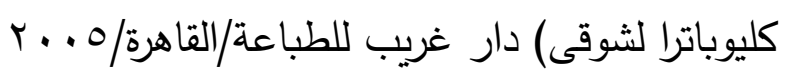

*عبير صـلاح الدين: الزمن بين الفلسفة والفن (مسرح تشيكوف نموذجاً) الهيئة

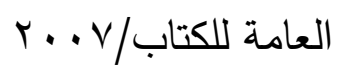

*فرحـان بلبـل: الــص المسـرحى (الكلمــة والفعـل) منشــورات اتحــاد الكتــاب

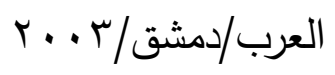

* لاجوس آجرى: فن كتابة المسرحية/ترجمة درينى خشبة/

$$
\text { دار سعاد الصباح/ 1999 }
$$

*ماجـدة مــراد: شخصــياتتا المعاصــرة بــين الواقـع و الــدراما التليفزيونيــة/عالم

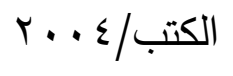

*محـ زكى العشـماوى: - دراسـات فـى النقد المسـرحى/دار النهضــة العربيـة للطباعـة

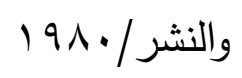

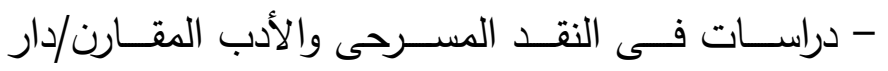

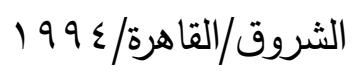




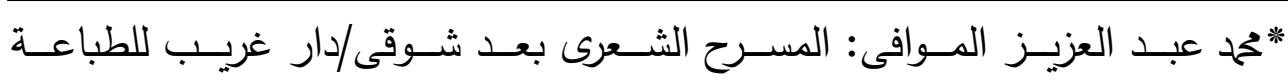

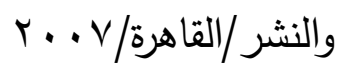

" محمد عنانى: من قضايا الأدب الحديث/الهيئة العامة للكتاب/1990" " أحمد فتوح أحمد: فى المسرح المصرى المعاصر/مطبعة عابدين/ "حمح مندور : -الأدب ومذاهبه/نهضة مصر للطباعة والنشر/ 190 V - المسرح/نهضة مصر للطباعة والنشر/9199

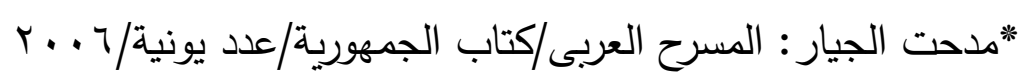

*مصرى عبد الحميد حنورة: الأسس النفسية للإبداع الفنى فى الشعر المسرحى/الهيئة

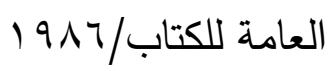

"مصطفى عبد الغنى: المسرح المصرى فى الثمانينات (دراسة فى النص المسرحى

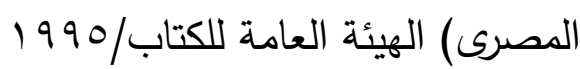

*نبيل راغب: -لغة المسرح عند ألفريد فرج/الهيئة العامة للكتاب/1917

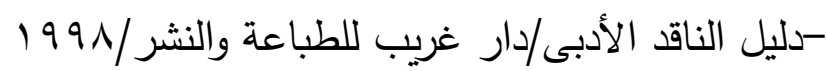

*نهاد صليحة: المسرح بين الفن والفكر/الهيئة العامة للكتاب/1917 *هدى حلمى أبو المجد الجندى: الوطن فى شعر فاروق جويدة (دراسة تحليلية نقدية)

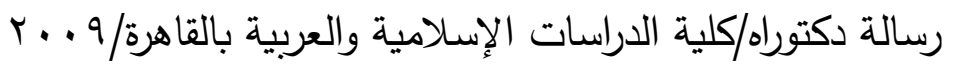

* writing for television and Radio: rober TL . Hilliard $4^{\text {th }}$ ed, California, wads worth publishing company, 1984 